1994

\title{
The Public Interest and the Unconstitutionality of Private Prosecutors
}

John Bessler

University of Baltimore School of Law, jbessler@ubalt.edu

Follow this and additional works at: http://scholarworks.law.ubalt.edu/all_fac

Part of the Constitutional Law Commons, and the Legal Ethics and Professional Responsibility Commons

\section{Recommended Citation}

The Public Interest and the Unconstitutionality of Private Prosecutors, 47 Ark. L. Rev. 511 (1994)

This Article is brought to you for free and open access by the Faculty Scholarship at ScholarWorks@University of Baltimore School of Law. It has been accepted for inclusion in All Faculty Scholarship by an authorized administrator of ScholarWorks@University of Baltimore School of Law. For more information, please contact snolan@ubalt.edu. 


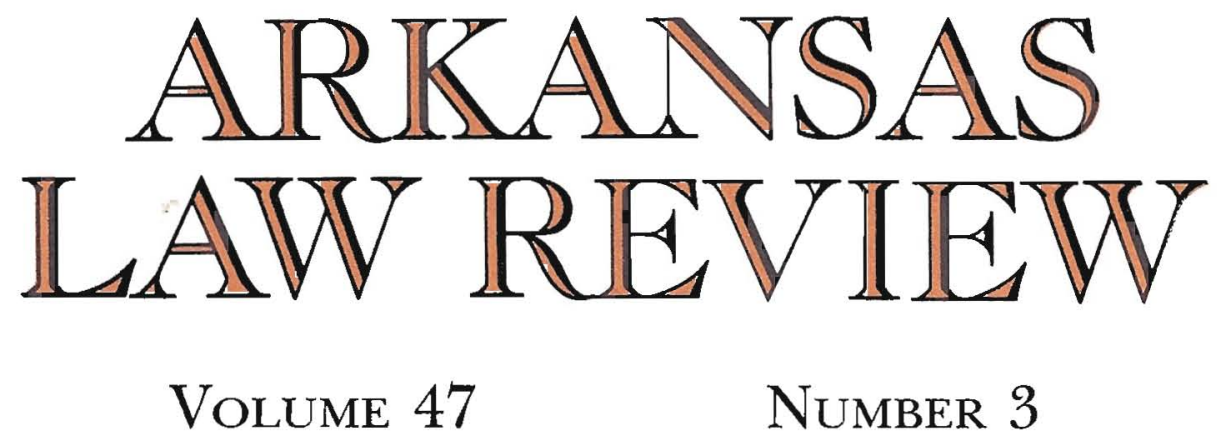

Articles

The Public Interest and the Unconstitutionality of Private Prosecutors John D. Bessler

Are Ideas Within the Traditional Definition of Property?: A Jurisprudential Analysis Andrew Beckerman-Rodau

\section{Case $\mathcal{N}$ Cotes \\ Recent Developments}




\title{
The Public Interest and the Unconstitutionality of Private Prosecutors
}

\author{
John D. Bessler* \\ TABLE OF CONTENTS
}

Introduction ............................. 511

I. History of Private and Public Prosecution ..... 515

II. Young $v$. United States ex rel. Vuitton et Fils

S.A................................... 521

III. Existing Statutes and Case Law............ 529

A. Jurisdictions Allowing Private

Prosecutors ............................ 529

B. Jurisdictions Prohibiting Private

Prosecutors ............................ 540

IV. Prosecutorial Ethics ...................... 543

V. The Unconstitutionality of Private

Prosecutors .............................. 550

A. The Law of Due Process............. 550

B. An Unbiased Judicial System and the

Appearance of Evenhanded Justice....... 553

C. The "Public Interest"................... 558

D. Conviction Reliability and Prosecutorial Accountability....................... 566

E. From "Supervisory Authority" in Young to the Constitutional Preclusion of Private Prosecutors ............................... 571

Conclusion .............................. 597

\section{INTRODUCTION}

In 1987, the United States Supreme Court held, in the exercise of its "supervisory authority," that a district court erred in appointing counsel for an interested party to prosecute a criminal contempt action. In Young $v$. United States

\footnotetext{
* Associate, Faegre \& Benson, Minneapolis, Minnesota, 1991 - present; J.D. 1991, Indiana University School of Law at Bloomington; B.A. 1988, University of Minnesota at Minneapolis.
} 
ex rel. Vuitton et Fils S.A., ${ }^{1}$ the Supreme Court ruled that the appointment of counsel for an interested party created opportunities for conflicts of interest to arise and created at least an appearance of impropriety. ${ }^{2}$ Noting irreconcilable differences in the ethical obligations of public and private advocates, the Supreme Court-refusing to apply "harmless error" analysis-reversed the contempt convictions of several defendants. ${ }^{3}$

Notwithstanding the Supreme Court's pronouncement in Young, several jurisdictions in the United States still allow the use of privately retained prosecutors for interested parties. ${ }^{4}$ These prosecutors are usually employed by victims or their families (or by those interested in collateral civil lawsuits) to assist the district attorney in the criminal proceeding. Although private prosecutors are supposed to remain under the direction and control of the public prosecutor, such prosecutors often play significant roles at trial or during pre-trial activities. At trial, for example, private prosecutors often examine key witnesses, make objections, or conduct opening and closing arguments. ${ }^{5}$

1. 481 U.S. 787 (1987).

2. Id. at 807 .

3. Id. at 813. For an analysis of the Young decision, see Terri L. Braswell, Comment, Criminal Procedure-Young v. United States ex rel. Vuitton et Fils S.A.: The Right to a Disinterested Prosecutor in a Federal Criminal Contempt Proceeding Arising from the Underlying Civil Litigation, 18 MEM. ST. U. L. Rev. 143 (1987) [hereinafter Braswell].

4. See infra notes 71-117 and accompanying text. Unless otherwise noted, the phrase "private prosecutor" will be used to mean a private prosecutor for an interested party. This article only addresses the constitutionality of private prosecutors for interested parties. The use of the term "private prosecutor" should not be confused with state laws that specifically allow disinterested private attorneys to prosecute cases in the absence of a county attorney. See, e.g., MinN. STat. $\$ 388.09$ (Supp. 1993); Keiver v. Koochiching County, 169 N.W. 254 (Minn. 1918) ("When there is no county attorney, the county board may employ any competent attorney to perform legal services for the county.").

5. See infra notes 76-89 and accompanying text. Notably, some state statutes specifically require public prosecutors to conduct certain trial activities. Compare TENN. CODE ANN. \& 8-7-401 (1988) ("The district attorney general or his deputies [sic] shall make the final and concluding argument.") with State v. Bennett, 798 S.W.2d 783, 786 (Tenn. Crim. App. 1990) (Section 8-7-401 of the Tennessee Code "does not prohibit a private prosecutor from making the opening argument to the jury. Only the rebuttal, or last argument, must be made by the district attorney general or his assistant."). 
In general, the post-Young cases allowing the use of private prosecutors have either ignored the Young decision, ${ }^{6}$ distinguished Young as a "supervisory authority" case, ${ }^{7}$ or held that Young merely precludes private prosecutors from taking complete or effective control of criminal prosecutions. $^{8}$ One pending habeas corpus case is challenging the use of two private prosecutors, hired by a murder victim's son, where the death penalty was ultimately imposed. ${ }^{9}$ Because prosecutors have nearly unbridled discre-

6. See State v. Camacho, 406 S.E.2d 868, 871 (N.C. 1991) (no citation to Young); State v. Woodruff, 392 S.E.2d 434 (N.C. App. 1990), aff'd, 399 S.E.2d 114 (N.C. 1991) (per curiam) (same); State v. Bennett, 798 S.W.2d 783, 785-86 (Tenn. Crim. App. 1990) (same); State v. Dunbar, 566 A.2d 970 (Vt. 1989) (same); $c f$. Dick v. Scroggy, 882 F.2d 192 (6th Cir. 1989) (no citation to Young in the majority opinion); Hughes v. Bowers, 711 F. Supp. 1574, 1583 (N.D. Ga. 1989), aff'd, 896 F.2d 558 (11th Cir. 1990) (Without citing Young, the court held that "[t]he presence of a special prosecutor hired by the family of the victim is not constitutionally improper per se."); Kerns v. Wolverton, 381 S.E.2d 258, 262 (W. Va. 1989) (Without citing Young, the West Virginia Supreme Court stated in dicta that "this Court has countenanced the participation of a private prosecutor at trial.").

7. Dick v. Scroggy, 882 F.2d 192, 198 n.2 (6th Cir. 1989) (Celebrezze, J., concurring); New Jersey v. Imperiale, 773 F. Supp. 747, 752 (D. N.J. 1991); New Jersey v. Kinder, 701 F. Supp. 486, 490 \& n.6 (D. N.J. 1988); Commonwealth v. Hubbard, 777 S.W.2d 882, 883 (Ky. 1989). See Sassower v. Sheriff of Westchester County, 824 F.2d 184, 191 (2d Cir. 1987) (Young distinguished on the ground that no pretrial investigation or other prosecutorial conduct was required in order to make a criminal contempt determination; a private party's motion for criminal contempt "simply concerns the routine New York State practice of bringing contempts to the attention of the court by motion," and the criminal contempt conviction was enforceable "because the court already had before it all the facts needed to establish Sassower's commission of the multiple contempts" [i.e., failure to make a required appearance]); see also Ex parte Williams, 799 S.W.2d 304, 307 n.10 (Tex. Crim. App. 1990) (Noting that Young was decided pursuant to the Supreme Court's "supervisory powers," the court stated that "[w]e have found nothing in our rules of procedure or prior case law which requires that prosecution of criminal contempt arising out of Texas civil suits be deemed a separate proceeding from that suit, or be brought on behalf of the State."). It is well-established that Supreme Court decisions based on the Court's supervisory authority over federal courts are not binding on the states. Smith v. Phillips, 455 U.S. 209, 221 (1982).

8. Person v. Miller, 854 F.2d 656, 663 (4th Cir. 1988).

9. Joseph Stanley Faulder v. James Collins, Case No. 6:92-CV-755 (E.D. Tex.) (Brief in Support of Petitioner's Proposed Conclusions of Law, Jan. 1994; Petitioner's Proposed Findings of Fact and Conclusions of Law, Jan. 1994) (copies on file with The Arkansas Law Review); see also Powers v. Hauck, 399 F.2d 322 (5th Cir. 1968) (approving the use of a private prosecutor where the death penalty was imposed).

In Faulder, two private prosecutors were paid approximately $\$ 90,000$ to prosecute the defendant. Although a public prosecutor was assigned to work on the case 
tion with respect to the criminal process, this Article addresses the question of whether the Supreme Court's decision in Young merely foreshadows a constitutional preclusion of private prosecutors for interested parties.

In addressing this question, Part I of this Article discusses the history of private and public prosecution in the United States. The Supreme Court's decision in Young is the focus of Part II, while Part III discusses existing statutory provisions and case law. In Part IV, the standards regulating prosecutorial ethics are outlined, with Part V analyzing the constitutionality of the use of private prosecutors. Ultimately, this Article concludes that the use of private prosecutors is unethical and violative of a defendant's constitutional rights. In particular, this Article asserts that the use of such prosecutors violates the due process guarantee and creates, at the very least, an unacceptable appearance of impropriety.

In reaching this conclusion, this Article also asserts that the use of private prosecutors violates the "public interest"-what Justice Felix Frankfurter once called "that vague, impalpable, but all-controlling consideration." 10 While public interest considerations are normally reserved for legislatures, this Article argues that a "public interest" analysis, which is appropriate because of a prosecutor's obligation to serve the "public interest," provides an additional theoretical basis for declaring unconstitutional the use of private prosecutors under due process principles. Thus, this Article concludes that the public's interest in not having its members erroneously charged or convicted in the

in Faulder, his involvement was limited to jury selection, where he questioned some prospective jurors. During trial, however, the public prosecutor examined no witnesses, made no objections, and made no arguments to the jury. Indeed, his only contact with the jury was reading into the record the testimony of a deceased hearsay declarant. The public prosecutor even took one afternoon off during trial to play golf. Although Young was decided before Faulder's conviction was affirmed by the Texas Court of Criminal Appeals, the private prosecutor issue was not addressed on direct appeal. Faulder v. State, 745 S.W.2d 327 (Tex. Crim. App. 1987).

Another pending habeas corpus case in Texas is also challenging the use of a private prosecutor where a death sentence was imposed. Telephone interview with Sandra Babcock, Texas Resource Center (Mar. 8, 1994) (discussing Wayne East v. James Collins, Case No. 1:92-CV-087-C (N.D. Tex)).

10. Felix Frankfurter, Felix Frankfurter Reminisces 72 (1960). 
criminal process outweighs an interested party's right to retain a private prosecutor.

\section{HISTORY OF PRIVATE AND PUBLIC PROSECUTION}

Several scholars have attempted to trace the historical origins of private prosecution in the United States. ${ }^{11}$ Without exception, these scholars have determined that the notion of private prosecutions originated in early common law England, where the legal system primarily relied upon the victim or the victim's relatives or friends to bring a criminal to justice. ${ }^{12}$ According to these historians, private prosecutions developed in England as a means of facilitating private vengeance. ${ }^{13}$ Although two English public authorities,

11. See 3 ENCYClopedia of CRIME ANd Justice 1286-88 (Sanford H. Kadish ed. 1983); Joan E. Jacoby, The American Prosecutor: A Search for Identity 3-39 (1980) [hereinafter Jacoby]; Allen Steinberg, The Transformation of Criminal Justice: Philadelphia, 1800-1880 (1989) [hereinafter Steingerg]; Juan Cardenas, The Crime Victim in the Prosecutorial Process, 9 HARv. J.L. \& PuB. PoL'y 357, 359-71 (1986) [hereinafter Cardenas]; Josephine Gittler, Expanding the Role of the Victim in a Criminal Action, 11 Pepperdine L. Rev. 117, 125-32 (1984) [hereinafter Gittler]; Harold J. Krent, Executive Control Over Criminal Law Enforcement: Some Lessons From History, 38 AM. U. L. REv. 275, 290-96 (1989) [hereinafter Krent]; Joan Meier, The "Right" to a Disinterested Prosecutor of Criminal Contempt: Unpacking Public and Private Interests, 70 WASH. U. L.Q. 85, 101-03 (1992) [hereinafter Meier]; Thomas J. Robinson, Comment, Private Prosecution in Criminal Cases, 4 WAKe Forest L. Rev. 300 (1968) [hereinafter Robinson]; Andrew Sidman, Comment, The Outmoded Concept of Private Prosecution, 25 AM. U.L. Rev. 754, 756-65 (1976) [hereinafter Sidman]; W. Scott Van Alstyne, Jr., Comment, The District Attorney-A Historical Puzzle, 1952 WIs. L. Rev. 125 [hereinafter Van Alstyne].

12. Sidman, supra note 11 , at 756 ; Robinson, supra note 11 , at 302 ; see also Sidman, supra note 11, at 758-59 (English law explicitly allowed a person to prosecute crimes committed upon others); Robinson, supra note 11, at 302 (same); Sidman, supra note 11, at $759 \mathrm{n.35}$ (the charging party bore the cost of a criminal prosecution in England until 1908, when courts were empowered by law to order that the reasonable costs of a prosecution be repaid to the private litigant out of public funds). Notably, even in nineteenth-century America, in places such as Philadelphia, it was often not required that the aggrieved party be the one to prosecute. See generally STEINBERG, supra note 11, at 46, 66 .

13. Sidman, supra note 11 , at 756 ; Meier, supra note 11 , at 102 . According to an early British historian, Sir James Stephen:

The fact that the private vengeance of the person wronged by a crime was the principal source to which men trusted for the administration of justice in early times is one of the most characteristic circumstances connected with English criminal law, and has had much to do with the development of 
the Director of Public Prosecutions and the Attorney General, have placed severe limitations on the ability of private citizens to prosecute criminal actions, ${ }^{14}$ British citizens today maintain the right to institute criminal proceedings. ${ }^{15}$

In the United States, public prosecutions began to replace the system of private prosecutions long before the colonies gained their independence. ${ }^{16}$ For example, in 1643, Virginia established the office of Attorney General. ${ }^{17}$ Patterned largely after its English counterpart, this office allowed the Attorney General to initiate prosecutions of special importance to the Crown. ${ }^{18}$ Although Connecticut was the first colony to enact a statute specifically providing for a system of local public prosecution, ${ }^{19}$ Virginia established a formal system of county prosecuting attorneys in 1711. ${ }^{20}$ Dutch settlements in the American colonies, including settlements in Connecticut, New York, New Jersey,

what may perhaps be regarded as its principal distinctive peculiarity, namely the degree to which a criminal trial resembles a private litigation.

Sir James Stephen, A History of the Criminal Law of England 245 (1883). For a detailed history of private prosecutions in England, see Cardenas, supra note 11 , at 359-66.

14. Sidman, supra note 11, at 756 . The English Parliament established the Office of Director of Public Prosecutions in 1879 by passing the Prosecution of Offenses Act. Sidman, supra note 11, at 760; Robinson, supra note 11, at 301. The Director of Public Prosecutions was to be under the supervision of the Attorney General. Cardenas, supra note 11, at 361. The Office of Director of Public Prosecutions exists to the present in England. Cardenas, supra note 11, at 361. Notably, in the nineteenth century, British reformers, including Jeremy Bentham and Sir Robert Peel, argued that the system of private prosecutions was breeding unacceptable evils. Among those evils was the initiation of prosecutions for revenge and personal animosity and arrangements between attorneys and police to secure prosecutions. Cardenas, supra note 11, at 362.

15. Sidman, supra note 11 , at 756 .

16. Sidman, supra note 11 , at 762 .

17. Sidman, supra note 11 , at 763 .

18. Cardenas, supra note 11 , at 369 .

19. Sidman, supra note 11 , at 763 . Connecticut's statute providing for a system of local public prosecution was enacted in 1704 . Sidman, supra note 11, at 763; Robinson, supra note 11 , at 308.

20. Sidman, supra note 11 , at 763 ; Robinson, supra note 11 , at 309 . At this time, the Virginia Attorney General appointed deputies to each county in the state to prosecute both important and routine cases. Private prosecutions became even less common in 1751, when the Virginia courts forced all crime victims to consult with the deputy attorney general before filing criminal complaints. The deputy attorney generals assumed complete control over all prosecutions within their respective counties in 1789. Cardenas, supra note 11, at 370. 
Pennsylvania, and Delaware, often had the services of a scout, a figure akin to a sheriff and public prosecutor. ${ }^{21}$

While the origin of the American public prosecutor remains an "historical enigma," 22 academics generally trace the roots of this figure to one of three European antecedents: the English, the Dutch, or the French. ${ }^{23}$ Moreover, despite the fact that the American public prosecutor has something in common with each of these predecessors, it is undisputed that the American prosecutor has "powers and discretion" that are "vastly greater than those of any European prosecutor." 24 The importance of the office of public prosecutor in the United States was further reinforced by its shift in the nineteenth century from an appointive office to an elective office. ${ }^{25}$

21. Cardenas, supra note 11, at 370. "When the English took over Dutch settlements in the Seventeenth Century, the English governor revoked all Dutch law and government-except for the scout, who eventually took control of prosecutorial power." Id. (citing Robinson, supra note 11, at 308). According to one scholar: "The scout was a combination sheriff, public prosecutor and financial agent for the Dutch West India Company." Robinson, supra note 11, at 308. For experiences of other colonies with respect to the growth of the public prosecutor, see Gittler, supra note 11, at $126 \mathrm{n} .31$ (listing citations for the colonies of New York, New Hampshire, Maryland, and Rhode Island).

22. Gittler, supra note 11 , at 127.

23. See JACOBY, supra note 11 , at 3 ; Sidman, supra note 11 , at 763 . These influences include the Dutch scout, the English Attorney General or Justice of the Peace, or the French advocate general, procurer publique or procurer du roi. See JACOBY, supra note 11, at 3; Gittler, supra note 11, at 127-129 \& n.34.

24. JACOBY, supra note 11 , at 3 . According to one scholar:

Although the local American prosecutor shares characteristics with all three of [its] European officers, he is very different in many respects. He has the power, like the procurer, to initiate all public prosecutions; he is a local official of regional government like the scout; he has the power to terminate all criminal prosecutions like the Attorney General. Yet, his powers and discretion are vastly greater than those of any European prosecutor. The American prosecutor enjoys an independence and discretionary privileges unmatched in the world.

JACOBY, supra note 11 , at 3 .

25. JACOBY, supra note 11 , at 37-38. According to Joan Jacoby:

After Andrew Jackson was elected in 1828, the expansion of democracy in the form of elected positions swept the country. Hanging on the coattails of the movement to elect local judges was the prosecutor. In 1832, Mississippi became the first state to include in its constitution a provision for the popular election of local district attorneys. By 1859 the trend was clear and irreversible-the prosecutor was a locally elected position.

JACOBY, supra note 11, at 37-38. At present, county attorneys continue to be elected officials. E.g., MinN. Stat. § 388.01 (Supp. 1993). 
Notwithstanding the meteoric rise of public prosecutions in the United States, American citizens continued to privately prosecute criminal cases in many locales during the nineteenth century. ${ }^{26}$ In Philadelphia, for example, all types of cases were privately prosecuted, with assault and battery prosecutions being the most common. ${ }^{27}$ However, domestic disputes short of assault also came before the court. Thus, "[p]arents of young women prosecuted men for seduction; husbands prosecuted their wives' paramours for adultery; wives prosecuted their husbands for desertion."28 Although many state courts continued to sanction

26. See Sternberg, supra note 11 (detailing private prosecutions in Philadelphia); see also id. at 1-2 ("Private prosecution-one citizen taking another to court without the intervention of the police-was the basis of law enforcement in Philadelphia and an anchor of its legal culture, and this had been so since colonial times."); id. at 25 ("Early in the century, private cases were overwhelmingly dominant, but as the decades passed state prosecution became ever more prominent."). Notably, Allen Steinberg defines "private prosecution" as "the system by which private citizens brought criminal cases to the attention of court officials, initiated the process of prosecution, and retained considerable control over the ultimate disposition of cases-especially when compared with the two main executive authorities of criminal justice, the police and the public prosecutor." Id. at 5.

27. Steinberg, supra note 11 , at 44,50 . Under Philadelphia's system of private prosecution, many defendants sought to control the criminal process by becoming prosecutors themselves and initiating "cross-bills." Id. at 46 . According to one account:

Lewis Conrad's squirrel was attacked by Benjamin Morris's dog. Conrad kicked the dog, Morris kicked Conrad, and "a regular scraping took place." Morris accused Conrad before Alderman Binns, and Conrad brought Morris before Alderman Mitchell. "The dog and squirrel came off without harm, and have thus far avoided lawsuits," added the reporter. Id. at 46.

Occasionally such "cross-prosecutions" resulted in dual convictions. Id. at 67.

28. STEINBERG, supra note 11 , at 48 . Some private prosecutions in Philadelphia bordered on the bizarre. For example, "Henry Blake's wife prosecuted him for refusing to come to bed and making too much noise, preventing her from sleeping. $\mathrm{He}$ was bound over to come to bed when called." Id.; see also id. at 57 (defining "bound over" as "bound over for trial"). Likewise, a Southwark man "charged a fortune teller with conspiracy for beguiling his wife into believing that for a fee information could be provided about his infidelities." Id. (footnote omitted). Thus, private prosecutions "gave citizens the power, in practice, to define crime. Because the minor judiciary let them do so, almost anything that annoyed or irritated a person could be treated as a crime, for whatever motives a prosecutor might have." Id. at 77.

According to an 1863 article published by the Philadelphia Society for Alleviating the Miseries of Public Prisons, honest private prosecutors were rare: "Most of the complaints that come before our aldermen are brought by those who seek to gratify personal animosity and a sudden desire of vengeance rather than any wish to punish the wrong-doer for the sake of right." Id. at 199. To discourage abuses of the 
the practice of private prosecutions without significant scrutiny during the nineteenth century, ${ }^{29}$ a few state courts outlawed the practice. For instance, in 1849, the Massachusetts Supreme Court suggested in dicta that a privately retained prosecutor would void a criminal conviction. ${ }^{30}$ Likewise, Michigan prohibited the employment of private prosecutors in $1875 .^{31}$

In Wisconsin, the propriety of private prosecutors was left unquestioned until 1888 when the Wisconsin Supreme Court handed down its decision in Biemel v. State. ${ }^{32}$ In Biemel, the Wisconsin Supreme Court declared that "public policy, and the fair, just, and impartial administration of the criminal law of this state, make it the duty of the courts to

private prosecution system, Philadelphia did-for approximately twenty years-tax court costs against unsuccessful private prosecutors:

Between 1854 and 1874, the major weapon used by grand jurors to discourage petty prosecutions was still the power to place the court costs in ignored cases on the prosecutors. Judges told grand jurors that "by far the largest number of cases which will be submitted to you belong to a class originating in private spite. With those public justice has no concern. Criminal courts were not created to foment or to pander to either malice or extortion. We do not sit for the collection of bad debts or the accumulation of costs. All cases which fall within this category should be promptly ignored and the prosecutors ordered to pay the costs." Such an approach would "teach a few prosecutors not to repeat a costly experiment."

Id. at 183.

29. See People v. Powell, 25 P. 481 (Cal. 1891); State v. Rue, 75 N.W. 235 (Minn. 1893); Gardner v. State, 26 A. 30 (N.J. 1892); State v. Kent, 62 N.W. 631 (N.D. 1895); People v. Tidwell, 12 P. 61 (Utah 1886), reh'g denied, 12 P. 638 (Utah 1887); Jackson v. Commonwealth, 30 S.E.2d 452 (Va. 1898).

30. See Commonwealth v. Williams, 56 Mass. (2 Cush.) 582 (1849) (although a private attorney was permitted to assist the prosecutor at trial, there was no evidence that the private attorney received any pecuniary compensation for his services). The use of a private prosecutor was formally prohibited in Massachusetts in 1855. Commonwealth v. Gibbs, 70 Mass. (4 Gray) 146 (1855). But cf. Commonwealth v. Herman, 149 N.E. 198 (Mass. 1925) (allowing a privately retained attorney to sit with the prosecutor at counsel's table and consult with him).

31. See Meister v. People, 31 Mich. 99 (1875). Although the Michigan Supreme Court flirted with a retreat from its prohibition in a 1889 case, the ban on private prosecutors was reaffirmed only a year later. Compare People v. Schick, 42 N.W. 1008 (Mich. 1889) (although the record failed to establish that an assistant prosecutor had been retained by private parties, the court stated that even if such facts were established, the questioning of one witness and the argument of one motion would not require reversal) with People v. Hillhouse, 45 N.W. 484, 485-86 (Mich. 1890) (regardless of a private prosecutor's fairness toward a criminal defendant, the private prosecutor's participation constituted error).

32. 37 N.W. 244, 245-48 (Wis. 1888). 
exclude the paid attorneys of private persons from appearing as prosecutors." ${ }^{33}$ According to the Wisconsin Supreme Court:

[A]n attorney employed and paid by private parties should not be permitted either by the courts or by the prosecuting attorney to assist in the trial of such criminal cases .... "The prosecuting officer represents the public interests, which can never be promoted by the conviction of the innocent. His object, like that of the court, should be simply justice; and he has no right to sacrifice this to the pride of professional success." ... [The prosecutor has a duty to present evidence favorable to the defendant]. This method of presenting a case is not that favored or pursued in civil cases, where the paid attorneys of the respective parties conduct them. And criminal cases are not likely to be so presented if the prosecution is permitted to be conducted by the paid attorneys of parties who from passion, prejudice, or even an honest belief in the guilt [sic] of the accused, are desirous of procuring his conviction. ${ }^{34}$

Although a subsequent Wisconsin decision allowed a privately retained attorney to perform minor pretrial tasks, ${ }^{35}$ the Wisconsin courts have reaffirmed repeatedly the ban on the use of private prosecutors. ${ }^{36}$

33. Id. at 245 .

34. Id. at 245-48. In State v. Peterson, 218 N.W. 367 (Wis. 1928), a case decided forty years after Biemel, the Wisconsin Supreme Court reiterated its disdain for private prosecutors. According to the Peterson court:

In an early day in England private parties prosecuted criminal wrongs which they suffered. They obtained an indictment from a grand jury, and it became the duty and the privilege of the person injured to provide a prosecutor at his own expense to prosecute the indicted person. Our scheme of government has changed all this. It is now deemed the better public policy to provide for the public prosecution of public wrongs without any interference on the part of private parties, although they may have been injured in a private capacity different from the general public injury that accrues to society when a crime is committed. So under our system we have private prosecution for private wrongs and public prosecution for public wrongs.

Id. at 369 .

35. Scheldberger v. State, 235 N.W. 419 (Wis. 1931) (a private attorney was permitted to take witnesses' statements and do investigatory work).

36. See State v. Scherr, 101 N.W.2d 77 (Wis. 1960); State v. Peterson, 218 N.W. 367 (Wis. 1928); Rock v. Ekern, 156 N.W. 197 (Wis. 1916). 
Currently, a split of authority exists regarding whether private prosecutors are constitutionally permissible. While some jurisdictions prohibit the practice in its entirety, ${ }^{37}$ other jurisdictions allow the use of such prosecutors under the condition that the district attorney retain appropriate control over the prosecution. ${ }^{38}$ Only a few modern-day court decisions allow private prosecutors to retain unbridled discretion over a criminal prosecution. ${ }^{39}$ In some jurisdictions, the trial court has the discretion to determine whether a private attorney may assist a district attorney in the prosecution of a case..$^{40}$

\section{YOUNG V. UNITED STATES EX REL. VUITTON ET FILS S.A.}

In Young v. United States ex rel. Vuitton et Fils S.A., ${ }^{41}$ Louis Vuitton, S.A., a French leather goods manufacturer, brought suit in 1978 against several defendants alleging that Vuitton's trademark was being infringed by the manufac-

37. See infra notes $118-28$ and accompanying text.

38. See infra note $\mathbf{7 2}$ and accompanying text; Donald J. Hall, The Role of the Victim in the Prosecution and Disposition of a Criminal Case, 28 VAND. L. REv. 931, 976 (1975). The practice of requiring public prosecutors to control a criminal prosecution is at odds with some local nineteenth century practices, such as those of Philadelphia:

The discretion of the private parties in criminal cases was not checked by the public prosecutor. Instead, the public prosecutor in most cases adopted a stance of passive neutrality. He was essentially a clerk, organizing the court calendar and presenting cases to grand and petit juries. Most of the time, he was either superseded by a private attorney or simply let the private prosecutor and his witnesses take the stand and state their case. STEINBERG, supra note 11 , at 82.

39. See infra note 71 and accompanying text. In a few states, adultery statutes only permit the injured spouse to initiate a criminal prosecution. See, e.g., ArIz. Rev. Stat. Ann. § 13-1408(B) (1989); Мich. Comp. Laws § 750.31 (1990); Minn. STAT. $\$ 609.36(2)$ (1987); N.D. CENT. CODE $\$ 12.1-20-09(2)$ (1985); see also Lee v. State, 231 P. 324, 325 (Okla. Crim. App. 1924) (adultery is a "private wrong" that must be initiated by the injured person); State v. La Bounty, 116 P. 1073 (Wash. 1911) (the crime of adultery can only be prosecuted by a spouse).

40. People v. Powell, 25 P. 481, 486 (Cal. 1891); State v. Best, 186 S.E.2d 1 (N.C. 1972); State v. Woodruff, 392 S.E.2d 434, 436 (N.C. App. 1990), aff'd, 399 S.E.2d 114 (N.C. 1991) (per curiam). In such jurisdictions, it is often held that the trial judge's discretion in such matters will only be interfered with upon a showing of abuse of discretion. State v. Boykin, 259 S.E.2d 883 (N.C. 1979); Woodruff, 392 S.E.2d at 436 .

41. 481 U.S. 787 (1987). 
ture, sale, and distribution of imitation Vuitton goods. Three years later Vuitton's trademark was upheld by the Ninth Circuit, and Vuitton and the defendants then entered into a settlement agreement in 1982. Under the agreement, the defendants paid Vuitton $\$ 100,000$ in damages, and they consented to the entry of a permanent injunction prohibiting them from engaging in any economic activity related to Vuitton's registered trademark. ${ }^{42}$

In early 1983, however, a Florida investigation firm employed by Vuitton discovered possible violations of the permanent injunction in an undercover "sting" operation. Subsequently, Vuitton's attorney, J. Joseph Bainton, requested that the district court appoint him and his colleague, Robert Devlin, as special counsel to prosecute a criminal contempt action for violation of the permanent injunction. The district court granted Bainton's request, with the court finding probable cause to believe that the defendants in the earlier action were engaged in conduct violating the court's injunctive order. ${ }^{43}$ Although Bainton informed the United States Attorney's Office of his appointment and impending investigation, the head of that office merely wished Bainton good luck. ${ }^{44}$ Ultimately, despite the defendants' objections to the appointment of Bainton and Devlin as special prosecutors, the five defendants were convicted of criminal contempt for violating the injunction prohibiting the infringement of Vuitton's trademark. The defendants received sentences ranging from six months to five years. ${ }^{45}$

Before the United States Court of Appeals for the Second Circuit, the defendants urged that the appointment of Bainton and Devlin violated their right to be prosecuted by an impartial prosecutor. Citing its previous decision in

42. Young, 481 U.S. at 790-92. The permanent injunction prohibited the defendants from, among other things, "manufacturing, producing, distributing, circulating, selling, offering for sale, advertising, promoting or displaying any product bearing any simulation, reproduction, counterfeit, copy, or colorable imitation" of Vuitton's registered trademark. Id.

43. Id. at 792-93.

44. Id. at 793 .

45. Id. at 790-91 n.1, 793. 
Musidor, B.V. v. Great American Screen, ${ }^{46}$ however, the Second Circuit rejected the defendants' arguments. ${ }^{47}$ In particular, the Second Circuit held that the supervision of contempt prosecutions by a judge is adequate protection against the "danger that the special prosecutor will use the threat of prosecution as a bargaining chip in civil negotiations." 48 Thus, the Second Circuit affirmed the defendants' contempt convictions.

On appeal to the Supreme Court, the defendants first contended that the district court lacked the authority to appoint any private attorney to prosecute the contempt action against them. However, in rejecting the argument that only the U.S. Attorney's Office could have permissibly brought a contempt prosecution, a majority of the Supreme Court stated as follows: "[I]t is long settled that courts possess inherent authority to initiate contempt proceedings for disobedience to their orders, authority which necessarily encompasses the ability to appoint a private attorney to prosecute the contempt." 49 According to Justice Brennan's majority opinion:

Courts cannot be at the mercy of another Branch in deciding whether such proceedings should be initiated. The ability to appoint a private attorney to prosecute a contempt action satisfies the need for an independent means of self-protection, without which courts would be "mere boards of arbitration whose judgments and decrees would be only advisory." 50

46. 658 F.2d 60 (2d Cir. 1981), cert. denied, 455 U.S. 944 (1982). In Musidor, the Second Circuit held that neither due process nor Rule 42 of the Federal Rules of Criminal Procedure requires a court to select counsel from the staff of the United States Attorney's Office to prosecute a criminal contempt. Id. at 64.

47. See United States ex rel. Vuitton et Fils S.A. v. Klayminc, 780 F.2d 179 (2d Cir. 1985).

48. Id. at 184 .

49. Young, 481 U.S. at 794.

50. Id. at 797 (citing Gompers v. Bucks Stove \& Range Co., 221 U.S. 418, 450

(1911)). According to another passage of Justice Brennan's majority opinion:

While contempt proceedings are sufficiently criminal in nature to warrant the imposition of many procedural protections, their fundamental purpose is to preserve respect for the judicial system itself. As a result, courts have long had, and must continue to have, the authority to appoint private attorneys to initiate such proceedings when the need arises.

Young, 481 U.S. at 801-02. 
While recognizing that courts have the authority to appoint private attorneys to prosecute contempt violations, the Supreme Court specifically held that the exercise of that authority must be restrained by the principle that "only ' $\mathrm{t}$ ] he least possible power adequate to the end proposed' should be used in contempt cases." 51 In so stating, the Court held, in the exercise of its supervisory power, ${ }^{52}$ that the district court erred in appointing counsel for an interested party in connection with the contempt prosecution. According to the Court: "Regardless of whether the appointment of private counsel in this case resulted in any

51. Young, 481 U.S. at 802 (quoting United States v. Wilson, 421 U.S. 309, 319 (1975) and Anderson v. Dunn, 6 Wheat. 204, 231 (1821)). "This principle of restraint in contempt counsels caution in the exercise of the power to appoint a private prosecutor." Young, 481 U.S. at 802.

52. Several United States Supreme Court cases have delineated the scope of a court's "supervisory powers." For instance, in United States v. Hasting, the Court held that a federal court "may, within limits, formulate procedural rules not specifically required by the Constitution or the Congress." 461 U.S. 499, 505 (1983). But cf. Thomas v. Arn, 474 U.S. 140, 148 (1985) ("Even a sensible and efficient use of the supervisory power ... is invalid if it conflicts with constitutional or statutory provisions."). In so holding, the Hasting Court ruled that a court could not, by an assertion of its supervisory power, avoid the rule that a prosecutorial comment on the failure of an accused to testify is not per se error requiring automatic reversal of a conviction if the whole record indicates that the error was harmless beyond a reasonable doubt. In reaching this conclusion, the Supreme Court outlined the three purposes underlying the use of a court's supervisory powers: (1) "to implement a remedy for violation of recognized rights," (2) "to preserve judicial integrity by ensuring that a conviction rests on appropriate considerations validly before the jury," and (3) "as a remedy designed to deter illegal conduct." Id. at 505.

In a subsequent case, Bank of Nova Scotia v. United States, the Supreme Court also held that a court's supervisory power may not be invoked "to circumvent the harmless error inquiry prescribed by Federal Rule of Criminal Procedure 52(a)." 487 U.S. 250, 254 (1988) (citing Fed. R. CRIM. P. 52(a)). Justice Kennedy wrote the following:

Rule 52 is, in every pertinent respect, as binding as any statute duly enacted

by Congress, and federal courts have no more discretion to disregard the Rule's mandate than they do to disregard constitutional or statutory provisions. The balance struck by the Rule between societal costs and the rights of the accused may not casually be overlooked "because a court has elected to analyze the question under the supervisory power."

Bank of Nova Scotia, 487 U.S. at 255 (quoting United States v. Payner, 447 U.S. 727 , $736(1980))$.

In Bank of Nova Scotia, for an error not to be harmless, the Court held that the prosecutorial misconduct involved in that case must have "substantially influence[d]" the grand jury's decision to indict, thereby creating a "grave doubt" that the indictment was free from substantial influence. Bank of Nova Scotia, 487 U.S. at 256. 
prosecutorial impropriety (an issue on which we express no opinion), that appointment illustrates the potential for private interest to influence the discharge of public duty." 53 Citing numerous statutory and ethical duties related to conflicts of interest, the Young Court emphasized that "representation of other clients may compromise the prosecutor's pursuit of the Government's interest" because a prosecutor owes an ethical duty to those other clients. ${ }^{54}$ The Court stated as follows: "[I]t is the highest claim on the most noble advocate which causes the problem-fidelity, unquestioned, continuing fidelity to the client." "55

Having found that the trial court erred in appointing counsel for an interested party, the Young Court was then compelled to address whether the government should have the opportunity to demonstrate that it was "harmless error" for the court to appoint such counsel. ${ }^{56}$ Writing for four members of the Court with respect to this issue, Justice Brennan's opinion noted that "some errors 'are so funda-

53. Young, 481 U.S. at 806; id. at 807 (footnote omitted) ("[T]he appointment of counsel for an interested party to bring the contempt prosecution in this case at a minimum created opportunities for conflicts to arise, and created at least the appearance of impropriety."). According to the Court: "The prosecutor is appointed solely to pursue the public interest in vindication of the court's authority. A private attorney appointed to prosecute a criminal contempt therefore certainly should be as disinterested as a public prosecutor who undertakes such a prosecution." Id. at 805 (footnote omitted).

54. Id. at 804-05. That a lawyer cannot serve "two masters" is a recurring theme in Supreme Court opinions. E.g., United States v. Mississippi Valley Generating Co., 364 U.S. 520, 549 (1961) (statute prohibiting financial conflict-of-interest "has its foundation in the Biblical admonition that no man may serve two masters"); Glasser v. United States, 315 U.S. 60, 75 (1942) (representation of multiple codefendants created impermissible "struggle to serve two masters").

55. Young, 481 U.S. at 805 (quoting Brotherhood of Locomotive Firemen \& Enginemen v. United States, 411 F.2d 312, 319 (5th Cir. 1969)). In a footnote, Justice Brennan asserted that the potential for misconduct that arises through the appointment of an interested prosecutor is not outweighed by the fact that an attorney for the beneficiary of the court order may often be the most familiar with the underlying facts of the dispute. In so stating, Justice Brennan suggested in dicta that " $[t]$ hat familiarity may be put to use in assisting a disinterested prosecutor in pursuing the contempt action, but cannot justify permitting counsel for the private party to be in control of the prosecution." Young, 481 U.S. at 807 n.17.

56. The harmless error rule provides that "[a]ny error, defect, irregularity or variance which does not affect substantial rights shall be disregarded." FED. R. CRIM. P. 52(a). A constitutional error at trial requires the reversal of a conviction unless the government can establish that the error was harmless beyond a reasonable doubt. Chapman v. California, 386 U.S. 18 (1967). 
mental and pervasive that they require reversal without regard to the facts or circumstances of the particular case." "57 Reiterating the general rule that an error is fundamental if it undermines confidence in the integrity of the criminal proceeding, ${ }^{58}$ Justice Brennan concluded that "[t]he appointment of an interested prosecutor raises such doubts." 59 According to his opinion:

Prosecution by someone with conflicting loyalties "calls into question the objectivity of those charged with bringing a defendant to judgment." It is a fundamental premise of our society that the state wield its formidable criminal enforcement powers in a rigorously disinterested fashion, for liberty itself may be at stake in such matters. ${ }^{60}$

57. Young, 481 U.S. at 810-11 (quoting Delaware v. Van Arsdall, 475 U.S. 673, 681 (1986)). Only four members of the Supreme Court joined Part III B of the Young opinion, which holds, among other things:

[W]e establish a categorical rule against the appointment of an interested prosecutor, adherence to which requires no subtle calculations of judgment. Given the fundamental and pervasive effects of such an appointment, we therefore hold that harmless-error analysis is inappropriate in reviewing the appointment of an interested prosecutor in a case such as [Young].

Id. at 814 .

Notably, in New Jersey v. Imperiale, the State of New Jersey argued that criminal defendants in private prosecutor cases only suffer due process violations if their actual trial was fundamentally unfair. 773 F. Supp. 747 (D. N.J. 1991). The court in Imperiale noted: "This is the 'harmless error' approach, which stands bruised but intact given that Part III B of the [Young] opinion only carried four votes." Imperiale, 773 F. Supp. at 753 (footnote omitted). But see In re Davidson, 908 F.2d 1249, 1251 (5th Cir. 1990) (The Fifth Circuit has adopted as its own rule the position put forth by a plurality of the Young Court that "where as here, there is a Young violation, 'harmless error analysis is inappropriate.'") (citing Matter of Hipp, Inc., 895 F.2d 1503, 1509 (5th Cir. 1990)); see also Ganger v. Peyton, 379 F.2d 709, 714 (4th Cir. 1967) (harmless error analysis inappropriate where constitutional deficiency of conviction arises from conflicting roles of private attorney and prosecutor).

58. Young, 481 U.S. at 811 (citing Rose v. Clark, 478 U.S. 570, 577-78 (1986); Van Arsdall, 475 U.S. at 681-82; Vasquez v. Hillery, 474 U.S. 254, 263-64 (1986)).

59. Young, 481 U.S. at 811.

60. Id. at 811 (quoting Vasquez, 474 U.S. at 263). According to one scholar:

In its basic form, a conflict of interest arises when a person who has a duty to make decisions affecting others has some independent interest in the decision. We identify a lawyer's conflict by holding up relevant interests (of self or of others) against the lawyer's primary duties to her client. The duties required by conflict of interest rules are generally loyalty, confidentiality, and independent professional judgment exercised in the best interests of the client. 
Emphasizing that the public perception of the integrity of the criminal justice system is at stake, Justice Brennan stated that a concern for actual prejudice "misses the point." 61 " '[J]ustice must satisfy the appearance of justice,' and a prosecutor with conflicting loyalties presents the appearance of precisely the opposite." 62 Accordingly, "[s]ociety's interest in disinterested prosecution ... . would not be adequately protected by harmless-error analysis, for such analysis would not be sensitive to the fundamental nature of the error committed."63

In contrast to Justice Brennan's opinion, Justice Powell's opinion, joined by Chief Justice Rehnquist and Justice O'Connor, would have remanded the case to the Second Circuit to determine whether the error of appointing private counsel to prosecute the contempt proceeding was harmless error. Although Justice Powell's opinion asserted that, "as a general matter, courts should not appoint interested private lawyers to prosecute charges of criminal contempt," his opinion also took the position that Supreme Court precedents did not call for a "per se reversal."64 Indeed, noting that the Second Circuit had found "[no] rea-

Beth Nolan, Removing Conflicts from the Administration of Justice: Conflicts of Interest and Independent Counsels Under the Ethics in Government Act, 79 GEO. L.J. 1, 33-35 (1990) (footnotes omitted) [hereinafter Nolan].

61. Young, 481 U.S. at 813.

62. Id. at 812-13 (quoting Offutt, 348 U.S. at 14).

63. Young, 481 U.S. at 813 . Justice Brennan also concluded that the appointment of an interested prosecutor is "an error whose effects are pervasive." Id. According to his opinion:

Such an appointment calls into question, and therefore requires scrutiny of, the conduct of an entire prosecution, rather than simply a discrete prosecutorial decision. Determining the effect of this appointment thus would be extremely difficult. A prosecution contains a myriad of occasions for the exercise of discretion, each of which goes to shape the record in a case, but few of which are part of the record.

Id. at 813-14.

See also id, at 814 (citing Holloway v. Arkansas, 435 U.S. 475 (1978) (rejecting application of the harmless-error rule to a defense attorney's conflict in representing three codefendants)). In Holloway, the Supreme Court stated as follows: "[I]n a case of joint representation of conflicting interests the evil-it bears repeating-is in what the advocate finds himself compelled to refrain from doing, not only at trial but also as to possible pretrial negotiations and in the sentencing process." Holloway, 435 U.S. at $490-91$.

64. Young, 481 U.S. at 827 (Powell, J., concurring in part and dissenting in part). 
son to believe" that the private prosecutor acted unethically before the trial court, Justice Powell's opinion intimated that the Second Circuit's findings strongly suggested that the error of appointing private counsel to prosecute the contempt proceeding was harmless. Nevertheless, Justice Powell's opinion would have remanded the case to the Second Circuit for further findings regarding the "harmless error" issue. ${ }^{65}$ Neither Justice White's dissenting opinion ${ }^{66}$ nor Justice Scalia's concurring opinion, which argued for the reversal of the defendants' convictions on different grounds, ${ }^{67}$ reached the "harmless error" issue.

Although the Supreme Court's decision in Young was based upon its "supervisory powers,"68 Justice Blackmun, in a lone concurrence, would have held that "the practicefederal or state-of appointing an interested party's counsel to prosecute for criminal contempt is a violation of due process."69 According to Justice Blackmun's terse opinion, the concept of due process "requires a disinterested prosecutor with the unique responsibility to serve the public, rather than a private client, and to seek justice that is unfettered."70

65. Id.

66. Justice White's dissenting opinion merely stated that "there was no error, constitutional or otherwise, in the appointments made in this action and that petitioners were not denied due process of law by being tried and convicted of contempt." Young, 481 U.S. at 828 (White, J., dissenting).

67. Justice Scalia's concurring opinion argued that the appointment of private prosecutors was defective because prosecution of individuals who disregard court orders is not an exercise of "[t]he judicial power of the United States." Young, 481 U.S. at 816 (Scalia, J., concurring) (citing U.S. Const., ART. III, §§ 1, 2). According to Justice Scalia, " $[T]$ he federal courts have no power to prosecute condemners for disobedience of court judgments, and no derivative power to appoint an attorney to conduct contempt prosecutions." Id. at 826.

68. Justice Brennan's opinion in Young noted that the Court was relying on its supervisory authority "to avoid the necessity of reaching any constitutional issues." Young, 481 U.S. at $810 \mathrm{n} .21$.

69. Young, 481 U.S. at 815-16 (Blackmun, J., concurring).

70. Id. at 816 (citing Brotherhood of Locomotive Firemen \& Enginemen v. United States, 411 F.2d 312, 319 (5th Cir. 1969)). 


\section{EXISTING STATUTES AND CASE LAW}

\section{A. Jurisdictions Allowing Private Prosecutors}

Although a growing number of states prohibit the use of private prosecutors, many jurisdictions adhere to the rule allowing interested parties to retain such prosecutors. These latter jurisdictions differ as to the permissible scope private prosecutors can play in such actions. While three states, Alabama, Montana, and Ohio, allow private prosecutors to participate without the consent or supervision of the district attorney, ${ }^{71}$ the majority of jurisdictions allow participation only with the public prosecutor's consent and retention of control over the case. ${ }^{72}$ Another restriction placed upon the use of private prosecutors in most states is

71. See Alabama, Hall v. State, 411 So. 2d 831, 838 (Ala. Crim. App. 1981) ("[T] he appearance by a qualified attorney [for a private person] . . . does not require an appointment by any court, the District Attorney, or any of his assistants."); Montana, State v. Cockrell, 309 P.2d 316 (Mont. 1957) ("TThe court will indulge the presumption that the appointment was regularly made in the absence of a showing to the contrary."); Ohio, State v. Ray, 143 N.E.2d 484 (Ohio App. 1956) (private prosecutor was permissible despite fact that private counsel admitted that he was not affiliated with the city solicitor's office in any manner). However, in these states, the trial court has the discretion not to permit private prosecutors. See Hall, 411 So. $2 \mathrm{~d}$ at 838-39 (trial court can, for good cause, preclude the participation of a private prosecutor).

72. E.g., California, People v. Powell, 25 P. 481 (Cal. 1891); Colorado, Davis v. People, 238 P. 25 (Colo. 1925); Florida, Ates v. State, 194 So. 286 (Fla. 1940); Georgia, Allen v. State, 257 S.E.2d 5 (Ga. App. 1979); Brown v. State, 250 S.E.2d 438 (Ga. 1978); Illinois, People v. Farnsley, 293 N.E.2d 600, 605 (Ill. 1973); Hayner v. People, 72 N.E. 792 (IIl. 1904); Kansas, State v. Baker, 819 P.2d 1173 (Kan. 1991) State v. Berg, 694 P.2d 427, 431 (Kan. 1985); State v. Sandstrom, 595 P.2d 324 (Kan. 1979); Kentucky, Stumbo v. Seabold, 704 F.2d 910 (6th Cir. 1983) (applying Kentucky law); Commonwealth v. Hubbard, 777 S.W.2d 882 (Ky. 1989); Earl v. Commonwealth, 569 S.W.2d 686 (Ky. App. 1978); Louisiana, State v. Hopper, 203 So. 2d 222 (La. 1967); Maine, State v. Bartlett, 74 A. 18, 19 (Me. 1909); New Jersey, State v. Wouters, 177 A.2d 299 (N.J. Super. 1962); New Mexico, State v. Baca, 688 P.2d 34 (N.M. 1984); North Carolina, State v. Moose, 313 S.E.2d 507 (N.C. 1984); North Dakota, State v. Kent, 62 N.W. 631 (N.D. 1895); Oklahoma, Ryals v. State, 434 P.2d 488 (Okla. Crim. App. 1967); Pennsylvania, Commonwealth v. Musto, 35 A.2d 307 (Pa. 1944); South Carolina, State v. Addis, 186 S.E.2d 415 (S.C. 1972); South Dakota, State v. Basham, 170 N.W.2d 238 (S.D. 1969); Tennessee, State v. Bennett, 798 S.W.2d 783 (Tenn. App. 1990); Texas, Urdiales v. Canales, 475 F. Supp. 622 (S.D Tex. 1979); Ballard v. State, 519 S.W.2d 426 (Tex. Crim. App. 1975); Lopez v. State 437 S.W.2d 268 (Tex. Crim. App. 1969); Utah, People v. Tidwell, 12 P. 61 (Utah 1886); Vermont, 566 A.2d 970 (Vt. 1989); Virginia, Cantrell v. Commonwealth, 329 S.E.2d 22 (Va. 1985); Virgin Islands, Tonkin v. Michael, 349 F. Supp. 78 (V.I. 1972); West Virginia, State ex rel. Koppers Co. v. International Union of Oil, Chemical \& 


\section{the rule prohibiting their participation in related civil mat- ters. ${ }^{73}$ Several states have statutes that explicitly authorize the use of private prosecutors. ${ }^{74}$}

Atomic Workers, 298 S.E.2d 827 (W. Va. 1982); State v. Riser, 294 S.E.2d 461 (W. Va. 1982).

A handful of states allow only minimal participation by private prosecutors. E.g., State v. Newman, 568 S.W.2d 276, 282-83 (Mo. App. 1978) (prosecution witness has right to have private attorney appear, but witness' counsel had no right to otherwise participate in process of examination). Other jurisdictions have yet to articulate the permissible level of assistance that private prosecutors can provide. E.g., Smith v. State, 426 N.E.2d 364 (Ind. 1981) (private attorney introduced as "assistant" sat with public prosecutor at trial but did not participate); Sedelbauer v. State, 455 N.E.2d 1159, 1164 (Ind. App. 1983) (private prosecutor may assist in criminal trial); State v. von Bulow, 475 A.2d 995, 1003 (R.I. 1984) (stating merely that claim of private prosecution is "utterly without merit").

73. See Patricia Moran, Note, Private Prosecutors in Criminal Contempt Actions Under Rule 42(b) of the Federal Rules of Criminal Procedure, 54 FordHAM L. REv. 1141, 1154 n.54 (1986) (citing cases) [hereinafter Moran]. Indeed, an Alabama case decided in 1983 "is the only 20th century case holding unequivocally that a private prosecutor who also represents plaintiffs in a civil action arising out of the same proceeding presents no inherent due process or ethical problems." Id. at 1155 n.57 (citing Hopkins v. State, 429 So. 2d 1146, 1154 (Ala. Crim. App. 1983)). For a discussion of case law with respect to prosecutors' conflicts of interest, see Moran, supra, at 1155-62; Richard H. Underwood, Part-Time Prosecutors and Conflicts of Interest: A Survey and Some Proposals, 81 KY. L.J. 1 (1992-93) [hereinafter Underwood].

74. E.g., Ala. CODE $\S 28-4-314$ (1990) (private parties given the right to prosecute violations of laws prohibiting "the evils of intemperance"); KAN. STAT. ANN. $\$ 19-717$ (1988) (allowing the employment of a private prosecutor to assist the county attorney in any criminal matter); MiNN. STAT. \$211A.08 (1992) (allowing any person to employ an attorney to assist the county attorney in the investigation and prosecution of any violation related to a statute entitled "Fair Campaign Practices"); MINN. STAT. § 211B.16 (1992) (allowing any person to employ an attorney to assist the county attorney in the investigation and prosecution of any violation of a statute related to campaign financial reports); N.J. STAT. ANN. § 19:34-63 (West 1989) (allowing any citizen to employ an attorney to assist the prosecutor, and requiring that such attorney be recognized by the prosecutor and the court as associate counsel); NEw JERSEY LOCAL COURT RULE 7:4-4(b) (authorizing "any attorney" to prosecute an action); Or. REv. STAT. $\$ 135.165$ (1990) (allowing the employment of a private prosecutor to assist the county attorney in any criminal matter); OR. REv. STAT. $\$ 131.025$ (1990) (prosecuting party in criminal case is State of Oregon "[e]xcept for offenses based on municipal or county ordinances"); TENN. CODE ANN. \$ 8-7-401 (1993) ("A victim of crime or the family members of a victim of crime may employ private legal counsel to act as co-counsel with the district attorney general or his deputies in trying cases, with the extent of participation of such privately employed counsel being at the discretion of the district attorney general."); cf. W. VA. CODE 7-7-8 (1993) ("No provision of this section shall be construed to prohibit the employment of any person of a practicing attorney to assist in the prosecution of any person or corporation charged with a crime."). 
The application of such a statute was recently at issue in a Tennessee case, State $v$. Bennett ${ }^{75}$ where a murder victim's family employed two attorneys to serve as private prosecutors. Although the common law of Tennessee had recognized the right of a victim or the family of a deceased victim to employ private counsel to assist in a criminal prosecution, the Tennessee General Assembly enacted a statute in 1978 which expressly codified this common law right. According to the statute:

A victim of crime or the family members of a victim of crime may employ private counsel to act as co-counsel with the district attorney or his deputies in trying cases, with the extent of participation of such privately employed counsel being at the discretion of the district attorney general. The district attorney general or his deputies shall make the final and concluding argument. ${ }^{76}$

Despite the vigorous opposition of the defendant in Bennett to the participation of the private prosecutors at trial, the two private attorneys both actively participated in all phases of the prosecution against the defendant. On appeal, the constitutionality of the use of private prosecutors was upheld, with the court merely noting that the private prosecutors did not engage in prosecutorial misconduct or represent the family of the victim in a related civil suit. Noting that this prosecution was not a contempt prosecution arising out of a civil proceeding, the court rejected the defendant's due process and equal protection challenges to Tennessee's private prosecution statute. ${ }^{77}$ Although Bennett was decided in 1990, the Bennett court made no reference to the Supreme Court's 1987 decision in Young.

In assessing the constitutionality of private prosecutions, courts generally focus on the extent of trial participation by the private prosecutors. For example, in State $v$. Baker ${ }^{78}$ the Kansas Supreme Court addressed the issue of whether the defendant's right to a fair trial was violated

75. 798 S.W.2d 783 (Tenn. Crim. App. 1990).

76. Id. at 786 (citing TenN. CODE ANN. § 8-7-401 (1988)).

77. Id. at $785-86$.

78. 819 P.2d 1173 (Kan. 1991). 
where it was alleged that an assistant private prosecutor exceeded the scope of his involvement permitted by Kansas law. ${ }^{79}$ Noting that the attorney hired by the victims' families was an "assistant prosecutor," rather than a "special prosecutor," under Kansas law, ${ }^{80}$ the Baker court held that an assistant prosecutor "may take an active role in the proceedings, and need not confine himself to taking notes and advising the district attorney ...." 81 The privately retained attorney in Baker performed (1) the voir dire of the jury, (2) the direct and redirect examination of his client, (3) the direct and cross-examination of the psychiatric expert witnesses relative to the defendant's insanity defense, (4) the cross-examination of the defense witnesses, and (5) the sec-

79. Section 19-717 of the Kansas Statutes provides as follows:

That the prosecuting witness in any criminal action or proceeding may, at his own expense, employ an attorney or attorneys to assist the county attorney to perform his duties in any criminal action or proceeding under any of the laws of the state of Kansas, and such attorney or attorneys shall be recognized by the county attorney and court as associate counsel in such action or proceeding, and no prosecution shall be dismissed over the objection of such associate counsel until the reason of the county attorney for such dismissal, together with the objections thereto of such associate counsel, shall have been filed in writing, argued by counsel, and fully considered by the court.

Kan. Stat. AnN. § 19-717 (1988).

80. Section 19-717 of the Kansas Statutes governs the use of assistant prosecutors, while section 22-2202(17) of the Kansas Statutes governs the use of special prosecutors. Section 22-2202(17) of the Kansas Statutes defines a "[p]rosecuting attorney" as "any attorney who is authorized by law to appear for and on behalf of the state of Kansas in a criminal case, and includes the attorney general, an assistant attorney general, the county or district attorney, an assistant county or district attorney, and any special prosecutor whose appearance is approved by the court." In State v. Berg the Kansas Supreme Court discussed the difference between a special prosecutor and an assistant prosecutor.

[A]n attorney hired by the complaining witness to assist the prosecutor pursuant to $19-717$ is not a "special prosecutor" within the meaning of 22. 2202(19). Although we find no Kansas cases which define "special prosecutor," we are of the opinion that ... it refers to one who is temporarily appointed by the court to replace the absent county attorney pursuant to K.S.A. 19-711 or 19-715. The 19-717 attorney does not take over the role of the prosecutor. The controlling word in 19-717 is "assist." The attorney is to assist the prosecutor who will maintain ultimate control of the case. Berg, 694 P.2d 427, 431 (Kan. 1985).

81. Baker, 819 P.2d at 1184. In Berg, the Kansas Supreme Court held that an assistant prosecutor retained by the complaining witness did not have the right to take appeal from an order dismissing the criminal complaint. Berg, 694 P.2d at 42931; see also State ex rel. Rome v. Fountain, 678 P.2d 146, 153 (Kan. 1984) (a complaining witness has no right to challenge a decision by the prosecutor to dismiss). 
ond half of the State's closing argument. Rejecting the defendant's contention that the privately retained attorney was acting as the "lead" counsel for the State, ${ }^{82}$ the Baker court affirmed the defendant's conviction for, among other things, first degree murder and kidnapping. ${ }^{83}$

The high profile case of Person v. Miller ${ }^{84}$ provides a good illustration of how lower courts have analyzed the constitutionality of private prosecutors. In that case, Bobby Person, a black citizen of North Carolina, filed a class action suit in 1984 against the Carolina Knights of the Klu Klux Klan ("CKKKK"), and, among others, its leader, Glen Miller. The suit alleged that the defendants had engaged in a series of violent and intimidating acts against blacks throughout North Carolina, thereby depriving blacks of their rights under state and federal law. After the district court certified a class consisting of "all black citizens in the State of North Carolina," the parties to the lawsuit entered into a consent decree in 1985 which, inter alia, prohibited Miller and the CKKKK from "operat[ing] a paramilitary organization and do[ing] other acts" prohibited by North Carolina law. During the course of the litigation, Person was represented at all times by Morris Dees, a leading civil rights activist. ${ }^{85}$

In April 1986, Person's counsel, Dees, sought to cite Miller and the White Patriot Organization ("WPP"), the successor organization of the CKKKK, for criminal contempt of court. In this respect, Person's complaint alleged that Miller and the WPP had violated the court's order by operating a paramilitary organization and engaging in conduct in violation of North Carolina law. The court initially authorized Dees to prosecute the contempt action. ${ }^{86}$ Based upon the court's authorization, Dees actively prepared the

82. Baker, 819 P.2d at 1183.

83. Id. at 1176,1190 . Notably, the Kansas Supreme Court has recognized that "[a]n attorney who is hired by a complaining witness must act in the interest of his client which may not be in the interest of the general public." Berg, 694 P.2d at 432. But cf. Rome, 678 P.2d at 152 (a person representing the State must be a "lawtrained, independent public prosecutor rather than a vengeful prosecutor").

84. 854 F.2d 656 (4th Cir. 1988).

85. See Morris Dees, A Season for Justice (1991).

86. Person, 854 F.2d at 659. 
case until June 1986. He filed several amendments to the original complaint, moved the court to add various parties as defendants, and conducted discovery. However, in June 1986, the attorney for Miller moved to have Dees disqualified on the grounds that Dees' appointment violated the North Carolina Rules of Professional Conduct and Miller's due process right to be prosecuted by an impartial prosecutor. Ultimately, the district court ruled that the prosecution of the case must be under the "direct supervision and control" of the United States Attorney's Office, although Dees was authorized to "assist" the United States Attorney's Office "prior to and during the course of the trial." 87 At trial, Dees examined witnesses, participated in both opening and closing argument, as well as made and responded to objections and arguments. ${ }^{88}$

After Miller was convicted of criminal contempt, Miller appealed to the United States Court of Appeals for the Fourth Circuit, arguing that Dees' trial participation violated the rule established by the Supreme Court in Young. In particular, Miller contended that Dees functioned as "lead" or "primary" counsel, effectively controlling Miller's prosecution. In support of this contention, Miller asserted that

(1) Dees singly conducted the prosecution until the case was referred to the United State's Attorney's Office some two weeks prior to the original trial date;

(2) Dees took substantially more time in opening and closing arguments than did government trial counsel;

(3) Dees examined virtually all the significant witnesses, and

(4) Dees made and responded to most of the objections and arguments at trial. ${ }^{89}$

Accepting the accuracy of these assertions regarding the degree of Dees' participation, the Fourth Circuit held that the participation by Dees in the criminal contempt prosecution did not constitute reversible error. According to the opinion of Judge Phillips: "Dees' participation was

87. Id.

88. Id. at 663 .

89. Id. 
limited in its total compass to assisting government counsel in a subordinate role." 90 While acknowledging that the Supreme Court's decision in Young was relevant to the issue of Dees' trial participation, the Fourth Circuit distinguished the Young decision. According to the Fourth Circuit:

Young flatly proscribes turning the prosecution completely over to private counsel for interested parties, but it certainly did not proscribe all participation by such counsel. Indeed, and to the contrary, the Young Court was at pains to point out that private counsel's greater familiarity with the case might properly "be put to use in assisting a disinterested prosecutor in pursuing the contempt action." The limits of such allowable assistance were also suggested: assistance may not extend to the point that "counsel for the private party [is] ... in control of the prosecution."

Thus, the Person court read Young "at least implicitly to approve (or certainly not to forbid) the practice of allowing private counsel for interested parties to participate formally with government counsel in the prosecution of contempt citations" so long as three conditions were met. First, the participation of private counsel must have been approved by government counsel. Second, the private participation must consist solely of rendering assistance in a

90. Id.

91. Person, 854 F.2d at 663 (quoting Young, 481 U.S. at 806 n.17). According to the Person court:

The more appropriate analytic focus is on the evil at which the Young rule forbidding total abdication to private counsel for interested parties was aimed. That evil was the possibility that the criminal contempt sanction would be invoked and prosecuted by private counsel, operating in the adversarial mode, solely to secure advantage to his client and hence without regard for any interests of the defendant and the public in fairness of the criminal process. That evil is sufficiently guarded against-both in appearance and reality - by the presence of disinterested government counsel effectively in a position and manifestly prepared to exercise control over the critical prosecutorial decisions-most critically, whether to prosecute, what targets of prosecution to select, what investigative powers to utilize, what sanctions to seek, plea bargains to strike, or immunities to grant. It is control over these critical prosecutorial decisions which determine the fairness of particular prosecutions that is the important consideration; operational conduct of the trial is actually of subordinate concern, except as it may actually impact upon the more fundamental prosecutorial decisions.

Id. at 663-64 (citations omitted). 
subordinate role to government counsel. Finally, the participation must not rise "in practice to the level of effective control of the prosecution." 92

In several other post-Young cases, the families of crime victims have been allowed to retain private counsel to prosecute the accused. For example, in Commonwealth v. Hubbard ${ }^{93}$ the Kentucky Supreme Court allowed an attorney for the decedent's family to prosecute a defendant charged with reckless homicide. Likewise, in State $v$. Worley, ${ }^{94}$ the West Virginia Supreme Court affirmed a murder conviction where a county prosecutor withdrew an offer to accept the defendant's plea of guilty to the charge of first degree murder with a recommendation of mercy. This withdrawal came after a private prosecutor hired by the deceased's family relayed the family's wish that the case be vigorously prosecuted. ${ }^{95}$

Significantly, many pre-Young cases also approved of the use of private prosecutors retained by crime victims or their families. ${ }^{96}$ For instance, in Woods $v$. Linahan, ${ }^{97}$ the Fifth Circuit held that a defendant charged with murder and armed robbery was not denied due process by the participa-

92. Id. In this final respect, the Person court stated as follows: "We can conceive of situations in which without ever relinquishing effective control of the prosecution government counsel might for tactical reasons give over even more substantial portions of the actual conduct of trial to particularly skilled or knowledgeable private counsel." Id.

93. 777 S.W.2d 882 (Ky. 1989).

94. 369 S.E.2d 706, 718-19 (W. Va. 1988), cert. denied, 488 U.S. 895 (1988).

95. As one commentator has noted:

Because the allegiance owed by a private prosecutor to a possibly vengeful client must coexist with the impartiality demanded in the role of solicitor, a fair termination of any plea bargaining based on the equities of the situation is highly unlikely. The public solicitor who is in control of the plea bargain is less likely to be fair if he is assisted and counseled by a private advocate. If the private prosecutor is given control of the plea bargaining, the interest of his client might override those of the public in determining whether a plea to a lesser crime should be accepted.

John A.J. Ward, Note, Private Prosecution-The Entrenched Anomaly, 50 N.C. L. REV. 1171, 1175-76 (1972) (footnote omitted).

96. Park v. State, 170 S.E.2d 687 (Ga. 1969), vacated in part, 408 U.S. 935 (1972) (attorney allowed to assist prosecutor in murder case despite representation of widow in wrongful death action); State v. Addis, 186 S.E.2d 415 (S.C. 1972) (attorney representing family of deceased in wrongful death action allowed to participate in involuntary manslaughter prosecution).

97. 648 F.2d 973 (5th Cir. 1981). 
tion at trial of a private attorney retained and paid for by the family and friends of the victim. Although the private prosecutor's initial activities in Woods were said to "border on a constitutional violation,"98 the Fifth Circuit ultimately decided that the activities of a new district attorney, who took a more active role in the prosecution, ${ }^{99}$ "cured any defect that may have occurred in the pretrial stages" of the case. ${ }^{100}$ Although the use of a private prosecutor was approved in Woods, the Fifth Circuit was not without reservations:

While we find that no error is shown in this case, we note our concern about the practice of using a private attorney, paid by family and friends of the victim, to prosecute persons accused of murdering a person dear to the person paying the private prosecutor. Human experience indicates that an attorney who is paid by a group of people to provide a service has some loyalty to those persons paying his fee. This loyalty may serve to prejudice the well recognized rights of a defendant accused of committing a crime. While we do not intimate that a defendant will always be prejudiced by the participation of a private attorney in a criminal prosecution, the chances are greater in this situation than where the state's attorney, or an attorney appointed and paid by the state, prosecutes the case. ${ }^{101}$

Private prosecutors have been approved in pre-Young cases for all types of prosecutions, including murder prosecutions. ${ }^{102}$

98. The private prosecutor's initial activities in Woods included interviewing witnesses, filing motions, and developing trial strategy without the knowledge and consent of the district attorney.

99. The new district attorney made the opening statement, examined witnesses, and made the closing statement.

100. Woods, 648 F.2d at 977.

101. Id. In light of the Supreme Court's holding in Young that harmless error analysis is inappropriate, the Woods case is superseded by Young in that "prejudice" to the defendant is no longer the appropriate focus when considering whether a due process violation has occurred. Indeed, because the focus in Young was on the appearance of justice, the notion in Woods that prejudice is important is no longer relevant. See In re Davidson, 908 F.2d 1249, 1251 (5th Cir. 1990) (adopting as its own rule the position put forth by a plurality of the Young Court that "where, as here, there is a Young violation, "harmless error analysis is inappropriate"").

102. Powers v. Hauck, 399 F.2d 322 (5th Cir. 1968) (murder); Brooks v. State, 228 So. 2d 24 (Ala. Crim. App. 1969) (murder); Lopez v. State, 437 S.W.2d 268 (Tex. 
In some states, such as North Carolina, the use of private attorneys to assist in criminal prosecutions is said to have existed in North Carolina courts "from their incipiency."103 For example, in the pre-Young case of State $v$. Moose, ${ }^{104}$ the North Carolina Supreme Court stated that " $[t]$ he law in [North Carolina] with respect to private prosecutors is clear: absent some evidence that the private prosecutor has in fact ignored the interests of justice in seeking a conviction, his assistance of the public prosecutor is not a per se constitutional violation." 105 The court further stated the following:

[T]he defendant's concerns over the "fundamental fairness" of the use of private prosecutors in general are adequately addressed by existing safeguards. Private prosecutors, like all attorneys, are officers of the court, bound by the ethical responsibilities set forth in the Code of Professional Responsibility; guided by statutory rules and case law; and always controlled by the trial judge whose overriding concern is to insure orderly and evenhanded conduct in his courtroom. ${ }^{106}$

Nevertheless, when a trial court permits a private prosecutor to be employed in North Carolina, ${ }^{107}$ the district attor-

App. 1968) (murder); see also Comment, Private Prosecution: A Remedy for District Attorneys' Unwarranted Inaction, 65 Y ALE L.J. 209, 220 \& n.57 (1955) (citing cases where private prosecutors have been used to prosecute, among other crimes, murder, manslaughter, burglary, larceny, criminal libel, adultery, and rape).

103. State v. Best, 186 S.E.2d 1, 3 (N.C. 1972). In North Carolina, the use of private prosecutors has been upheld in numerous cases. State v. Westbrook, 181 S.E.2d 572 (N.C. 1971), vacated in part, 408 U.S. 939 (1972); State v. Carden, 183 S.E. 898 (N.C. 1936), cert. denied, 298 U.S. 682 (1936); see also State v. Branch, 220 S.E.2d 495, 517 (N.C. 1975), cert. denied, 433 U.S. 909 (1977) (the use of a private prosecutor did not create an atmosphere in which it was impossible for the defendant to receive a trial consistent with the requirements of due process). Nevertheless, the permissibility of private prosecutors in North Carolina rests within the discretion of the trial judge. Branch, 220 S.E.2d at 577; State v. Lippard, 25 S.E.2d 594, 599 (N.C. 1943), cert. denied, 320 U.S. 749 (1943).

104. 313 S.E.2d 507 (N.C. 1984).

105. Id. at 512 (citations omitted).

106. Id. at 513 .

107. In North Carolina, trial courts have the discretion to allow the use of private prosecutors. State v. Boykin, 259 S.E.2d 883, 891 (N.C. 1979), cert. denied, 446 U.S. 911 (1980). The trial court's discretion in this regard is only interfered with upon a showing of abuse of discretion. Id.; State v. Carden, 183 S.E. 898 (N.C. 1936), cert. denied, 298 U.S. 682 (1936). 
ney must remain in control of the prosecution. ${ }^{108}$ PostYoung cases in North Carolina have permitted the use of private prosecutors without citation to Young. ${ }^{109}$

In the state of West Virginia, the right to obtain a private prosecutor is likewise not absolute and has always been subject to judicial control and review. ${ }^{110}$ However, in order to overturn a conviction on appeal, a defendant must show that the private prosecutor's misconduct in some way prejudiced the defendant. ${ }^{111}$ A defendant is not subject to impermissible "prosecutorial overmatch" simply because a private attorney is retained by the victim's family to prosecute the case against the defendant. As the West Virginia Supreme Court stated in Acord v. Hedrick: "A mere imbalance between defense counsel and prosecution does not invalidate a criminal trial. Due process of law does not require that every criminal case be prosecuted by a Thomas Dewey, defended by a Clarence Darrow, and tried before a John Marshall."112

Pre-Young cases from other jurisdictions also have upheld the constitutionality of private prosecutors. For example, in Jones $v$. Richards, ${ }^{113}$ the defendant claimed that his constitutional right to an impartial prosecutor was violated by the simultaneous involvement of private attorneys (retained by the victim's family) in filing civil actions and as-

108. State v. Moose, 313 S.E.2d 507, 513 (N.C. 1984) ("The record before us discloses that the district attorney was at all times in control of the prosecution; that he adequately supervised the participation of the private prosecutor; and that the two attorneys worked as a team sharing the workload evenly."); State v. Page, 206 S.E.2d 771, 772 (N.C. Ct. App. 1974), cert. denied, 209 S.E.2d 287 (N.C. 1974).

109. State v. Camacho, 406 S.E.2d 868 (N.C. 1991); State v. Woodruff, 392 S.E.2d 434 (N.C. Ct. App. 1990), aff'd, 399 S.E.2d 114 (N.C. 1991) (per curiam).

110. Acord v. Hedrick, 342 S.E.2d 120, 126 (W. Va. 1986); State v. Atkins, 261 S.E.2d 55, 58 (W. Va. 1979), cert. denied, 445 U.S. 904 (1980).

111. Acord v. Hedrick, 342 S.E.2d 120, 126 (W. Va. 1986); State v. Riser, 294 S.E.2d 461, 466 (W. Va. 1982); see also State v. Atkins, 261 S.E.2d 55, 59 (W. Va. 1979) (it was not reversible error for private prosecutor not to disclose the amount of his fee).

112. Acord, 342 S.E.2d at 123 (citing Macklin Fleming, The Price of PerFECT Justice 5 (1974)); see also State v. Moose, 313 S.E.2d 507, 513 (N.C. 1984) ("Nor do we find persuasive the argument that assistance of a private prosecutor results in a 'mismatching' of legal talent and experience to a defendant's disadvantage. We know of no law that requires counsel to be equal to or better or greater in number than counsel for the opposition.").

113. 776 F.2d 1244 (4th Cir. 1985). 
sisting in North Carolina's prosecution of his criminal case. ${ }^{114}$ Although the Fourth Circuit, applying North Carolina law, noted that the private attorneys had a financial interest in the outcome of the civil actions, the Fourth Circuit held that no evidence demonstrated the private attorneys attempted to use their position as prosecuting attorneys "to exact a more generous settlement of the civil actions." 115 In another case, Sedelbauer $v$. State, ${ }^{116}$ an Indiana appellate court upheld the conviction of an adult bookstore worker for distributing an allegedly obscene film depicting homosexual acts, despite the trial court's decision to allow a member of an anti-obscenity group, Citizens for Decency through Law, to act as the public prosecutor's co-counsel. ${ }^{117}$

\section{B. Jurisdictions Prohibiting Private Prosecutors}

Several pre-Young cases either restricted or outlawed the use of private prosecutors on behalf of interested parties. ${ }^{118}$ For instance, in State $v$. Harrington, ${ }^{119}$ the defendant

114. But see Ganger v. Peyton, 379 F.2d 709, 713 (4th Cir. 1967) (where a prosecutor was representing the defendant's wife in a divorce action at the same time that he was prosecuting the defendant, the defendant's prosecutor "was not in a position to exercise fair-minded judgment with respect to (1) whether to decline to prosecute, (2) whether to reduce the charge to a lesser degree of assault, or (3) whether to recommend a suspended sentence or other clemency").

115. Jones, 776 F.2d at 1246; see also North Carolina State Bar Ethics Opinion 595 ("It is ethical for an attorney who has represented the private prosecution in a criminal action growing out of an automobile collision to later represent the same party in a civil action for damages growing out of the same collision.").

116. 455 N.E.2d 1159 (Ind. Ct. App. 1983).

117. Id. at 1164 .

118. Some state laws specifically prohibit the use of private prosecutors. For example, in Georgia, Superior Court Rule $\mathbf{4 2 . 1}$ provides that "[p]rivate special prosecutors retained by the family or relatives of one named as a victim in an indictment or accusation may not participate in the prosecution of a criminal case." But see Sustakovitch v. State, 290 S.E.2d 77 (Ga. 1982) (the victim's attorney, who was allowed to sit at counsel table, was not a special prosecutor); Rutledge v. State, 267 S.E.2d 199, 200 (Ga. 1980) (participation of special prosecutor hired by the victim's family did not violate the defendant's due process rights in a murder prosecution where the special prosecutor (1) was subject to the control and direction of the district attorney and (2) was not paid or reimbursed for his expenses by the district attorney's office); Rogers v. State, 348 S.E.2d 888 (Ga. Ct. App. 1986) (there was no violation of Rule 42.1 where a private attorney, representing the parents of a victim, assisted in arranging for the appearance of an expert witness in the defendant's prosecution where (1) the parents' attorney did not sit at counsel table, (2) the attorney took no part in the actual trial of the case, (3) the attorney did not assist in the 
was convicted of second degree murder after a private attorney, hired by the victim's father, assisted in the prosecution of the defendant's case. On appeal, however, the Supreme Court of Missouri held that "the practice of allowing private prosecutors, employed by private persons, to participate in the prosecution of criminal defendants, is fundamentally unfair." 120 Thus, the court held that the use of a private prosecutor should not be permitted on retrial of the case or "in any case tried after publication of this opinion in the Southwestern Reporter." ${ }^{21}$ Likewise, in Cantrell v. Virginia, ${ }^{122}$ the Virginia Supreme Court held that an attorney retained by an interested party could not prosecute the case. According to the court: "[A] private prosecutor having a civil interest in the case so infects the prosecution with the possibility that private vengeance has been substituted for impartial application of the criminal law, that no prejudice to the defendant need be shown."123

In the post-Young era, a handful of cases have held that the use of a private prosecutor violates a defendant's constitutional rights. For example, in People v. Calder-

preparation of the State's case and was not present when the expert witness was interviewed, and (4) the expert was paid by the State).

119. 534 S.W.2d 44 (Mo. 1976) (en banc).

120. Id. at 48. According to the Harrington court:

The modern day prosecutor wields the power of the State's investigatory force, decides whom to indict and prosecute, decides what evidence to submit to the court, negotiates the State's position in plea bargaining and recommends punishment to the court. The entry of a private prosecutor into a criminal prosecution exposes all of these areas to prejudicial influence. We consider such exposure intolerable.

Id. at 50 .

121. Id. at 48. A dissenting opinion in Harrington would have upheld the use of private prosecutors. According to that opinion: "The practice of employing private counsel is rarely used in this state. I see no necessity for this court, however, to decree that the practice is absolutely outlawed." Id. at 52 (Holman, J., dissenting).

In State ex rel. Wild $v$. Otis, the Minnesota Supreme Court held that, absent legislative authority, a system of private prosecution would not be permitted. 257 N.W.2d 361 (Minn. 1977), cert. denied, 434 U.S. 1003 (1978). Noting that it could find no such authority, the court stated, "[t]his [lack of authority] is not surprising because to permit such prosecutions would entail grave danger of vindictive use of the processes of the criminal law and could well lead to chaos in the administration of criminal justice." Id. at 365 .

122. 329 S.E.2d 22 (Va. 1985), cert. denied, 496 U.S. 911 (1990).

123. Id. at 26. 
one, ${ }^{124}$ a prosecution for criminal mischief in the fourth degree was commenced by the law firm of De Maio and Hughes on behalf of the owner of a condominium, Vincent Riso. The defendant was served with the summons and arraigned on the accusatory instrument which alleged that he caused damage to the carpet, walls, and doors of the condominium building in which Riso had an interest. Significantly, De Maio and Hughes, the law firm retained by Riso, was also representing Riso in a civil lawsuit against the defendant, who was a condominium unit owner. ${ }^{125}$

Under the facts of Calderone, a New York court granted the defendant's motion to disqualify the law firm of De Maio and Hughes. In so holding, the court concluded that private prosecutions by interested parties or their attorneys present inherent conflicts of interest which violate a defendant's due process rights. ${ }^{126}$ According to the court:

Compelling support for this conclusion is found in the opinions of Justices Brennan and Blackmun in Young $v$. United States. The Supreme Court of Wisconsin, one hundred years ago in Biemel v. State, 37 N.W. 244, 24445 (Wis. 1888), stated, "We think public policy, and the fair, just, and impartial administration of the criminal law of the state, make it the duty of the courts to exclude the paid attorneys of private persons from appearing as prosecutors." This court agrees and goes further, holding that due process requires that the individual who prosecutes a criminal case not have any personal or financial interest in the prosecution nor an attorney-client relationship with any of the parties. ${ }^{127}$

124. 573 N.Y.S.2d 1005 (N.Y. Crim. Ct. 1991).

125. Id. at 1005.

126. Id. at 1007 .

127. Id. at 1009 (citing Young v. United States ex rel. Vuitton et Fils S.A., 481 U.S. 787, 810, 814-15 (1987) (Justice Brennan's and Justice Blackmun's opinions)). Significantly, several other New York cases have discussed the propriety of private prosecutors. Compare People v. Garfield, 574 N.Y.S.2d 501, 502 (N.Y. Just. Ct. 1991) (" $[I] n$ the opinion of this Court . . . the failure to provide a professional evaluation of such cases by a neutral prosecutor may result in improper charges and convictions and denies a defendant the due process of law."); People v. Benoit, 575 N.Y.S.2d 750, 757 (N.Y. Crim. Ct. 1991) (private prosecution of tenant by landlord violates the tenant's due process and equal protection rights); People v. Zimmer, 434 N.Y.S.2d 206 (N.Y. 1980) (conviction of a corporation manager reversed where the district attorney had a financial interest in the corporation); People v. Franklin, 369 
In another New York case, People v. Benoit, ${ }^{128}$ a city statute providing for prosecutions by private citizens was held to violate not only the due process and equal protection clauses of the Fourteenth Amendment, but also the New York Constitution's due process clause. In Benoit, a landlord commenced a private prosecution against a tenant after the local district attorney declined to prosecute the tenant.

\section{PROSECUTORIAL ETHICS}

Prosecutors in the United States occupy a dual role in the criminal justice system. "They are the only governmental officers responsible for obtaining convictions of the guilty in litigated criminal cases; but they also bear alone the state's considerable responsibility to see that no innocent person is prosecuted, convicted, or punished."129 This dual role is in sharp contrast to the role of private counsel, whose primary obligation is to protect a client's interests. The Model Code of Professional Responsibility explicitly states that " $[t]$ he duty of a lawyer . . . is to represent his

N.Y.S.2d 531 (A.D.2d 1975) (permitting attorney representing one of complaining witnesses who was under indictment on unrelated charge to sit at counsel table and to object to questions put to witness on cross-examination was error that required new trial); People v. Vlasto, 355 N.Y.S.2d 983 (N.Y. Crim. Ct. 1974) (private prosecution of a Class A misdemeanor not authorized) with Read v. Sacco, 375 N.Y.S.2d 371 (N.Y.A.D. 2d Dept. 1975) (private prosecution of a Class A misdemeanor authorized); People v. Cuozzo, 412 N.Y.S.2d 748, 752 (City Ct. White Plains 1978) (court denied private attorney leave to prosecute a police officer involved in a traffic accident with his client-defendant because it was "virtually impossible to ask [the] defense attorney, or any defense attorney so situated, to act with objectivity and complete impartiality as a prosecutor in a criminal proceeding against a police officer who is responsible for the charge against his client"); People v. Vial, 502 N.Y.S.2d 930 (N.Y. Crim. Ct. 1986) (attorney for defendant prosecuted by district attorney permitted to act as prosecutor in cross-complaint against his accuser); Peter L. Davis, The Crime Victim's "Right" to a Criminal Prosecution: A Proposed Model Statute for the Governance of Private Criminal Prosecutions, 38 DEPAUL L. REv. 329 (1989) (detailing New York case law regarding the use of private prosecutors); see also Rochez v. Mittleton, 1993 WL 530947 (S.D.N.Y. Dec. 20, 1993) (dismissal of a 42 U.S.C. $\S 1983$ action against the City of New York, the Bronx District Attorney, and others alleging a deprivation of constitutional rights because of a municipal policy allowing private prosecutions to be commenced by any "complaining witness," including interested parties).

128. 575 N.Y.S.2d 750 (N.Y. Crim. Ct. 1991).

129. Charles W. Wolfram, Modern Legal Ethics, \$ 13.10.1, at 759 (1986) [hereinafter WOLFRAM]. 
client zealously within the bounds of the law."130 This situation has lead one scholar to remark that the prosecutor's role is "much nearer that of a judicial officer than that of partisan advocate."131

In Berger $v$. United States, ${ }^{132}$ the United States Supreme Court formally recognized the distinctive role that a prosecutor plays in American society. The Court declared the following:

The United States Attorney is the representative not of an ordinary party to a controversy, but of a sovereignty whose obligation to govern impartially is as compelling as its obligation to govern at all; and whose interest, therefore, in a criminal prosecution is not that it shall win a case, but that justice shall be done. As such, he is in a peculiar and very definite sense the servant of the law, the twofold aim of which is that guilt shall not escape nor innocence suffer. He may prosecute with earnestness and vigor-indeed, he should do so. But, while he may strike hard blows, he is not at liberty to strike foul ones. It is as much his duty to refrain from improper methods calculated to produce a wrongful conviction as it is to use every legitimate means to bring about a just one. ${ }^{133}$

130. Model Code of Professional Responsibiltty EC 7-1 (1984).

131. Wolfram, supra note $129, \S 13.10 .1$, at 759 (footnote omitted); see also Fred Zacharias, Structuring the Ethics of Prosecutorial Trial Practice: Can Prosecutors Do Justice?, 44 VAND. L. REv. 45 (1991) (outlining the ethical duty of prosecutors to "do justice"). Indeed, a "quasi-judicial" label has been attached to prosecutors. E.g., Imbler v. Pachtman, 424 U.S. 409, 423 n.20 (1976) (citations omitted) ("It is the fundamental comparability of their [discretionary] judgments to those of the judge that has resulted in both grand jurors and prosecutors being referred to as 'quasi-judicial' officers, and their immunities being termed 'quasi-judicial' as well."); id. at 438 (White, J., concurring) ("the prosecutor performs a 'quasi-judicial' function"); see also Ganger, 379 F.2d at 714; State v. Chambers, 524 P.2d 999, 100203 (1974), cert. denied, 524 P.2d 988 (N.M. 1974); McGinley v. Hynes, 432 N.Y.S.2d 689, 412 N.E.2d 376 (N.Y. 1980), cert. denied, 450 U.S. 918 (1981); State ex rel. Moran v. Ziegler, 244 S.E.2d 550, 552 (W. Va. 1978); State v. Boyd, 233 S.E.2d 710, 717 (W. Va. 1977); Sidman, supra note 11, at 792 \& n.193 (citing additional cases where prosecutors have been described as "quasi-judicial"); ABA Standards for Criminal Justice, Standard 3-1.1 cmt. (1979) ("[T]he prosecutor has sometimes been described as a 'minister of justice' or as occupying a quasi-judicial position.").

132. 295 U.S. 78 (1935).

133. Id. at 88; see also Polo Fashions, Inc. v. Stock Buyers Int'l, Inc., 760 F.2d 698,705 (6th Cir. 1985) ("It is too much to expect an attorney committed to his client and the client's cause to recognize the 'twofold aim' referred to in Berger 
This duty of fairness has been held to apply even where the prosecutor strongly believes that the accused is guilty. ${ }^{134}$

The unique role of the prosecutor was originally codified in Ethical Consideration 7-13 of Canon 7 of the American Bar Association's Model Code of Professional Responsibility. That Ethical Consideration reads as follows:

The responsibility of a public prosecutor differs from that of the usual advocate; his duty is to seek justice, not merely to convict. This special duty exists because: (1) the prosecutor represents the sovereign and therefore should use restraint in the discretionary exercise of governmental powers, such as in the selection of cases to prosecute; (2) during the trial the prosecutor is not only an advocate but he also may make decisions normally made by an individual client, and those affecting the public interest should be fair to all; and (3) in our system of criminal justice the accused is to be given the benefit of all reasonable doubts. With respect to evidence and witnesses, the prosecutor has responsibilities different from those of a lawyer in private practice: the prosecutor should make timely disclosure to the defense of available evidence, known to him, that tends to negate the guilt of the accused, mitigate the degree of the offense, or reduce the punishment. Further, a prosecutor should not intentionally avoid pursuit of evidence merely because he believes it will damage the prosecutor's case or aid the accused. ${ }^{135}$

The Model Rules of Professional Conduct, which have replaced the Model Code in most states, also make the prose-

when acting as prosecutor in proceedings which, if successful, can benefit immeasurably that client and his cause.").

134. State v. Sha, 193 N.W.2d 829 (Minn. 1972).

135. Model Code of Professional Responsibility EC 7-13 (1982); ABA Standards for Criminal Justice, Standard 3-1.1(c) (1979) ("The duty of the prosecutor is to seek justice, not merely to convict."); ABA Standards for Criminal Justice, Standard 3-1.1 cmt. (1979) ("[I]t is fundamental that the prosecutor's obligation is to protect the innocent as well as convict the guilty, to guard the rights of the accused as well as to enforce the rights of the public."); see Polo Fashions, 760 F.2d at 704-05; cf. Donnelly v. DeChristoforo, 416 U.S. 637, 648-49 (1974) ("The function of the prosecutor under the Federal Constitution is not to tack as many skins of victims as possible to the wall. His function is to vindicate the right of people as expressed in the laws and give those accused of crime a fair trial."). 
cutor's role explicit: "A prosecutor has the responsibility of a minister of justice and not simply that of an advocate. This responsibility carries with it specific obligations to see that the defendant is accorded procedural justice and that guilt is decided upon the basis of sufficient evidence."136 Thus, the Supreme Court has "long emphasized" that a prosecutor is held to "a higher standard of behavior" than defense counsel. ${ }^{137}$

As attorneys, all prosecutors are subject to the applicable ethical codes and laws in their respective jurisdictions. For example, under federal law, the Justice Department mandates that its attorneys follow the ABA's Model Code of Professional Responsibility, ${ }^{138}$ which contains numerous provisions relating to conflicts of interest. ${ }^{139}$ Furthermore, federal prosecutors are prohibited by statute from representing the government in any matter in which they, their family, or their business associates have any interest. ${ }^{140}$

136. Model Rules of Professional Conduct Rule $3.8 \mathrm{cmt}$. (1984).

137. United States v. Young, 470 U.S. 1, 25 (1985) (Brennan, J., concurring in part and dissenting in part).

138. 28 C.F.R. \$ 45.735-1(b) (1986).

139. See Model Code of Professional Responsibility DR 5-105 (1982) (lawyer should refuse to accept or continue employment if the interests of another client may impair the exercise of his or her independent judgment); EC 5-1 (professional judgment of lawyer should be exercised solely for the benefit of client, free of "compromising influences and loyalties"); EC 5-2 (lawyer should not accept proffered employment if reasonable probability that personal interests will "affect adversely the advice to be given or services to be rendered the prospective client"); EC 5-14 (independent professional judgment compromised when lawyer asked to represent two or more clients "who may have differing interests, whether such interests be conflicting, inconsistent, diverse, or otherwise discordant"); EC 5-15 (if possibility of conflict in representation of multiple clients, lawyer "should resolve all doubts against the propriety of the representation"); EC 9-6 (lawyer has duty to avoid "not only professional impropriety but also the appearance of impropriety"). For an article discussing prosecutorial conflict of interest issues, see Susan Brenner \& James Durham, Towards Resolving Prosecutor Conflicts of Interest, 6 GEO. J. LEGAL ETHICs 415 (1993).

140. 18 U.S.C. \& 208(a) (1988); see also United States v. Heldt, 668 F.2d 1238 (D.C. Cir. 1981) (per curiam) (prosecutor cannot participate in case in which he has a pecuniary interest in the outcome), cert. denied sub nom., Hubbard v. United States, 456 U.S. 926 (1982); Nolan, supra note 60, at 47-50 (detailing the conflict of interest provisions to which federal prosecutors are subject). Notably, the United States Attorney's Manual also cautions against activity that "creates or appears to create a conflict of interest." United States Attorney's Manual, Title 10-2.664 (1984); see also id. at $\$ 10-2.666$ (cautioning lawyers about membership in bar groups, public commissions, and private business organizations because of the po- 
State laws have similar ethics provisions for prosecutors, ${ }^{141}$ with all attorneys being subject to professional discipline, a court's contempt power, and a court's "supervisory authority." 142

Aside from these regulatory constraints, prosecutors have ethical duties to defendants during every stage of the criminal process. For example, a prosecutor has an obligation to deal fairly in presenting an ex parte case to the grand jury. Thus, in United States v. Hogan, ${ }^{143}$ an indictment was dismissed because a prosecutor's misconduct before the grand jury was fundamentally unfair. ${ }^{144}$ Likewise, prosecutors are obligated to protect an individual's pretrial rights ${ }^{145}$ and are obligated not to seek convictions in cases that are not supported by "probable cause."146

tential for an appearance of a conflict of interest); id. at $\S 10-2.660$ (incorporating the Department of Justice Standards of Conduct, 28 C.F.R. $\$ 45$ (1984), which contain broad restrictions regarding the permissible activities of employees in order to avoid any actual or apparent conflict of interest).

141. E.g., Minnesota Rules of Professional Conduct Rule 3.8 (1988); see also State v. Marshall, 586 A.2d 85 (N.J. 1991) (court can disqualify prosecutor for personal interest or financial stake in outcome of criminal prosecution). Significantly, many states have enacted laws which prohibit prosecutors from accepting fees from private parties and from participating in civil actions whose facts form the basis of a criminal case. Sidman, supra note 11, at $778 \&$ n.132 (citing statutes). For a recent annotation addressing the issue of when a prosecuting attorney must be disqualified based upon a relationship with the alleged victim or the victim's family, see Christopher Vaeth, Disqualification or Recusal of Prosecuting Attorney Because of Relationship With Alleged Victim or Victim's Family, 12 A.L.R. 5TH 909 (1993) (citing cases).

142. Wolfram, supra note $129, \S 13.10 .2$, at $760-61$ (citations omitted); see also State v. Wilson, 545 A.2d 1178, 1183 (Del. 1988) ("[a] court may, through its inherent authority to regulate the status of those who appear before it in a representative capacity, preclude the privatization of prosecutions initiated by a public prosecutor").

143. 712 F.2d 757 (2d Cir. 1983).

144. Id. at 759-62; see also United States v. Serubo, 604 F.2d 807 (3d Cir. 1979); United States v. Chanen, 549 F.2d 1306 (9th Cir. 1977), cert. denied, 434 U.S. 825 (1977).

145. Under the Model Rules of Professional Conduct, a prosecutor "shall . . make reasonable efforts to assure that the accused has been advised of the right to, and the procedure for obtaining, counsel and has been given reasonable opportunity to obtain counsel ..." Model Rules of Professional Conduct Rule 3.8(b) (1984). Likewise, a prosecutor cannot "seek to obtain from an unrepresented accused a waiver of important pretrial rights, such as the right to a preliminary hearing ...." Model Rules of Professional Conduct Rule 3.8(c) (1984).

146. Model Code of Professional Responsibility DR 7-103(A) (1982); Model Rules of Professional Conduct Rule 3.8(a) (1984); Calif. R. 7-102; 
At trial, the prosecutor is obligated not to present false evidence. As the Supreme Court has stated in numerous cases, the violation of this duty offends due process and requires the reversal of a defendant's conviction. ${ }^{147}$ Thus, as soon as the prosecutor is aware of false testimony, he or she has a duty to correct it, usually by disclosing the correct information to the defendant. ${ }^{148}$ Due process jurisprudence developed by the Supreme Court in Brady v. Maryland ${ }^{149}$ also requires prosecutors to produce to defendants exculpatory material and evidence useful to impeach government witnesses. ${ }^{150}$

Prosecution Function Standards \$ 3-3.9 (approved 1979); see also MinNESOTA Rules of Professional Conduct Rule 3.8(a) (1988); United States v. Lovasco, 431 U.S. 783 (1977) (it is "unprofessional conduct for a prosecutor to recommend an indictment on less than probable cause"); Commonwealth v. Hawkins, 469 A.2d 252, 255 (Pa. Super. 1983) (action should not go forward absent probable cause); In re Gonyo, 245 N.W.2d 893 (Wis. 1976) (prosecutor disciplined for breach of obligation to prosecute only on probable cause). Notably, some scholars have argued that prosecutors should be required to be personally convinced that the accused is guilty beyond a reasonable doubt before commencing a prosecution. M. Freedman, LaWyers' Ethics in an AdVersary System 85-88 (1975).

Significantly, the Supreme Court's decision in Yick Wo v. Hopkins, where the conviction of a Chinese person for operating a laundry without a license was reversed, also prohibits selective prosecution that is discriminatory in nature. 118 U.S. 356 (1886). In Yick Wo, the record demonstrated that almost all Chinese who applied for a license were refused, while nearly all non-Chinese applicants received licenses. Under these facts, the Yick Wo Court held that discriminatorily selective enforcement is a complete bar to prosecution; it was irrelevant that the accused was guilty of the underlying criminal offense.

147. Miller v. Pate, 386 U.S. 1 (1967); Alcorta v. Texas, 355 U.S. 28 (1957); Mooney v. Holohan, 294 U.S. 103 (1935); see also United States v. Kelly, 543 F. Supp. 1303, 1309-10 (D. Mass. 1982) (a prosecutor may not present evidence that "he actually knows, or should know, to be false").

148. United States v. Agurs, 427 U.S. 97, 103-04 (1976); Giglio v. United States, 405 U.S. 150 (1972); Napue v. Illinois, 360 U.S. 264 (1959); Mooney v. Holohan, 294 U.S. 103 (1935).

149. 373 U.S. 83 (1963). The Supreme Court in Brady held that "suppression by the prosecution of evidence favorable to an accused upon request violates due process where the evidence is material either to guilt or punishment." Id. at 87 .

150. Id. at 87; United States v. Bagley, 473 U.S 667, 676 (1985); Giglio v. United States, 405 U.S. 150, 154 (1972). In Bagley, the Supreme Court held that the prosecution must disclose evidence "if there is some reasonable probability that, had the evidence been disclosed to the defense, the result of the proceeding would have been different." A "reasonable probability" is one that is "sufficient to undermine confidence in the outcome." Bagley, 473 U.S. at 682. For a discussion of this issue, see Terrence Galligan, The Prosecutor's Duty to Disclose Exculpatory Evidence After United States v. Bagley, 1 Geo. J. L. EтHICs 213 (1987). 
In the United States, several court decisions have cited ethics provisions in rejecting the use of private prosecutors. ${ }^{151}$ For example, in Young, the United States Supreme Court relied upon ethics provisions which require that lawyers avoid conflicts of interest and avoid the mere appearance of impropriety. ${ }^{152}$ Although courts disagree about the effect of a prosecutor's breach of the ethical rules, ${ }^{153}$ the Supreme Court's language in Young strongly suggests that professional ethics are an important consideration in analyzing a criminal defendant's due process rights. ${ }^{154}$

151. E.g., Young, 481 U.S. at 803-06 \& nn.14-16; State v. Harrington, 534 S.W.2d 44, 50 (Mo. 1976); see also ABA Standards for Criminal Justice, Standard 3-2.1 (1979) (emphasis added) ("The prosecution function should be performed by a public prosecutor who is a lawyer subject to the standards of professional conduct and discipline.").

152. Young, 481 U.S. at $805 \& \mathrm{nn} .14-15$; accord ABA Standards for Criminal Justice, Standard 3-1.2 (1979) ("A prosecutor should avoid the appearance or reality of a conflict of interest with respect to official duties."); ABA Standards for Criminal Justice, Standard 3-1.2 cmt. (1979) ("It is of utmost importance that the prosecutor avoid participation in a case in circumstances where any implication of partiality may cast a shadow over the integrity of the office."); MODEL CODE OF PROFEsSIONAL RESPONSIBILITY Canon 9 (1983) ("A lawyer should avoid even the appearance of professional impropriety."). Although the Model Rules of Professional Conduct do not contain the "appearance of impropriety" language, largely because the drafters of the Model Rules felt the standard was too vague, the principle of Canon 9 is very much alive. First Am. Carriers, Inc. v. Kroger Co., 787 S.W.2d 669, 671-72 (Ark. 1990) ("The fact that Canon 9 is not in the Model Rules does not mean that lawyers no longer have to avoid the appearance of impropriety ... . [T]he principle [of Canon 9 still] applies because its meaning pervades the Rules and embodies their spirit."); see also Andrew Kaufman, Problems in Professional ReSPONSIBILITY 54 (2d ed. 1984) (The term "appearance of impropriety" "evoke[s] the potential erosion of confidence in the profession that may occur if its members are seen in situations that carry the potential for improper conduct even if in particular cases there is no actual misconduct.").

153. Compare Universal Athletic Sales Co. v. American Gym, Recreational \& Athletic Sales Equip. Corp., 546 F.2d 530, 539 (3d Cir. 1976), cert. denied, 430 U.S. 984 (1977) (holding that ethical rules regulate attorney conduct but do not "delineate the rules of evidence") with United States v. Hammad, 858 F.2d 834, 840 (2d Cir. 1988) (holding that suppression or exclusion of evidence may be a proper remedy for a prosecutor's ethical breach); United States v. Killian, 639 F.2d 206, 210 (5th Cir.), cert. denied, 451 U.S. 1021 (1981) (same); United States v. Springer, 460 F.2d 1344, 1353-54 (7th Cir. 1972) (same); United States v. Lopez, 765 F. Supp. 1433 (N.D. Cal. 1991) (same).

154. Accord Wheat v. United States, 486 U.S. 153, 160 (1988) ("Federal courts have an independent interest in ensuring that criminal trials are conducted within the ethical standards of the profession and that legal proceedings appear fair to all who observe them."). 


\section{THE UNCONSTITUTIONALITY OF PRIVATE PROSECUTORS}

\section{A. The Law of Due Process}

The due process clause of the Fifth Amendment prohibits the federal government from depriving an individual "of life, liberty, or property, without due process of law."15s The states are similarly restricted by the Fourteenth Amendment, which provides in part, "nor shall any State deprive any person of life, liberty, or property, without due process of law."156 Above all else, "[t]he fundamental requirement of due process is the opportunity to be heard at a meaningful time and in a meaningful manner." 157 Although it would be impossible for the Supreme Court to define what process is due in all circumstances, ${ }^{158}$ the Supreme Court, over time, has used several methods to determine whether a specific procedure is required in a given case.

According to two legal scholars, Martin Redish and Lawrence Marshall, the Supreme Court has used three approaches in the last two centuries to determine how much process is due. ${ }^{159}$ Initially, the Supreme Court looked to what procedures were required by the English common law. For example, in Murray's Lessee v. Hoboken Land \& Improvement Co. ${ }^{160}$ the Supreme Court analyzed the types of procedures that the framers of the Fifth Amendment

155. U.S. Const. amend. V.

156. U.S. CoNST. amend XIV, $\S 1$. It is firmly established that prosecutors' actions "may constitute state action within the purview of the Fourteenth Amendment." Mooney v. Holohan, 294 U.S. 103 (1935); see also Sidman, supra note 11, at 787-88 (same).

157. Mathews v. Eldridge, 424 U.S. 319, 333 (1976) (citation omitted). The Supreme Court "consistently has held that some form of hearing is required before an individual is finally deprived of a property interest." Id.; accord Wolff v. McDonnell, 418 U.S. 539, 557-58 (1974).

158. "[D]ue Process is flexible and calls for such procedural protections as the particular situation demands." Morrissey v. Brewer, 408 U.S. 471 (1972).

159. See generally Martin H. Redish \& Lawrence C. Marshall, Adjudicatory Independence and the Values of Procedural Due Process, 95 Y ALE L.J. 455, 468-72 (1986)[hereinafter Redish \& Marshall]; see also LAURENCE H. TRIBE, AMERICAN Constitutional Law $\S 10-13$, at 714-15 (1988) (outlining the Court's shifting methods of determining what process is due) [hereinafter TRIBE].

160. 59 U.S. (18 How.) 272 (1855). 
would have considered "the law of the land."161 However, this "frozen-in-history" approach did not last long. ${ }^{162}$ Thus, in Twining $v$. New Jersey, ${ }^{163}$ the Supreme Court stated that the meaning of the due process clause "should be gradually ascertained by the process of inclusion and exclusion in the course of decisions of cases as they arise." ${ }^{164}$ In essence, the Supreme Court abandoned the historical approach in favor of asking "whether a given procedure was essential to modern-as opposed to 17th century-notions of fairness."165

Having decided that history provides neither a floor nor a ceiling to modern due process, the Court began to struggle with the task of determining on a case-by-case basis whether a given procedure violated due process. For a long time, the Court seemed to deal in a rather intuitive way with the question of how much process was due .... During the Court's "intuitive" period, the Justices generally tended to treat due process as Justice Stewart treated obscenity-as recognizable, albeit undefinable. ${ }^{166}$

In Mathews v. Eldridge, ${ }^{167}$ the Supreme Court embarked on its third due process approach. This approach, which involves a "mechanical" balancing of interests, ${ }^{168}$ articulates three areas of critical importance for a court to consider in determining what process is due:

First, the private interest that will be affected by the official action; second, the risk of an erroneous deprivation of such interest through the procedures used, and the probable value, if any, of additional or substitute

161. Id. at 277.

162. Redish \& Marshall, supra note 159 , at 469.

163. 211 U.S. 78 (1908).

164. Id. at 100 (emphasis added).

165. Redish \& Marshall, supra note 159, at 468 (citing Twining, 211 U.S. at 101); see also Adamson v. California, 332 U.S. 46, 61 (1947) (Frankfurter, J., concurring) (asking whether procedures are necessary for the "protection of ultimate decency in a civilized society"); Snyder v. Massachusetts, 291 U.S. 97, 116 (1934) ("due process of law," according to Justice Cardozo, "requires that the proceedings shall be fair"). For a source containing essays regarding the "original intent" debate, see INTERpreting the Constitution: The Debate Over Original Intent (Jack Rakove ed. 1990).

166. Redish \& Marshall, supra note 159 , at 470 (footnote omitted).

167. 424 U.S. 319 (1976).

168. Redish \& Marshall, supra note 159 , at $470-71$. 
procedural safeguards; and finally, the Government's interest, including the function involved and the fiscal and administrative burdens that the additional or substitute procedural requirement would entail. ${ }^{169}$

Although due process rights are often invoked in cases involving actual bias on the part of an adjudicator, the due process guarantee also prohibits the mere appearance of impropriety on the part of a decision maker. Thus, in Offutt v. United States, ${ }^{170}$ the Supreme Court held that "justice must satisfy the appearance of justice." ${ }^{171}$ This language, which is found repeatedly in Supreme Court cases, ${ }^{172}$ is often used to protect due process rights. For example, in In re Murchison, ${ }^{173}$ the Supreme Court cited this language to prohibit a trial judge, who acted as a one-man grand jury, from finding two of the grand jury witnesses guilty of contempt in a subsequent proceeding. According to the Court:

A fair trial in a fair tribunal is a basic requirement of due process. Fairness of course requires an absence of actual bias in the trial of cases. But our system of law has always endeavored to prevent even the probability of unfairness .... [T] perform its high function in the best way, "justice must satisfy the appearance of justice." 174

Although this rule "'may sometimes bar trial judges who have no actual bias,' it is a necessary prophylactic rule to

169. Mathews, 424 U.S. at 335; see also Connecticut v. Doehr, 501 U.S. 1 (1991). Notably, "[t]he word 'fairness' did not appear in the balancing test; the Court apparently chose to focus upon considerations of economic efficiency instead. The notions of elemental fairness that had been so dispositive under the 'intuitive' approach were now abandoned in favor of the new-economic efficient-due process." Redish \& Marshall, supra note 159, at 472. Despite the lack of the word "fairness" in the balancing test, the Supreme Court recently reiterated that "[p]rocedural due process" remains "a guarantee of fair procedure." Zinermon v. Burch, 494 U.S. 113; 125 (1990) (emphasis added).

170. 348 U.S. 11 (1954).

171. Id. at 14.

172. E.g., Aetna Life Ins. Co. v. Lavoie, 475 U.S. 813, 822 (1986) (quoting In re Murchinson); Richmond Newspapers, Inc. v. Commonwealth of Virginia, 448 U.S. 555, 594 (1980) (Brennan, J., concurring) (quoting Offutt); Levine v. United States, 362 U.S. 610, 616 (1960) (quoting Offutt).

173. 349 U.S. 133 (1955).

174. Id. at 136 (quoting Offutt). 
preserve the defendant's fourteenth amendment rights because proof of actual bias may be too difficult." ${ }^{175}$

\section{B. An Unbiased Judicial System and the Appearance of Evenhanded Justice}

In numerous cases, the United States Supreme Court has ruled that the judicial process must be free of partisan influences. ${ }^{176}$ For instance, in Tumey $v$. Ohio, ${ }^{177}$ the Supreme Court ruled that a judge must be disqualified when there is a "direct, personal, substantial, pecuniary interest in the matter before the court."178 Furthermore, the Supreme Court has held that a judge is not allowed "to try

175. Jon Bancone, Note, Article III and Due Process Limitations on the FSLIC's Adjudicatory Role During Its Receiverships, 76 GEO. L.J. 1845, 1861 (1988) (quoting Taylor v. Hayes, 418 U.S. 488, 501 (1974)).

176. Cuyler v. Sullivan, 446 U.S. 335 (1980) (defense counsel cannot have an actual conflict of interest); Connally v. Georgia, 429 U.S. 245 (1977) (per curiam) (system invalidated in which justices of the peace were paid for issuance but not for nonissuance of search warrants); Taylor v. Hayes, 418 U.S. 488 (1974) (prohibiting the trial of a defendant before a judge who had previously held the defendant in contempt); Gibson v. Berryhill, 411 U.S. 564 (1973) (prohibiting an administrative board consisting of optometrists in private practice from hearing charges filed against optometrists competing with board members); Morrissey v. Brewer, 408 U.S. 471 (1972) (prohibiting parole officers from making parole revocation decisions); Tumey v. Ohio, 273 U.S. 510 (1927) (judges must be free from bias); $c f$. Marshall v. Jerrico, Inc., 446 U.S. 238 (1980) (articulating standard for administrative prosecutors).

177. 273 U.S. 510, 523 (1927).

178. As Justice Brennan has noted, due process may also require a judge's recusal when his or her participation may affect nonpecuniary interests. See Aetna Life Ins. Co. v. Lavoie, 475 U.S. 813, 829-30 (1986) (Brennan, J., concurring). Indeed, the mere participation of a judge in a decision may violate due process even if the judge's participation would not necessarily affect the outcome of the proceeding. See id. at 831 (Blackmun, J., concurring) (a judge's "mere participation in the shared enterprise of appellate decision making - whether or not he ultimately wrote, or even joined, the Alabama Supreme Court's opinion-posed an unacceptable danger of subtly distorting the decision making process"). According to another passage from Justice Brennan's opinion:

[W] hile the influence of any single participant in this process can never be measured with precision, experience teaches us that each member's involvement plays a part in shaping the court's ultimate disposition. The participation of a judge who has a substantial interest in the outcome of a case of which he knows at the time he participates necessarily imports a bias into the deliberative process. This deprives litigants of the assurance of impartiality that is the fundamental requirement of due process.

Id. at 831 (Brennan, J., concurring). 
cases in which he has an interest in the outcome."179 As Chief Justice Taft wrote in Tumey:

Every procedure which would offer a possible temptation to the average man . . . to forget the burden of proof required to convict the defendant, or which might lead him not to hold the balance nice, clear and true between the State and the accused, denies the latter due process of law. ${ }^{180}$

179. In re Murchison, 349 U.S. 133, 136 (1955). Under Murchison, it is not necessary to establish that the judge's interest actually altered his or her decision. On the contrary, the relevant inquiry focuses on the "possible temptation" which could lead the judge "not to hold the balance nice, clear and true between the State and the accused." Ward v. Village of Monroeville, 409 U.S. 57, 60 (1972); see also Aetna Life Ins. Co. v. Lavoie, 475 U.S. 813, 825 (1986). Significantly, federal law currently requires a judge to disqualify himself or herself "in any proceeding in which [his or her] impartiality might reasonably be questioned." 28 U.S.C. $\S 455$ (a) (1988). Federal law also requires the disqualification of a judge where, among other things, the judge (1) has "a personal bias or prejudice concerning a party," (2) the judge, a spouse, or a minor child residing in the household has "a financial interest in the subject matter in controversy ... or any other interest that could be substantially affected by the outcome of the proceeding," or (3) the judge or her spouse, or a person within the third degree of relationship to either of them, or the spouse of such a person, is "known by the judge to have an interest that could be substantially affected by the outcome of the proceeding." Id. at $\$ 455(\mathrm{~b})(1)$, (b)(4), (b)(5)(iii). A "financial interest" is statutorily defined as the "ownership of a legal or equitable interest, however small, or a relationship as director, advisor, or other active participant in the affairs of a party." Id. at $\$ 455(\mathrm{~d})(4)$. For an article discussing this federal disqualification statute, see Susan B. Hoekema, Comment, Questioning the Impartiality of Judges: Disqualifying Federal District Court Judges Under 28 U.S.C. $\S 455(a), 60$ TEMP. L.Q. 697 (1987). The Supreme Court in Liljeberg v. Health Services Acquisition Corp. has interpreted 28 U.S.C. $\$ 455$ to require recusal of a judge if a reasonable person, knowing all the circumstances, would expect that a judge would have actual knowledge of his or her interest or bias in the litigation. 468 U.S. 847 (1988); see also id. at 865 ("The very purpose of $\S 455$ (a) is to promote confidence in the judiciary by avoiding even the appearance of impropriety whenever possible."). Although federal law provides for the disqualification of judges under particular circumstances, the Constitution itself may mandate disqualification. See Lavoie, 475 U.S. at 828 ("The Due Process Clause demarks only the outer boundaries of judicial disqualifications. Congress and the states, of course, remain free to impose more rigorous standards for judicial disqualification ....."). Notably, the United States Supreme Court recently heard oral argument in a case alleging that federal judges should be required to disqualify themselves under 28 U.S.C. \$ 455(a) when they might appear to be biased because of their courtroom conduct. Marcia Coyle, High Court Hears Case for Judge's Recusal, NAT'L L.J. (Nov. 15, 1993), at 10 (discussing oral argument in Liteky v. United States, Case No. 92-6921).

180. Tumey, 273 U.S. at 532 (emphasis added); see also Peter David Blanck, et al., Note, The Appearance of Justice: Judges' Verbal and Nonverbal Behavior in Criminal Jury Trials, 38 STAN. L. REv. 89 (1985) (footnotes omitted) (citing supporting case law). 
Likewise, in Ward v. Village of Monroeville, ${ }^{181}$ the Supreme Court invalidated a procedure in which sums produced from a mayor's court accounted for a substantial portion of municipal revenues, even though the mayor's salary was not augmented by those sums. Although the accused in Ward was convicted of only two minor traffic offenses and fined a total of one hundred dollars, the Supreme Court ruled that due process requires the elimination of the possibility of bias. According to the Court:

Plainly [a] "possible temptation" may ... exist when the mayor's executive responsibilities for village finances may make him partisan to maintain the high level of contribution from the mayor's court. This, too, is a "situation in which an official perforce occupies two practically and seriously inconsistent positions, one partisan and the other judicial, [and] necessarily involves a lack of due process of law in the trial of defendants charged with crimes before him."182

Thus, the Supreme Court "may disqualify even decisionmakers who in fact 'have no actual bias' if they might reasonably appear to be biased." 183

Although the Supreme Court has consistently held that judges must be free from the appearance of impropriety, the Supreme Court has also required that other actors in

The trial judge's "appearance," or conduct and behavior, in a criminal jury trial must never indicate to the jury that the judge believes the accused to be guilty. The appearance of bias alone is grounds for reversal even if the trial judge is, in fact, completely impartial. Due process violations have been found when a trial judge's behavior created just the appearance of partiality, and courts have held such behavior sufficient to reverse criminal convictions.

Id. at $89-90$.

181. 409 U.S. 57 (1972).

182. Id. at 60 (quoting Tumey, 273 U.S. at 534).

183. TRIBE, supra note $159, \S 10-16$, at 745 (citing Morrissey v. Brewer, 408 U.S. 471, 485-86 (1972); Goldberg v. Kelly, 397 U.S. 254, 271 (1970)); see also Aetna Life Ins. Co. v. Lavoie, 475 U.S. 813, 825 (1986) ("The Due Process Clause 'may sometimes bar trial judges who have no actual bias and who would do their best to weigh the scales of justice equally between contending parties.'") (quoting Murchison, 349 U.S. at 136); Marshall v. Jerrico, Inc., 446 U.S. 238, 243 (1980) (quoting Offutt v. United States, 348 U.S. 11 (1954) and In re Murchison, 349 U.S. 133 (1955)) ("' $\mathrm{J}]$ ustice must satisfy the appearance of justice," and this 'stringent rule may sometimes bar trial by judges who have no actual bias and who would do their very best to weigh the scales of justice equally between contending parties.'"). 
the criminal justice system remain bias-free. For example, in cases such as Strauder v. West Virginia, ${ }^{184}$ Batson v. Kentucky, ${ }^{185}$ and Taylor v. Louisiana, ${ }^{186}$ the Supreme Court has emphasized that juries must be free of race and gender bias. Likewise, other cases have held that juries must be free of additional biases, misconceptions, and invidious influences. ${ }^{187}$ In Gold v. United States, ${ }^{188}$ the Supreme Court reversed the conviction of an accused who was charged with violating the National Labor Relations Act by filing a false non-Communist affidavit; three members of the Gold jury were approached by an F.B.I. agent and asked if they had received any Communist propaganda. ${ }^{189}$ Likewise, in Carter v. Kentucky, ${ }^{190}$ the Supreme Court held that "[a] state trial judge has the constitutional obligation, upon proper request, to minimize the danger that the jury will give evidentiary weight to the defendant's failure to testify."191

In addition to judges and juries, defense counsel must also be free of influences which might affect a defendant's constitutional rights. Thus, in Glasser v. United States ${ }^{192}$ the

184. 100 U.S. $303(1880)$

185. 476 U.S. 79 (1986) (race-based peremptory challenges are unconstitutional); see also Edmonson v. Leesville Concrete Co., 111 S. Ct. 2077 (1991) (banning race-based strikes by either party in civil litigation); Powers v. Ohio, $111 \mathrm{~S}$. Ct. 1364 (1991) (peremptory challenges cannot be used to exclude jurors not of the same race as the defendant). The Supreme Court is currently considering the question of whether gender-based peremptory challenges are also unconstitutional. Mark Curriden, High Court May Strike Sex-Based Challenges, NAT'L L.J. (Nov. 8, 1993), at 1, 27 (citing J.E.B. v. T.B., No. 92-1239); see also 62 U.S.L.W. 3329 (Nov. 9, 1993) (containing a summary of the oral argument before the Supreme Court in J.E.B. v. T.B.).

186. 419 U.S. 522 (1975).

187. See Remmer v. United States, 350 U.S. 377 (1956).

188. 352 U.S. 985 (1957) (per curiam).

189. "In a criminal case, any private communication, contact, or tampering, directly or indirectly, with a juror during a trial about the matter pending before the jury is deemed presumptively prejudicial, if not made in pursuance of known rules of the court and with full knowledge of the parties." Chester Antieau, Modern Constitutional Law: The Individual and the Government § 5:62, at 348 (1969) (citing Remmer v. United States, 347 U.S. 227 (1954)). As the Supreme Court has firmly stated: "Due process requires a fair trial by an impartial jury free from outside influences." Sheppard v. Maxwell, 384 U.S. 333 (1966).

190. 450 U.S. 288 (1981).

191. Id. at 305 .

192. 315 U.S. 60 (1942). 
Supreme Court held that an attorney's representation of two co-defendants whose interests conflict denies a defendant his constitutional right to effective assistance of counsel. ${ }^{193}$ Another conflict of interest case, Holloway $v$. Arkansas, ${ }^{194}$ is particularly instructive. In Holloway, the defendant's attorney apprised the court of a conflict of interest in his having to represent three co-defendants in the same trial. Holding that an accused's right to counsel was denied where the trial court, over the defense attorney's objection, refused to provide separate counsel for the codefendants, the Supreme Court stated that "whenever a trial court improperly requires joint representation over timely objection reversal is automatic," and no prejudice need be shown. ${ }^{195}$

With significant constitutional rules already prohibiting biased or improperly influenced judges, juries, and defense attorneys, the time has come to end the anachronistic practice of allowing private prosecutors. While the Supreme Court has stated that "[ $\mathrm{t}]$ he rigid requirements of Tumey and Ward, designed for officials performing judicial or quasi-judicial functions, are not applicable to those acting in a prosecutorial or plaintiff-like capacity,"196 it is equally clear that due process requires the imposition of limits on

193. In Glasser, the record indicated that the attorney failed to cross-examine a government witness whose testimony linked Glasser with the conspiracy and failed to object to the admission of arguably inadmissible evidence. Id. at 73-75. This failure was viewed by the Supreme Court as a result of the defense attorney's "struggle to serve two masters." Id. at 75.

194. 435 U.S. 475 (1978).

195. Id. at 488-91; see also Wood v. Georgia, 450 U.S. 261, 271 (1981) (Just as there is a constitutional right to counsel, "there is a correlative right to representation that is free from conflicts of interest.").

To determine the precise degree of prejudice sustained by Glasser as a result of the [district] court's appointment of Stewart as counsel [for the codefendant] is at once difficult and unnecessary. The right to have the assistance of counsel is too fundamental and absolute to allow courts to indulge in nice calculations as to the amount of prejudice arising from its denial.

Glasser, 315 U.S. at 75-76.

196. Marshall, 446 U.S. at 248; see also id. ("The constitutional interests in accurate finding of facts and application of law, and in preserving a fair and open process for decision, are not to the same degree implicated if it is the prosecutor, and not the judge, who is offered an incentive for securing civil penalties."). 
the "partisanship" of prosecutors. ${ }^{197}$ "Prosecutors are also public officials; they too must serve the public interest."198 Thus, although prosecutors need not be entirely "neutral and detached" and are permitted to be "zealous in their enforcement of the law,"199 a prosecutor can be disqualified for participating in litigation in which he or she has a personal interest. ${ }^{200}$ As the Supreme Court has recognized: "A scheme injecting a personal interest, financial or otherwise, into the enforcement process may bring irrelevant or impermissible factors into the prosecutorial decision and in some contexts raise serious constitutional questions."201 Because private prosecutors have financial incentives that public prosecutors do not, and because private prosecutors create, at the very least, an appearance of impropriety, private prosecutors violate defendants' due process rights. As Justice Harlan stated in Mayberry v. Pennsylvania, ${ }^{202}$ "[T] appearance of evenhanded justice . . . is at the core of due process . . .."203

\section{The "Public Interest"}

The "public interest" has always been an elusive concept. It is used by politicians "to justify every engineering brainstorm from the building of massive bridges to the subsidization of lunar visits," 204 and it is used by courts to jus-

197. See Schweiker v. McClure, 456 U.S. 188, 195 (1982) (citations omitted) ("due process demands impartiality on the part of those who function in judicial or quasi-judicial capacities"). Interestingly, the Supreme Court has previously recognized that prosecutors do perform "quasi-judicial" functions. See supra note 131 (citing cases where prosecutors have been given a "quasi-judicial" label).

198. Marshall, 446 U.S. at 249.

199. Id. at 248 (citations omitted).

200. Bordenkircher v. Hayes, 434 U.S. 357 (1978) (federal prosecutor disqualified from participating in litigation in which he has a personal interest).

201. Marshall v. Jerrico, Inc., 446 U.S. 238, 249-50 (1980) (cited in Young, 481 U.S. at 787, 808 \& n.19); see also Aetna Life Ins. Co. v. Lavoie, 475 U.S. 813 (1986) (a state supreme court's affirmance of a damage award was vacated where a justice on the state's highest court with a similar suit pending in a lower state court had cast an apparently decisive vote).

202. 400 U.S. 455 (1971).

203. Id. at 469 (Harlan, J., concurring).

204. Amy Klobuchar, UnCovering the Dome xviii (1982) [hereinafter KLOBUChAR]. 
tify the appropriateness of injunctive relief. ${ }^{205}$ Although one commentator has noted that "[i]t has become fashionable in some quarters to dismiss the concept of the 'public interest' as devoid of content," 206 it is helpful to analyze this concept to determine the constitutionality of private prosecutors because of the requirement that prosecutors serve the "public interest." 207

205. See generally 11 Wright \& Miller, Federal Practice and ProceDURE, $\S 2948$, at 430-31 (1973) (listing the "public interest" as one of four factors for a court to consider in determining the propriety of granting a preliminary injunction). Thus, "[i]t frequently has been emphasized that whether the public interest either might be furthered or might be injured by an injunction should be given considerable weight." Id. at 457 (footnote omitted) (citing Yakus v. United States, 321 U.S. 414 (1944); Hecht Co. v. Bowles, 321 U.S. 321 (1944); Inland Steel Co. v. United States, 306 U.S. 153 (1939)).

206. Brian Barry, Political Argument 207 (1965).

207. Marshall v. Jerrico, Inc., 446 U.S. 238, 249 (1980) (prosecutors "must serve the public interest"); Young, 481 U.S. at 804 ("The prosecutor is appointed solely to pursue the public interest in the vindication of the court's authority."); Town of Newton v. Rumery, 480 U.S. 386, 395 n.5 (1987) ("[T]he constituency of an elected prosecutor is the public, and such a prosecutor is likely to be influenced primarily by the general public interest."); see also Haney v. State, 850 P.2d 1087, 1092 (Okla. 1993) ("[A] district attorney represents the public interest, not the interests of private individuals."); Cantrell v. Commonwealth, 329 S.E.2d 22, 26 (Va. 1985), cert. denied, 496 U.S. 911 (1990) ("[I]t is as much the duty of a Commonwealth's Attorney to protect his fellow citizens from unjustified prosecutions as it is to prosecute the guilty. His duty is 'to seek justice, not merely to convict.' "); $c f$. MODEL CODE of Professional Responsibiltry EC 8-4 (1981) (when "the lawyer purports to act on behalf of the public, he should espouse only those changes which he conscientiously believes [are] in the public interest"). A comment to Standard 3-2.1 of the ABA Standards for Criminal Justice states as follows:

The idea that the criminal law, unlike other branches of the law such as contracts and property, is designed to vindicate public rather than private interests is now firmly established. The participation of a responsible public officer in the decision to prosecute and in the prosecution of the charge gives greater assurance that the rights of the accused will be respected.

ABA Standards for Criminal Justice, Standard 3-2.1 cmt. (1979).

A former United States Attorney, Kenneth Melilli, has reiterated the notion that a prosecutor's role is to serve the public interest. "Prosecutors do not have individual, identifiable clients. They are lawyers for the state. As such, prosecutors represent the public interest. Prosecutors represent the interests of society as a whole, including the interests of defendants as members of that society." Kenneth J. Melilli, Prosecutorial Discretion in an Adversay System, 1992 B.Y.U. L. Rev. 669, 698 (1992) (footnotes omitted) [hereinafter Melilli]; see also W.J. Michael Cody, Special Ethical Duties for Attorneys Who Hold Public Positions, 23 MEM. ST. U. L. REv. 453, 456 (1993) (footnote omitted) ("A prosecutor's duty . . is not to seek convictions, but to seek justice."); Carol Corrigan, On Prosecutorial Ethics, 13 HAsTINGS Const. L.Q. 537, 537-38 (1986) ("[T]he prosecutor represents society as a whole. His goal is truth and the achievement of a just result."). For an article dis- 
However, before the concept of the "public interest" can be applied in the private prosecutor context, at least three complimentary definitions of the concept must be explored. According to one political theorist, Brian Barry, the "public interest" should be defined as those interests which people have in common as members of the public. ${ }^{208}$ This definition is consistent with the views of Rousseau, who believed that government must serve the shared interests of the people and that "it is on the basis of this common interest alone that society must be governed."209 According to another theorist, Jeremy Bentham, the "public interest" should be defined as "the sum of the interests of the several members of the community who compose it." 210 Under this definition, if "most voters favor a certain tax limitation (i.e. the Proposition 13 in California), then its adoption coincides with the public interest."211 A final conception of the "public interest" is provided by Richard

cussing the concept of the "public interest" as it relates to government lawyers, see Nolan, supra note 60, at 36-43. Cf. id. at 42 ("The government lawyer has obligations to the public interest as well as to the mission of her agency. The fact that the government lawyer takes instruction from those invested with policy making powers does not mean that she does so in the service of the agency without regard to the agency's obligations to the public.").

208. Brian Barry, Political Argument 190 (1965). In this regard, Barry makes a distinction between the "public interest" and the "common interest." In recapping Barry's work, one scholar has articulated the distinction as follows:

The common interest is simply an interest shared between individuals. Legal academics have a common interest in a good pay settlement for university teachers, even though we may each gain different amounts. The public interest is used to describe where the net interests which people have qua member of the public or the community. It is this idea of public interest as an interest in our role as members of the community which is perhaps the key to seeing public interest as a subspecies of arguments about the collective welfare. In this way, "the public interest is simply the class of human interests of any group of human beings where the unity of the group is determined by its organization under a common public authority."

John Bell, Public Interest: Policy or Principle?, in Law and the Public InTERest 30 (Proceedings of the 1992 ALSP Conference) (Roger Brownsword ed.) (1993).

Thus, "public interest emerges as a set of fundamental values in society." Id.

209. Jean JacQues Rousseau, Social Contract, Book II, at 23 (1947); see also Brady v. Maryland, 373 U.S. 83, 87 (1963) ("[s]ociety wins not only when the guilty are convicted but when criminal trials are fair").

210. Jeremy Bentham, An Introduction to the Principles of Morals AND LegisLation 3 (1948).

211. Klobuchar, supra note 204 , at xviii. 
Flathman, whose essay describes the public interest as a moral concept judged by values such as "promote justice" or "maximize human freedom." 212 This view originates with Aristotle, who wrote that " $[t]$ he good in the sphere of politics is justice, and justice consists in what tends to promote the common interest." 213

Under the first and third definitions of "public interest," members of the public have an undeniable common interest in receiving fair treatment from the criminal justice system. ${ }^{214}$ Indeed, because any given individual can be accused falsely of a crime, each individual in the society has a common interest in receiving "just" treatment by the prosecuting authority. ${ }^{215}$ This situation is especially true given prosecutors' exercise of almost unbridled discretion. Because of the common community interest in ensuring that

212. Richard E. Flathman, The Public Interest: An Essay Concerning the Normative Discourse of Politics 67 (1966).

213. Aristotle, The Politics of Aristotle 1282b (1962).

214. The Supreme Court has specifically recognized "[ $t]$ he public interest in the accuracy and justice of criminal results." Standefer v. United States, 447 U.S. 10, 25 (1980) (quoting United States v. Standefer, 610 F.2d 1076, 1093 (3d Cir. 1979)). In fact, the Supreme Court has held that the Fourth Amendment's prohibition of unreasonable searches and seizures was designed to protect the "common interest" of the community against unlawful invasion of the home. Miller v. United States, 357 U.S. 301, 313 (1958); see also Gannett Co., Inc. v. DePasquale, 443 U.S. 368, 383 (1979) (noting "public interest" in seeing that justice is "fairly administered," and noting the "great public interest" in having a criminal case heard by a jury); Arizona v. Washington, 434 U.S. 497,510 \& n.27 (1978) (recognizing the "public interest" in "fair judgments" and "just judgments").

215. According to the Supreme Court:

[T] he use of the reasonable-doubt standard is indispensable to command the respect and confidence of the community in applications of the criminal law. It is critical that the moral force of the criminal law not be diluted by a standard of proof that leaves people in doubt whether innocent men are being condemned. It is also important in our free society that every individual going about his ordinary affairs have confidence that his government cannot adjudge him guilty of a criminal offense without convincing a proper factfinder of his guilt with utmost certainty.

In re Winship, 397 U.S. 358, 364 (1970).

See also Strunk v. United States, 412 U.S. 434, 439 n.2 (1973) (Where a unanimous Court held that dismissal of criminal charges was the only possible remedy for denying the defendant a speedy trial, the Court stated that " $[t]$ he public interest in a broad sense, as well as the constitutional guarantee, command prompt disposition of criminal charges."); Mooney v. Holohan, 294 U.S. 103, 112 (1935) (the due process requirement "in safeguarding the liberty of the citizen against deprivation through the action of the State, embodies the fundamental conceptions of justice which lie at the base of our civil and political institutions"). 
prosecutors treat members of the public fairly, the "public interest" demands that the use of private prosecutors, who by definition consider private interests, be prohibited under the due process guarantee.

Significantly, it could be argued, under the second formulation of "public interest," that state statutes permitting the use of private prosecutors merely express the public's interest in allowing each member of the public to hire a private prosecutor if desired. However, this argument is meritless for at least three reasons. First, the use of private prosecutors does nothing to advance the cohesion or development of the community. ${ }^{216}$ On the contrary, the use of such prosecutors pits private citizen against private citizen. ${ }^{217}$ Second, the use of private prosecutors does not further the public interest in obtaining truth or justice, because the use of private prosecutors creates incentives that undermine the pursuit of these goals. For instance, private prosecutors have an incentive to err on the side of their private clients when deciding what exculpatory material to give to a defendant. ${ }^{218}$ Finally, the argument carries no weight because the use of private prosecutors affects constitutional rights that can only be delineated by courts. ${ }^{219}$ Thus, while

216. See supra note 208.

217. The Supreme Court has stated that "the purpose of a criminal court is not to provide a forum for the ascertainment of private rights. Rather it is to vindicate the public interest in the enforcement of the criminal law while at the same time safeguarding the rights of the individual defendant." Standefer v. United States, 447 U.S. 10, 25 (1980) (quoting United States v. Standefer, 610 F.2d 1076, 1093 (3d Cir. 1979)).

218. The "public interest" is greatly disserved if the wrong person is convicted. According to Justice Brennan, "[a] miscarriage of justice that imprisons an innocent accused also leaves a guilty party at large, a continuing threat to society." Richmond Newspapers, Inc. v. Virginia, 448 U.S. 555, 596 (1980) (Brennan, J. concurring).

219. See Bivens v. Six Unknown Named Agents of Fed. Bureau of Narcotics, 403 U.S. 388, 398, 407 (1971) (Harlan, J., concurring) ("[T]he Bill of Rights is particularly intended to vindicate the interests of the individual in the face of the popular will as express in legislative majorities ...."). As Justice Harlan stated in another case:

Legislatures are, as this Court has often acknowledged, the "main guardian" of the public interest, and, within their constitutional competence, their understanding of that interest must be accepted as "well-nigh" conclusive. This principle does not, however, reach all the questions essential to the resolution of this case. The legislative judgments at issue here embrace assessments of the necessity and wisdom of procedural guarantees; these are questions which the Constitution has entrusted at least in part to 
it is normally proper for a legislature to declare the public interest via statute, it is well established that courts must invalidate statutes that disregard constitutional rights. ${ }^{220}$ In this regard, only constitutional provisions, not statutory directives, can ever be deemed the ultimate expression of the public interest for purposes of constitutional interpretation. ${ }^{221}$ Indeed, it must be emphasized that "the purpose of the due process clause-and indeed, of the entire Bill of Rights-is to protect the individual against the government."222 As the Supreme Court stated in In re Gault, ${ }^{223}$

courts, and upon which courts have been understood to possess particular competence.

In re Gault, 387 U.S. 1, 70 (1967) (Harlan, J., concurring in part and dissenting in part) (citation omitted).

220. Under the positivist view of procedural due process, courts have no role to play in defining what procedures are necessary to satisfy the Constitution. "Rather, the term 'due process' dictates that individuals be afforded whatever procedures the legislature has mandated-no more and no less." Redish \& Marshall, supra note 159 , at 457 . Although the first Supreme Court case construing the "due process" clause rejected this view, the positivist approach has been advocated by some members of the Court, including Chief Justice Rehnquist. Compare Murray's Lessee v. Hoboken Land and Improvement Co., 59 U.S. (18 How.) 272, 276 (1855) ("It is manifest that it was not left to the legislative power to enact any process which might be devised. The article is a restraint on the legislative as well as on the executive and judicial powers of the government, and cannot be so construed as to leave congress free to make any process 'due process of law' by its mere will.") with Cleveland Bd. of Educ. v. Loudermill, 470 U.S. 532, 561 (1985) (Rehnquist, J., dissenting) (the Court "ought to recognize the totality of the State's definition of the property right"). However, the positivist approach-which would effectively "rubber stamp" all legislative enactments-has been thoroughly discredited. Redish \& Marshall, supra note 159 , at 456 ("[T]he historical evidence upon which the positivists rely offers no real support for any particular conception of the clause, even if one accepts the controversial principle that modern constitutional interpretation is rigidly controlled by the intent of the framers."); see also id. at 457-68 (outlining the flaws in the positivist approach and demonstrating, both historically and analytically, why courts must determine how much "due process" is constitutionally required).

221. For example, in Llewelyn v. Oakland County Prosecutor's Office, a federal district court granted a movie exhibitor's motion for a preliminary injunction against a county attorney who had been seizing copies of a film and making arrests on the basis of a zoning ordinance that prohibited the exhibition of obscene films within 1,000 feet of a residence. 402 F. Supp. 1379 (E.D. Mich. 1975). In so ruling, the court stated that the First Amendment precluded the court from finding that the "public interest" would be harmed by the showing of a film yet to be found obscene because "it may be assumed that the Constitution is the ultimate expression of the public interest." Id. at 1393.

222. Redish \& Marshall, supra note 159, at 493 (emphasis added).

223. 387 U.S. 1 (1967). In Gault, the Court held that Arizona's juvenile delinquency process denied a juvenile due process of law. 
"Due process of law is the primary and indispensable foundation of individual freedom. It is the basic and essential term in the social compact which defines the rights of the individual and delimits the powers which the state may exercise."224

The notion that a prosecutor's obligation is to further the public interest, rather than private vengeance, is reinforced by the Supreme Court's decision in Imbler $v$. Pachtman. ${ }^{225}$ In Imbler, the Supreme Court held that a public prosecutor has absolute immunity to civil rights actions brought pursuant to 42 U.S.C. $\S 1983 .{ }^{226}$ Thus, in rejecting the contention that prosecutors should enjoy only qualified immunity, the Court stated as follows:

A prosecutor is duty bound to exercise his best judgment both in deciding which suits to bring and in conducting them in court. The public trust of the prosecutor's office would suffer if he were constrained in making every decision by the consequences in terms of his own potential liability in a suit for damages. ${ }^{227}$

As the Court stated later in Imbler: "[Q]ualifying a prosecutor's immunity would disserve the broader public inter-

224. Id. at 20 (footnote omitted); see also Cleveland Bd. of Educ. v. Loudermill, 470 U.S. at 541 ("The right to due process 'is conferred, not by legislative grace, but by constitutional guarantee ....'”) (quoting Arnett v. Kennedy, 416 U.S. 134, 167 (1974) (Powell, J., concurring in part and concurring in result in part)).

225. 424 U.S. 409 (1976).

226. Title 42 U.S.C $\$ 1983$, originally enacted as $\S 1$ of the Civil Rights Act of 1871,17 Stat. 13 , reads as follows:

Every person who, under color of any statute, ordinance, regulation, custom, or usage, of any State or Territory, subjects, or causes to be subjected, any citizen of the United States or other person within the jurisdiction thereof to the deprivation of any rights, privileges, or immunities secured by the Constitution and laws, shall be liable to the party injured in an action at law, suit in equity, or other proper proceeding for redress.

Significantly, federal prosecutors are also absolutely immune from civil suit for constitutional violations. Butz v. Economou, 438 U.S. 478 (1978). But see Burns v. Reed, 111 S. Ct. 1934 (1991) (prosecutors have only qualified immunity when sued for constitutional violations arising out of legal advice given to police). Judges have immunity under Pierson v. Ray, 386 U.S. 547 (1967).

227. Imbler, 424 U.S. at $424-25$. As the Court further stated: "The affording of only a qualified immunity to the prosecutor also could have an adverse effect upon the functioning of the criminal justice system. Attaining the system's goal of accurately determining guilt or innocence requires that both the prosecution and the defense have wide discretion in the conduct of the trial and the presentation of evidence." Id. at 426 (footnote omitted). 
est. It would prevent the vigorous and fearless performance of the prosecutor's duty that is essential to the proper functioning of the criminal justice system."228 In holding that a public prosecutor enjoys absolute immunity from $\S 1983$ actions, the Court also reiterated the "well settled" common law rule that a public prosecutor is absolutely immune from suits for malicious prosecution. ${ }^{229}$ According to the Court:

The common-law immunity of a prosecutor is based upon the same considerations that underlie the common-law immunities of judges and grand jurors acting within the scope of their duties. These include concern that harassment by unfounded litigation would cause a deflection of the prosecutor's energies from his public duties, and the possibility that he would shade his decisions instead of exercising the independence of judgment required by his public trust. ${ }^{230}$

While the public has a separate interest in effective law enforcement, ${ }^{231}$ this interest cannot be advanced at the expense of individual rights. ${ }^{232}$ For example, several members of the Supreme Court have noted that criminal entrapment is not "countenanced" because the "obligation" to avoid "enforcement of the law by lawless means ... goes beyond the conviction of the particular defendant before the court. Public confidence in the fair and honorable administration

228. Id. at 427-28 (footnote omitted).

229. Id. at 424; see also Yaselli v. Goff, 275 U.S. 503 (1927) (per curiam) (affirming a decision of the U.S. Court of Appeals for the Second Circuit that a special assistant to the Attorney General of the United States is absolutely immune from a civil action for malicious prosecution).

230. Imbler, 424 U.S. at $422-23$ (footnote omitted); see also Gannett Co., Inc. v. DePasquale, 443 U.S. $368,384 \mathrm{n} .12$ (1979) ("The responsibility of the prosecutor as a representative of the public surely encompasses a duty to protect the societal interest in an open trial. But this responsibility also requires him to be sensitive to the due process rights of a defendant to a fair trial.").

231. United States v. Ross, 456 U.S. 798, 804 (1982) (noting the "public interest in effective law enforcement").

232. See Gibson v. Florida Legislative Investigation Comm., 372 U.S. 539, 566 (1963) (Douglas, J., concurring) ("'The public interest in the suppression of crime, for example, cannot be weighed against a constitutional provision that accused persons may not be denied the right to counsel.') (quoting Laurent Frantz, The First Amendment in the Balance, 71 YALE L.J. 1424, 1441 (1962)). 
of justice ... is the transcending value at stake."233 Indeed, the Supreme Court has recognized that conflict of interest provisions are "designed to prohibit government officials from engaging in conduct that might be inimical to the best interests of the general public." 234

\section{Conviction Reliability and Prosecutorial Accountability}

In the United States, prosecutors have broad discretion in determining which cases to prosecute. ${ }^{235}$ Prosecutors also enjoy almost unlimited discretion in deciding who and when to investigate, ${ }^{236}$ what offense to be charged, ${ }^{237}$ the timing of an indictment or complaint, ${ }^{238}$ and determining the place of trial. ${ }^{239}$ Because prosecutors have such wide discretion, prosecutorial misconduct is an obvious concern and is, in fact, a significant problem in the criminal justice

233. Richmond Newspapers, Inc. v. Virginia, 448 U.S. 555, 594 n.19 (1980) (Brennan, J., concurring) (citing Sherman v. United States, 356 U.S. 369, 380 (1958) (Frankfurter, J., concurring in result)).

234. United States v. Mississippi Valley Generating Co., 364 U.S. 520, 548 (1961). Because public prosecutors, unlike private prosecutors, have absolute immunity from suit and are therefore free to advance the positions that they believe are in the public interest, prohibiting private prosecutors will undoubtedly further the public interest. Cf. Butz v. Economou, 438 U.S. 478 (1978); Imbler v. Pachtman, 424 U.S. 409 (1976).

235. Garrett v. United States, 471 U.S. 773 (1985); Wayte v. United States, 470 U.S. 598 (1985); see also Melilli, supra note 207, at 672 (footnotes and citations omitted) ("In exercising the charging function, the prosecutor enjoys broad, indeed virtually unlimited, discretion. Indeed, the prosecutor has been fairly described 'as the single most powerful figure in the administration of criminal justice." ).

236. United States v. Martinez, 785 F.2d 663 (9th Cir. 1986).

237. Ball v. United States, 470 U.S. 856 (1985).

238. United States v. Lovasco, 431 U.S. 783 (1977).

239. United States v. Bagnell, 679 F.2d 826 (11th Cir. 1982), cert. denied, 460 U.S. 1047 (1983). In addition, prosecutors have the discretion to arrest, plea bargain, grant immunity, and make bail and sentencing recommendations. Katherine Lowe, Project, Twenty-Second Annual Review of Criminal Procedure: United States Supreme Court and Courts of Appeal 1991-1992, 81 GEO. L.J. 853, 1029-32 (1993). Because most of these decisions are made outside the courtroom, very little of the prosecutor's discretionary authority is subject to judicial supervision. Indeed, it is well-settled that judicial deference "to a prosecutor's broad discretion to initiate and conduct criminal prosecutions" is generally guided by "the recognition that the decision to prosecute is particularly ill-suited to judicial review." Id. at 1029 (citing Wayte v. United States, 470 U.S. 598, 607 (1985) and Town of Newton v. Rumery, 480 U.S. 386, 396 (1987)). 
system. ${ }^{240}$ Given the fact that misconduct does occur among public prosecutors, whose sworn duty is to serve "justice" and the "public interest," the potential for misconduct among private prosecutors, whose salaries are being paid by interested parties, is of particular concern. ${ }^{241}$

In other areas of the criminal justice system, the Supreme Court has attempted to maximize the reliability of criminal convictions. ${ }^{242}$ For example, in In re Winship, ${ }^{243}$ the Supreme Court held that due process requires the prosecution to prove every element of the crime charged "beyond a reasonable doubt." 244 According to the Court: "The reasonable-doubt standard plays a vital role in the American scheme of criminal procedure. It is a prime instrument for reducing the risk of convictions resting on factual error." ${ }^{245}$ Likewise, in Strickland $v$. Washington, ${ }^{246}$ the

240. See Michael T. Fisher, Note, Harmless Error, Prosecutorial Misconduct, and Due Process: There's More to Due Process Than the Bottom Line, 88 Colum. L. REv. 1298, 1322 (1988) (citations omitted) ("Courts and commentators have expressed frustration and concern over the frequent occurrence of prosecutorial misconduct."); see also Albert W. Alschuler, Courtroom Misconduct by Prosecutors and Trial Judges, 50 Tex. L. Rev. 629 (1972).

241. One historian has argued for a return to a system of private prosecution based upon the principle of "self-government." STEINBERG, supra note 11, at 114, 223; see also id. at 230 ("The world of private prosecution ... was relatively democratic, flexible, expandable, and familiar."). However, that same historian details the corruption, misconduct, and abuses inherent in such a system. See Gerald Caplan, Criminal Justice in the Lower Courts: A Study in Continuity, $89 \mathrm{MrcH}$. L. REv. 1694, 1703 (1991) (footnote omitted) (Steinberg's "examples evidence garden variety judicial misconduct-impulsive, arbitrary, biased, and no cause for nostalgia or romantic reminiscences about revitalizing democracy in twentieth-century America. Even to an ardent populist, to one highly suspicious of lawyers, the power of citizen prosecutors to 'define crime' would be unacceptable.") (reviewing Steinberg's book) (citing STEINBERG, supra note 11, at 1, 26, 56, 61, 77, 106, 230); see also Caplan, supra, at 1694 (Steinberg's study of private prosecution in nineteenth-century Philadelphia provides "an unsettling account-an unpleasant reminder of the misconduct and bias which have plagued the administration of justice throughout this nation's history."); STEinBerg, supra note 11, at 47 (some private prosecutions were "manipulative"); id. at 230 (stating that the system of private prosecution was "corrupt, easily manipulated, harsh, and sometimes even cruel").

242. Discovering truth is the primary function of the adversary system. United States v. Havens, 446 U.S. 620 (1980).

243. 397 U.S. 358 (1970).

244. Id. at 364 .

245. Id. at 363 .

246. 466 U.S. 668 (1984). To prove an "ineffective assistance of counsel" claim, the Supreme Court has held that a defendant must show that counsel's performance 
Supreme Court held that a defendant must not receive "ineffective assistance of counsel." In so holding, the Supreme Court emphasized the importance of reliable convictions: "The bench-mark for judging any claim of ineffectiveness must be whether counsel's conduct so undermined the proper functioning of the adversarial process that the trial cannot be relied on as having produced a just result."247 Similarly, in Taylor v. Louisiana, ${ }^{248}$ the Court held that a defendant's constitutional rights were violated by the exclusion of women from the jury pool because the jury venire must be composed of a "fair cross section of the community" in order to ensure the fairness of a defendant's conviction. ${ }^{249}$ Finally, in cases such as Tumey, the Supreme Court has repeatedly held that considerations of fairness dictate

was deficient and that the deficient performance prejudiced the defense. $I d$. at 687 ; see also Hill v. Lockhart, 474 U.S. 52 (1985) (same). Significantly, the requirement that prejudice be shown to establish an "ineffective assistance" claim does not lead to the conclusion that prejudice also has to be shown to reverse a conviction obtained by a private prosecutor. First, whereas prejudice is required with respect to ineffective assistance claims because the government has no control over defense counsel's errors, Strickland, 466 U.S. at 693, it is prosecutorial conduct that is at stake in the private prosecutor context. Second, while ineffective assistance claims do not involve conflict of interest issues, the use of private prosecutors directly implicates such concerns. Indeed, under Cuyler v. Sullivan, 446 U.S. 335 (1980), prejudice to a defendant is presumed if it is demonstrated that defense counsel "actively represented conflicting interests" and that "an actual conflict of interest adversely affected" the lawyer's performance. Id. at 348, 350; see also Burger v. Kemp, 483 U.S. 776, 783 (1987) (same); Strickland, 466 U.S. at 692 (conflicts of interest affecting counsel's performance are presumptively prejudicial). Because prosecutors, in representing the public interest, have an affirmative obligation to represent the interests of a defendant as a member of the general public, private prosecutors are presumptively prejudicial to defendant's rights under Cuyler because they actively represent conflicting interests. Finally, unlike ineffective assistance claims, where the Supreme Court is concerned with whether defense counsel's performance was actually deficient, the mere appearance of impropriety is the critical concern in evaluating the propriety of private prosecutors.

247. Strickland, 466 U.S. at 686 . The Strickland Court stated that " $[t]$ he purpose of the Sixth Amendment guarantee of counsel is to ensure that a defendant has the assistance necessary to justify reliance on the outcome of the proceeding." Id. at 691 92.

248. 419 U.S. 522 (1975).

249. The right of a defendant to challenge prospective jurors for cause to ensure an impartial jury is also well established. Lewis v. United States, 146 U.S. 370 (1892). 
that potentially biased judges not be allowed to sit in judgment. ${ }^{250}$

The notion that fair procedure is critical to the truthseeking function of the adversary system was specifically recognized by the Supreme Court in In re Gault. ${ }^{251}$ In Gault, a majority of the Court stated as follows:

"The history of American freedom is, in no small measure, the history of procedure." But in addition, the procedural rules which have been fashioned from the generality of due process are our best instruments for the distillation and evaluation of essential facts from the conflicting welter of data that life and our adversary methods present. It is these instruments of due process which enhance the possibility that truth will emerge from the confrontation of opposing versions and conflicting data. "Procedure is to law what 'scientific method' is to science." 252

Thus, to ensure the reliability of criminal convictions, the use of private prosecutors must be strictly prohibited. Such prosecutors have strong incentives to please their private clients, and consequently, the potential for prosecutorial misconduct is particularly high. Specifically, private prosecutors may charge an accused inappropriately, fail to deliver complete Brady materials, seek a harsher punishment than is deserved, or engage in misconduct at trial. Because the discretion of prosecutors is virtually unchecked and nearly impossible to monitor, the only way to ensure the reliability of convictions is to prohibit the use of private prosecutors. ${ }^{253}$

Significantly, the use of private prosecutors also undermines prosecutorial accountability. Although two scholars have mused, in a conclusory fashion, that private enforcement of criminal laws against murder or fraud "might be

250. Tumey, 273 U.S. at 532.

251. 387 U.S. 1 (1967).

252. Id. at 21 (footnotes and citations omitted).

253. See Fuentes v. Shevin, 407 U.S. 67, 97 (1972) (due process is required to minimize "substantially unfair or mistaken deprivations"); TRIBE, supra note 159 , $\S 10-7$, at 667 (same). 
salutary," 254 even these scholars concede that the use of public prosecutors increases prosecutorial accountability. According to their recent article:

Executive branch control over federal criminal law enforcement permits greater discretionary enforcement and greater accountability. In a world of limited resources, prosecutorial discretion allows the government to gauge the relative seriousness of particular crimes and the relative threat posed by individual criminals. Few would equate sound policy with the maximum enforcement authorized by law, even if sufficient funds existed. A decision not to enforce may represent as significant a policy determination as one to enforce. Moreover, accountability concerns suggest that the individual making such determinations be subject to the political process. Accountability benefits not only the public as a whole, but the criminally accused whose very liberty is at stake.

The shortcomings of exclusive private enforcement-which have always existed-have . . . become more glaring with the growth of the country and of federal criminal law. For instance, there is little reason to entrust private citizens with the prosecution of victimless crimes like drug use or gambling. Even for crimes with identified victims such as murder or theft, centralized enforcement may well generate benefits. The potential for harassment is minimized through the process of publicly controlled prosecutions. Furthermore, public prosecutors can temper justice with mercy, and only a centralized executive can modulate enforcement of the laws as social conditions change. If the President devotes too few resources to combatting drug use or insider trading, he or she is responsible at election time for decisions to enforce as well as not to enforce. $^{255}$

254. Harold J. Krent \& Ethan G. Shenkman, Of Citizen Suits and Citizen Sunstein, 91 MICH. L. REv. 1793, 1803 (1993) [hereinafter Krent \& Shenkman].

255. Id. at 1803 (footnotes omitted); see also id. at $1803 \mathrm{n} .37$ ("Because only the sovereign can deprive a citizen of liberty, the need for accountability in criminal prosecution is probably greater than in the civil context. The concern for accountability might explain in part the evolution toward public prosecution."); see also Evan Caminker, Comment, The Constitutionality of Qui Tam Actions, 99 Y ALE L.J. 341, 
As a theoretical matter, the concept of prosecutorial accountability strongly militates against the use of private prosecutors. In fact, if a private prosecution is botched, the doctrine of double jeopardy greatly reduces prosecutorial accountability because the government cannot re-prosecute an individual after an acquittal is obtained. ${ }^{256}$ Thus, while public prosecutors are directly accountable to the electorate when a prosecution goes awry, elected prosecutors are only indirectly accountable - to the extent they did not appropriately supervise a prosecution-for the conduct of private prosecutors.

\section{E. From "Supervisory Authority" in Young to the Constitutional Preclusion of Private Prosecutors}

In Young, the Supreme Court relied on its supervisory authority in issuing its ruling "to avoid the necessity of reaching any constitutional issues."257 Obviously, this approach does not preclude and probably only foreshadows a constitutional bar with respect to the use of private prosecutors. Indeed, although some lower courts have used their "supervisory powers" to prohibit private prosecutors, ${ }^{258}$ other lower courts already have held that the practice violates due process. For example, in Brotherhood of Locomotive Firemen \& Enginemen $v$. United States, ${ }^{259}$ the appointment of an interested prosecutor was characterized as a due process violation by the Fifth Circuit. Likewise, in Ganger v. Peyton, ${ }^{260}$ the Fourth Circuit ruled that a due process violation existed where a part-time prosecutor was prosecuting a man for assaulting his wife while simultaneously representing the wife in a divorce proceeding. ${ }^{261}$

368 (1989) ("[B]ecause prosecutors within the executive branch are accountable to the President and, through her, ultimately to the people, they are presumably less likely to enforce the law oppressively or overzealously.").

256. Krent \& Shenkman, supra note 254, at 1804 n.40.

257. Young, 481 U.S. at 809 n.21.

258. Polo Fashion, Inc. v. Stock Buyers Int'l, Inc., 760 F.2d 698 (6th Cir. 1985), cert. denied, 482 U.S. 905 (1987).

259. 411 F.2d 312, 319 (5th Cir. 1969) (cited in Young, 481 U.S. at 808 n.19).

260. 379 F.2d 709 (4th Cir. 1967).

261. Id. at 714-15; see also Cantrell v. Commonwealth, 329 S.E.2d 22, 26 (Va. 1985), cert. denied, 496 U.S. 911 (1990) (citing Ganger) (a private prosecutor having a civil interest in the case so infects the prosecution with the possibility that "private 
The notion that the use of the Supreme Court's "supervisory powers" in Young merely foreshadows a constitutional preclusion of private prosecutors is supported by several Supreme Court rulings. Thus, the Supreme Court has repeatedly exercised its supervisory authority with respect to a given issue prior to creating a due process right in connection with that issue. For example, in United States $v$. Hale, ${ }^{262}$ the Supreme Court exercised its supervisory power to reverse a conviction based on a defendant's silence after being given Miranda warnings. Subsequently, in Doyle $v$. Ohio, ${ }^{263}$ the Court adopted the right to remain silent as a due process right. Likewise, in Offutt $v$. United States, ${ }^{264}$ the Supreme Court, pursuant to its supervisory authority, reversed a criminal contempt conviction on the grounds of judicial bias. Just a year later, in In re Murchison, ${ }^{265}$ the Supreme Court held that conducting a criminal contempt trial before a personally affronted judge violates due process. $^{266}$

The Supreme Court's pattern of using its supervisory authority with respect to a given issue before adopting a due process right with regard to that issue was recognized by the Minnesota Supreme Court in Peterson v. Peterson. ${ }^{267}$ In Peterson, the Minnesota Supreme Court held that state courts may not impose sentences greater than six months for contempt unless a jury trial has occurred or been waived. In so holding, the Peterson court anticipated that the Supreme Court's "supervisory authority" decision in Cheff v. Schnackenberg ${ }^{268}$ was likely to be extended to a constitutional rule and applied to the states through the

vengeance has been substituted for impartial application of the criminal law, that prejudice to the defendant need not be shown"); id. at 27 (harmless error analysis inapplicable).

262. 422 U.S. 13 (1975).

263. 426 U.S. 610 (1976)

264. 348 U.S. 11 (1954).

265. 349 U.S. 133 (1955).

266. Accord Kent v. United States, 383 U.S. 541 (1966) (the Court stated that certain minimum due process protections apply to juveniles tried under the Juvenile Court Act, without explicitly adopting them as due process rights); In re Gault, 387 U.S. 1 (1967) (due process clause applies to juvenile delinquency hearings).

267. 153 N.W.2d 825, 828 n.3 (Minn. 1967).

268. 384 U.S. 373 (1966). 
Fourteenth Amendment. According to the Peterson court: "It is realistic to think that the United States Supreme Court's new rule, although now stated to be in the exercise of its supervisory power, may be extended to the Sixth Amendment of the Federal Constitution and made applicable to the states under the Fourteenth Amendment."269 In fact, the Cheff holding, based upon the Supreme Court's supervisory authority, was later made a due process right. ${ }^{270}$

Both the Fifth and Fourteenth Amendments prohibit the government from depriving an individual "of life, liberty, or property, without due process of law."271 "[T]hese procedural safeguards have their historical origins in the notion that conditions of personal freedom can be preserved only when there is some institutional check on arbitrary government action."272 Indeed, in Marshall v. Jerrico, Inc., ${ }^{273}$ the U.S. Supreme Court stated that the due process guarantee "entitles a person to an impartial and disinterested tribunal in both civil and criminal cases."274 This requirement of neutrality was said to safeguard the two central concerns of procedural due process: "the prevention of unjustified or mistaken deprivations and the promotion of participation and dialogue by affected individuals in the decision making process." 275 As the Supreme Court further emphasized in Marshall:

The neutrality requirement helps to guarantee that life, liberty, or property will not be taken on the basis of an erroneous or distorted conception of the facts or the law. At the same time, it preserves both the appearance and reality of fairness, "generating the feeling, so important to a popular government, that justice has been done," by ensuring that no person will be deprived of his interests in the absence of a proceeding in which he

269. Peterson, 153 N.W.2d at 828.

270. Compare Cheff v. Schnackenberg, 384 U.S. 373 (1966) (establishing a right to a jury trial for nonpetty contempts under the Court's supervisory authority) with Bloom v. Illinois, 391 U.S. 194 (1968) (the right to a jury trial was adopted as a due process right).

271. U.S. Const. amend. V; U.S. Const. amend. XIV, § 1.

272. TRIBE, supra note $159, \S 10-7$, at 664 .

273. 446 U.S. 238 (1980).

274. Id. at 242 .

275. Id. (citing Carey v. Piphus, 435 U.S. 247, 259-62, 266-67 (1978)). 
may present his case with assurance that the arbiter is not predisposed to find against him. ${ }^{276}$

Thus, an "essential safeguard" of due process is the participation of an "independent adjudicator." 277 This is so because the purpose of due process is to ensure the most accurate decision possible, with protections like notice, hearing, right to counsel, and cross-examination all contributing to that goal. ${ }^{278}$ Because of the heavy emphasis the American system of justice places upon the accuracy of results, especially in criminal cases, ${ }^{279}$ an appearance of fairness is also extremely vital to due process. ${ }^{280}$ As the Supreme Court has repeatedly stated: "justice must satisfy the appearance of justice."281. The appearance of fairness value is so critical to due process because it "generate[s] the

276. Id. at 242 (citations omitted) (quoting Joint Anti-Fascist Committee v. McGrath, 341 U.S. 123, 172 (1951) (Frankfurter, J., concurring)).

277. Redish \& Marshall, supra note 159, at 475 ("It is our position that the participation of an independent adjudicator is such an essential safeguard, and may be the only one."); id. at 477 ("the use of an 'independent' adjudicator is a sine qua non of procedural due process"). According to Redish and Marshall:

Review of historical evidence demonstrates that the right to an independent adjudicator was considered a crucial element of procedural justice by the common law, by those that established the law of the colonies, and, perhaps most important, by the Framers of the United States Constitution. This historically fundamental role adds significant weight to the conclusion that the right to an independent adjudicator constitutes the floor of due process.

Id. at 479.

278. Id. at 476.

279. See In re Winship, 397 U.S. 358 (1970) (due process requires that the prosecution prove the guilt of the defendant "beyond a reasonable doubt").

280. According to Beth Nolan:

Justice requires the appearance of justice for the same reason that conflictfree representation requires the appearance of conflict-free representation: in both cases, those outside the process must believe that the process is fair. It is a question of confidence in government. The appearance standard accepts that seeing is believing: if the public sees the process as unjust, or unfair, it cannot be expected to believe otherwise.

Nolan, supra note 60, at 55-56 (footnote omitted); see also David Harris, The Appearance of Justice: Court TV, Conventional Television, and Public Understanding of the Criminal Justice System, 35 ARIz. L. Rev. 785, 790 (1993) (footnote omitted) ("[T]he appearance of justice will affect public perception of the system's legitimacy. A system consistently seen as unjust will eventually lose the allegiance of its citizens. If people perceive the courts as less than fair decision makers, the moral force courts depend on to ensure compliance with decisions they make diminishes.").

281. E.g., In re Murchison, 349 U.S. 133, 136 (1955); Offutt v. United States, 348 U.S. 11, 14 (1954). 
feeling, so important to a popular government, that justice has been done."282

Because fairness and the perception of fairness have always been integral aspects of due process analysis, ${ }^{283}$ Martin Redish and Lawrence Marshall have rightfully recognized that the "mechanical" balancing approach of Mathews "runs counter to the purpose and function" of the due process clauses. ${ }^{284}$ Thus "the due process clauses were devised as protections of individual rights, and must not be subordinated to government interests that are short of overwhelming."285 According to Redish and Marshall:

We have been unable to envision even one situation in which the values of due process can be achieved without the participation of an independent adjudicator. Moreover, in defining the term "independence," even the slightest hint of bias or undue influence must, as a general matter, disqualify a particular decision maker. Only when it is all but impossible to rectify bias should a potential lack of independence be tolerated. ${ }^{286}$

Because prosecutors are such major participants in the criminal justice system, the values of due process require that prosecutors be independent adjudicators. Indeed, because private prosecutions are already so rare, ${ }^{287}$ and be-

282. Joint Anti-Fascist Refugee Committee v. McGrath, 341 U.S. 123, 171-72 (1951) (Frankfurter, J., concurring).

Of all the values informing the due process guarantee, the perception-of-

fairness value most clearly dictates use of a truly independent adjudicator. Whether or not it can be proven that a particular decision maker allows her personal interests to sway her resolution of a dispute, the perception-offairness value demands that she be enjoined from deciding the case if she has some identifiable potential bias. Few situations more severely threaten trust in the judicial process than the perception that a litigant never had a chance because the decision maker may have owed the other side special favors.

Redish \& Marshall, supra note 159, at 483.

283. See John Nowak, Ronald Rotunda \& J. Nelson Young, Constitu. TIONAL LAw 557 (2d ed. 1983) (stating the essential guarantee of due process is fairness).

284. Redish \& Marshall, supra note 159, at 504.

285. Id.

286. Id. (footnote omitted).

287. Stumbo v. Seabold, 704 F.2d 910, 911 (6th Cir. 1983) (noting that private prosecutor statutes are "rarely used"); see also WolfRAM, supra note $129, \S 13.10 .1$, at 759 (noting that a few jurisdictions continue to allow the "barbaric" practice of private prosecutions). 
cause prosecutorial bias can be easily eliminated by prohibiting private prosecutors, due process requires that private prosecutors for interested parties be eliminated.

Under Mathews v. Eldridge, ${ }^{288}$ a court is directed to consider the value of the individual's interest, the risk of erroneous deprivation, and the government interest at stake, including the expense and administrative burden of different procedures. ${ }^{289}$ In assessing the constitutionality of private prosecutors, even under the "mechanical" balancing approach of Mathews, the conclusion is inescapable that the use of private prosecutors violates due process. First, it is unquestionable that an individual has an important stake in not being prosecuted by an interested prosecutor. As the Supreme Court stated in Young:

Between the private life of the citizen and the public glare of criminal accusation stands the prosecutor. That state official has the power to employ the full machinery of the state in scrutinizing any given individual. Even if a defendant is ultimately acquitted, forced immersion in criminal investigation and adjudication is a wrenching disruption of everyday life. For this reason, we must have assurance that those who would wield this power will be guided solely by their sense of public responsibility for the attainment of justice. ${ }^{290}$

That an individual has an important interest in not being erroneously deprived of liberty was reiterated in In re Winship, ${ }^{291}$ where the Supreme Court held that due process requires that a prosecutor prove each element of a crime "beyond a reasonable doubt." According to the Court: "The accused during a criminal prosecution has at stake interests of immense importance, both because of the possi-

288. 424 U.S. 319 (1976).

289. Id . at 335. While the Mathews test is usually applied in civil cases, it has also been used to test the sufficiency of criminal procedures. Ake v. Oklahoma, 470 U.S. 68, 77-82 (1985) (applying Mathews test and holding that an indigent defendant is entitled to access to a psychiatrist if the defendant's sanity is a significant factor); see also United States v. Raddatz, 447 U.S. 667, 677-81 (1980) (applying test to right to de novo hearing of suppression motion); Wofford v. Wainwright, 748 F.2d 1505, 1507-08 (11th Cir. 1984); Shepard v. United States Bd. of Parole, 541 F.2d 322, 32629 (2d Cir. 1976).

290. Young, 481 U.S. at 814.

291. 397 U.S. 358 (1970). 
bility that he may lose his liberty upon conviction and because of the certainty that he would be stigmatized by the conviction."292

With respect to the second Mathews factor, prosecution by a private prosecutor greatly increases the risk of an erroneous deprivation of individual liberty. Because private prosecutors are employed by-and receive compensation from-interested parties, the use of such prosecutors allows influences other than "justice" or the "public interest" to enter into prosecutorial decisions. Thus, the use of private prosecutors not only increases the risk that exculpatory evidence will be withheld from defendants, but the use of such prosecutors greatly increases the risk that an accused will be treated unfairly throughout the criminal process.

Finally, against the highly significant factors of the individual's interest and the risk of erroneous deprivation, the third Mathews factor requires that the government's interest be considered. In particular, Mathews requires a court to consider the expense and administrative burden of different procedures. In balancing this interest, it is clear that the elimination of private prosecutors would only slightly increase a state's expense in administering the criminal justice system. Although private prosecution was once common in the United States, ${ }^{293}$ the use of such prosecutors has become increasingly rare, ${ }^{294}$ with some states having eliminated the practice altogether. In considering the critical interest an individual has in receiving fair treatment from a prosecutor, any additional expense incurred by the state due to the elimination of private prosecutors must be

292. Id. at 363. As the Supreme Court stated in Ake:

The private interest in the accuracy of a criminal proceeding that places an individual's life or liberty at risk is almost uniquely compelling. Indeed, the host of safeguards fashioned by this Court over the years to diminish the risk of erroneous conviction stands as a testament to that concern.

Ake, 470 U.S. at 78.

293. See supra notes 11-29 and accompanying text.

294. See supra note 287. 
deemed insignificant. ${ }^{295}$ Thus, even under Mathews, the use of private prosecutors is unconstitutional.

With respect to the Mathews analysis, two Supreme Court cases decided in the early 1980s, where the Court found no due process violations, are clearly distinguishable. In the first case, Marshall v. Jerrico, Inc., ${ }^{296}$ a constitutional challenge was brought against $\S 16(\mathrm{e})$ of the Fair Labor Standards Act after a restaurant management corporation was assessed civil penalties of $\$ 103,000$ for violations of child labor laws by a regional administrator of the Employment Standards Administration ("ESA") of the Department of Labor. Section 16(e) allowed sums collected as civil penalties for the unlawful employment of child labor to be returned to ESA in reimbursement for the costs of determining violations and assessing penalties. ${ }^{297}$ Although this provision was alleged to create an "impermissible risk and appearance of bias" by encouraging the ESA "to make unduly numerous and large assessments of civil penalties,"298 the Supreme Court rejected this challenge, stating that " $[t]$ he biasing influence ... discern[ed] in $\$ 16(\mathrm{e})$ is ... too remote and insubstantial to violate the constitutional constraints applicable to the decisions of an administrator performing prosecutorial functions." 299

In so holding, the Supreme Court in Marshall noted that no official's salary is affected by the levels of the penal-

295. "[T]he Court has had occasion to recall even recently that "procedural due process is not intended to promote efficiency' and that a procedural safeguard must be afforded 'if that may be done without prohibitive cost.'" TRIBE, supra note 159, $\S 10-13$, at 717 (quoting Fuentes v. Shevin, 407 U.S. 67, 90 n.22 (1972) and Goss v. Lopez, 419 U.S. 565, 580 (1975) (emphasis added)). In Ake, the Supreme Court held that indigent criminal defendants must be provided access to a psychiatrist if insanity is likely to be a significant issue at trial or if the state presents psychiatric testimony of the defendant's future dangerousness at a capital sentencing proceeding. In so holding, the Supreme Court rejected the argument that providing such assistance would result in a "staggering burden" to the State of Oklahoma. Ake, 470 U.S. at 78. According to the Court: "In such a circumstance, where the potential accuracy of the jury's determination is so dramatically enhanced, and where the interests of the individual and the state in an accurate proceeding are substantial, the State's interest in its fisc must yield." Id. at 83.

296. 446 U.S. 238 (1980).

297. Id. at 239.

298. Id. at 241 .

299. Id. at 243-44. 
ties and that the sums collected as child labor penalties amounted to substantially less than one percent of ESA's annual budget. ${ }^{300}$ Furthermore, the Supreme Court emphasized that ESA never spent its full congressional appropriation, and that sums not spent were actually returned to the Treasury.$^{301}$ Finally, aside from noting that civil penalties were never allotted to regional offices on the basis of the total amounts of penalties collected by particular offices, ${ }^{302}$ the Court emphasized that it is ultimately an administrative law judge, not a regional administrator of the ESA, who performs the function of adjudicating child labor violations. ${ }^{303}$ The Supreme Court concluded as follows:

[W]e need not say with precision what limits there may be on a financial or personal interest of one who performs a prosecutorial function, for here the influence alleged to impose bias is exceptionally remote. No government official stands to profit economically from vigorous enforcement of the child labor provisions of the Act. The salary of the assistant regional administrator is fixed by law. The pressures relied on in such cases as Tumey $v$. Ohio are entirely absent here. ${ }^{304}$

Thus, "'[u]nder a realistic appraisal of psychological tendencies and human weakness," 305 the Supreme Court held that it was "exceedingly improbable" that the assistant regional administrator's enforcement decisions would be "distorted" by improper influences or bias. ${ }^{306}$

In the second case, Schweiker v. McClure, ${ }^{307}$ the Supreme Court also rejected a due process challenge to the

300. Id. at $245 \&$ n.6.

301. Id. at 246. The amounts returned to the Treasury substantially exceeded the sums collected under $\S 16(\mathrm{e})$ in all relevant years. $I d$. at 246 (footnote omitted).

302. Id.

303. Id. at 248. Administrative law judges perform de novo review of ESA assessments, and administrative law judges were not entitled to reimbursement in conjunction with $\S 16(\mathrm{e})$. Id . at 245,248 n.10.

304. Id. at 250 (footnote and citations omitted). According to the Supreme Court: "[W]e need not say whether different considerations might be held to apply if the alleged biasing influence contributed to prosecutions against particular persons, rather than to a general zealousness in the enforcement process." Id. at 250 n.12.

305. Id. at 252 (quoting Withrow v. Larkin, 421 U.S. 35, 47 (1975)).

306. Id. at 252 .

307. 456 U.S. 188 (1982). 
system of providing federal reimbursements to insurance carriers under a Medicare provision providing medical insurance benefits. Under the challenged scheme, Congress authorized the Secretary of Health and Human Services to contract with private insurance carriers to administer the payment of qualifying claims. While the Secretary pays the carriers' costs of claims administration, the carriers, in turn, act as the Secretary's agents. If a carrier determines that a claim meets certain criteria, the carrier pays the claim out of a government trust fund. On the other hand, if a carrier denies a claim, the claimant is entitled to a "review determination," whereby the claimant can submit arguments of fact and law and written evidence. Claimants involved in a dispute that is $\$ 100$ or more are entitled to an oral hearing presided over by an officer, chosen by the carrier, who has not participated personally in the case prior to the hearing stage. The hearing officer's decision is not appealable. ${ }^{308}$

At the trial level, a federal judge in California ruled that these hearing procedures violated the constitutional guarantee to due process because of the risk of erroneous deprivation of Medicare benefits created by the carriers' hearing officers' "prior involvement and pecuniary interest." ${ }^{09}$ The district court also held that due process required additional procedural protection, with the trial court ordering that a de novo hearing of record was required before an administrative law judge of the Social Security Administration. In rejecting these holdings, the Supreme Court refused to rely on the district court's "generalized assumptions of possible interest," which placed "special weight on the various connections of the hearing officers with the private insurance carriers." 310 In the words of the Supreme Court:

The difficulty with this reasoning is that these connections would be relevant only if the carriers themselves are biased or interested. We find no basis in the record for reaching such a conclusion .... [T] he carriers pay all . . claims from federal, and not their own, funds.

308. Id. at 190 .

309. Id. at 192.

310. Id. at 196 (footnote omitted). 
Similarly, the salaries of the hearing officers are paid by the Federal Government. Further, the carriers operate under contracts that require compliance with standards prescribed by the statute and the Secretary. In the absence of proof of financial interest on the part of the carriers, there is no basis for assuming a derivative bias among their hearing officers. ${ }^{311}$

Thus, in reconsidering the three factors weighed by the trial court as required by Mathews $v$. Eldridge, ${ }^{312}$ the Court in Schweiker found that no showing was made that the procedures prescribed by Congress and the Secretary were unfair. ${ }^{313}$

Unlike the situations in Marshall and Schweiker, an attorney hired by a victim or a victim's family has a direct financial incentive to further the client's real or perceived interests and to do exactly as the client desires. This incentive exists because the monetary success of private lawyers or law firms depends, in large part, upon the business of current clients or referrals from those clients. ${ }^{314}$ Thus, if a private prosecutor's client does not believe that a case is being vigorously prosecuted (or, more significantly, if the private prosecutor does not "win" the case), the dissatisfied client may simply hire another attorney to prosecute the case or will not use or recommend the private prosecutor in the future..$^{315}$ As a result, "under a realistic appraisal of psychological tendencies and human weakness"- to use the

311. Id. at 196-97 (citations and footnote omitted).

312. 424 U.S. 319 (1976). See supra notes 167-69 and accompanying text (containing a discussion of the three Mathews factors).

313. Schweiker, 456 U.S. at 200.

314. Sally J. Schmidt, Selling Your Lawyers On Client Surveys, The AmERICAN Lawyer Management SeRv. (1990-2000 ed.), vol. 1, at 10.17 (research shows that a firm's current clients can be responsible for up to $80 \%$ of its business through ongoing work or referrals); Ronald M. Martin, The Empowered Law Firm, PracticING LAw INST. (Total Quality Management for Law Firms 1993: Turning Awareness Into Action), available in WESTLAW, TP-ALL Database (July-Sept. 1993) (60\% of a lawyer's new business comes from the recommendation of current or former clients) [hereinafter Martin].

315. Client loyalty to lawyers and law firms has significantly declined in recent times because of the increasing supply of lawyers and legal services. See Martin, supra note 314 ("There is now what the economists call a 'mature market' where there is low demand because there is an enormous supply of lawyers. This has eroded client loyalty and given the clients enormous power to determine how and in what ways legal services will be delivered."). 
language of Marshall-it is not "exceedingly improbable" that significant decisions made by a private prosecutor will be "distorted" by the pressures created by his or her individual client. ${ }^{316}$ Indeed, because a private prosecutor's interest in obtaining a conviction is anything but remote, ${ }^{317}$

316. Private clients often have great influence over their attorneys. For example, courts have recognized that payment of fees by a client can affect a lawyer's loyalties. See Wood v. Georgia, 450 U.S. 261, 268-69 (1981) ("Courts and commentators have recognized the inherent dangers that arise when a criminal defendant is represented by a lawyer hired and paid by a third party, particularly when the third party is the operator of the alleged criminal enterprise."); see also supra note 315 (describing how client loyalty has declined in recent times); Nolan, supra note 60, at 52 ("The human-nature rationale for regulation of potential conflicts of interest accepts that the ability of individuals to rise above their conflicting loyalties (even when it is theoretically possible to do so) is limited."). In Wood, an attorney, paid by the employer, represented two employees in a criminal prosecution for distributing obscene material. Under those facts, the Court held that the record was unclear "whether counsel was influenced in his basic strategic decisions by the interests of the employer who hired him," although the record did demonstrate at least the "possibility of a conflict of interest." Wood, 450 U.S. at 272. Consequently, the Court remanded for a determination, pursuant to the due process guarantee, as to whether the employees' convictions were tainted by an attorney's conflict of interest. Id. at 273-74.

317. The Supreme Court has stated that some interests are so "minute, remote, trifling or insignificant" that they do not create due process violations. See Tumey, 273 U.S. at 532; see also Aetna Life Ins. Co. v. Lavoie, 475 U.S. 813 (1986) (noting that a judge's interest that was "highly speculative and contingent" would not violate due process). Although the Supreme Court stated in dicta in Commonwealth Coatings v. Continental Casualty Co. that Tumey required a decision to be set aside where "the slightest pecuniary interest" existed, the Supreme Court has since declined to read Tumey "as constitutionalizing any rule that a decision rendered by a judge with 'the slightest pecuniary interest' constitutes a violation of the Due Process Clause." Commonwealth Coatings v. Continental Casualty Co., 393 U.S. 145, 148 (1968); Lavoie, 475 U.S. at 825 n.3. Because of the strong financial incentives that private prosecutors have to obtain convictions, such prosecutors do not implicate merely "minute" or "remote" interests. As the Supreme Court stated in Tumey:

The mayor received for his fees and costs in the present case $\$ 12$, and from such costs under the prohibition act for seven months he made about $\$ 100$ a month, in addition to his salary. We can not regard the prospect of receipt or loss of such an emolument in each case as a minute, remote, trifling or insignificant interest. It is certainly not fair to each defendant brought before the mayor for the careful and judicial consideration of his guilt or innocence that the prospect of such a prospective loss by the mayor should weigh against his acquittal.

Id. at 531-32. 
the due process clause prohibits the use of private prosecutors. ${ }^{318}$

In Young, the Supreme Court noted that "the fact that the judge makes the initial decision that a contempt prosecution should proceed is not sufficient to quell concern that prosecution by an interested party may be influenced by improper motives." 319 The Court stated the following:

A prosecutor exercises considerable discretion in matters such as the determination of which persons should be targets of investigation, what methods of investigation should be used, what information will be sought as evidence, which persons should be charged with what offenses, which persons should be utilized as witnesses, whether to enter into plea bargains and the terms on which they will be established, and whether any individuals should be granted immunity. These decisions, critical to the conduct of the prosecution, are all made outside the supervision of the court. ${ }^{320}$

In light of the enormous discretionary powers that prosecutors wield, the prosecutorial function cannot be entrusted to private counsel representing purely private interests.

The significance of this principle is best illustrated in the context of states that retain capital punishment. In such states, because prosecutors make the charging and plea bargaining decisions, it is literally true that the life or death of an accused could rest in the hands of a private prosecutor. In light of vengeful desires that victims' families frequently feel, private prosecutors will often experience pressure from victims' families not to plea bargain and to seek the death penalty. In fact, because attorneys have an ethical

318. See Blackledge v. Perry, 417 U.S. 21, 28-29 (1974) (due process requires that the "potential for vindictiveness" not enter into prosecutorial decisions). Under Article III of the Constitution, "[t]he Judges, both of the supreme and inferior courts, shall hold their offices during good behavior, and shall, at stated Times, receive for their Services a Compensation, which shall not be diminished during their Continuance in Office." U.S. CoNST. art. III, $\S 1$. The salary provisions of Article III, designed to protect the judiciary's independence, were based on the conclusion that "[i]n the general course of human nature, a power over a man's subsistence amounts to a power over his will." THE FEDERALIST No. 79, at 583 (A. Hamilton) (E. Earle ed. 1937); see also Northern Pipeline Constr. Co. v. Marathon Pipe Line Co., 458 U.S. 50 (1982).

319. Young, 481 U.S. at 807.

320. Id. 
obligation to zealously represent their clients' interests, ${ }^{321}$ if a murder victim's family wants the death penalty imposed, a private prosecutor may have an ethical obligation not to plea bargain and to seek the death penalty irrespective of what justice would otherwise require. ${ }^{322}$

In the past, courts have articulated several reasons for retaining the right to employ a private prosecutor. For example, in State v. Atkins, ${ }^{323}$ the West Virginia Supreme Court listed the following reasons for retaining the right to employ a private prosecutor: (1) there may be occasions when the public prosecutor is in need of assistance to carry out her duties effectively; (2) there may be occasions when the employment of a private prosecutor would satisfy the public's concern that a given case not be accorded perfunctory treatment; and (3) the victim's family may wish to satisfy itself that the case is being vigorously prosecuted..$^{324}$ Other stated rationales for retaining the use of private prosecutors include the protection of property rights, ${ }^{325}$ reserv-

321. See Model Rules of Professional Conduct (1983) (preamble) (“As advocate, a lawyer zealously asserts the client's position under the rules of the adversary system."); see also Model Rules of Professional Conduct Rule $1.7 \mathrm{cmt}$. (1983) ("Loyalty is an essential element in the lawyer's relationship to a client."); Model Rules of Professional Conduct Rule 1.2(a) (1983) ("A lawyer shall abide by a client's decisions concerning the objectives of representation ...."); Olson v. Fraase, 421 N.W.2d 820 (N.D. 1988) (an attorney must follow the client's specific instructions); Foothills Dev. Co. v. Clark County Bd., 730 P.2d 1369 (Wash. App. 1986) (an attorney must follow the client's specific instructions). But cf. Model Rules of Professional Conduct Rule $1.2 \mathrm{cmt}$. (1983) ("At the same time, a lawyer is not required to pursue objectives or employ means simply because a client may wish that the lawyer do so.").

322. In states that allow private prosecutors, it is often stated that private prosecutors are bound by the same standards of conduct as public prosecutors, presumably requiring private prosecutors to disregard the wishes of their clients when "justice" or the "public interest" so requires. Aside from the ethical tension that this standard creates (and regardless of whether private prosecutors can actually refuse to honor their clients' wishes), incentives will always exist in close cases to err on the side of a private client, rather than with the accused. This situation is especially true given the subjective nature of "justice" and the "public interest."

323. 261 S.E.2d 55 (W. Va. 1979), cert. denied, 445 U.S. 904 (1980).

324. Id.

325. Handley v. State, 106 So. 692,695 (Ala. 1925). 
ing public prosecution for non-petty offenses, ${ }^{326}$ as well as the saving of time and resources. ${ }^{327}$

Whatever superficial appeal these reasons have had for some courts, none of the reasons outweigh the due process concerns raised by private prosecutors. First, the government's interest in preventing a slight increase in expenditures necessitated by a rule prohibiting private prosecutors pales in comparison to the defendant's interest in not being prosecuted by someone with a conflict of interest. ${ }^{328}$ Indeed, because private prosecutions are already so rare, ${ }^{329}$ justifying the use of such prosecutors on the ground that they save the government's financial resources is a complete ruse. State public defenders' offices have always been more financially overburdened than public prosecutors' offices, ${ }^{330}$ and the general public, acting through its elected

326. People ex rel. Allen v. Citadel Management Co., 355 N.Y.S.2d 976 (N.Y. Crim. Ct. 1974); see also People v. Black, 282 N.Y.S. 197, 201 (Ostego County Ct. 1935) (minor infractions do not necessitate "heavy artillery" of district attorney or Attorney General).

327. See United States v. Crawford Enter., Inc., 643 F. Supp. 370, 380 (S.D. Tex. 1986), order aff'd and appeal dismissed, 826 F.2d 392 (1987) ("To require a government prosecutor to present facts supporting criminal contempt and a private attorney to present facts supporting civil contempt would be an injudicious use of the court's, government's and the private attorney's time and resources."). Because the American system of justice recognizes "higher values than speed and efficiency," the use of private prosecutors, even in the contempt context where such individuals may possess a greater understanding of the underlying facts, is inappropriate. Stanley v. Illinois, 405 U.S. 645, 656 (1972).

328. The fact that prohibiting private prosecutors may produce more intangible benefits while allowing private prosecutors may produce real cost savings, however small those may be, does not preclude a rule barring private prosecutors. According to two scholars:

By their very nature, procedural safeguards impose administrative costs and burdens on the government that would not otherwise exist. At the same time, the benefits of such safeguards are not always immediately recognizable. Often it is not clear that the ultimate outcome in a particular case will be more just or efficient when specific procedures are employed than when they are not. In an important sense, then, the benefits of procedural due process - at least when measured from a purely efficiency standpoint-are prophylactic in nature.

Redish \& Marshall, supra note 159 , at 473 . Significantly, even the use of private prosecutors involves public costs. Thus, in states that allow private prosecutors, public prosecutors are still required to supervise and control the activities of private prosecutors.

329. See supra note 287.

330. Dziubak v. Mott, 503 N.W.2d 771, 775 (Minn. 1993) ("Public Defender offices are grossly under-funded."). According to one law review article, a politician 
representatives or via referendum, is always free to devote additional resources to law enforcement activities.

The argument that private prosecutors are necessary to assist public prosecutors to more vigorously enforce the law must also fail. Once again, the general public is free to devote more financial resources to law enforcement activities if it desires. In fact, the public interest will sometimes demand that certain anachronistic laws, like penal laws prohibiting adultery, actually not be enforced. Conversely, if crimes worthy of more vigorous prosecution, such as child abuse or sexual assaults, are not being appropriately prosecuted by the local district attorney, the lax enforcement can become a campaign issue and the neglectful public prosecutor can be thrown out of office. ${ }^{331}$

\footnotetext{
"at best, has little to gain by advocating large expenditure for the defender office, and at worst, much to lose." Suzanne E. Mounts, Public Defender Programs, Professional Responsibility, and Competent Representation, 1982 WIS. L. REv. 473, 482.

331. Notably, even if a local district attorney refuses to prosecute a worthy case, many state laws already provide the victim or the victim's family with alternate remedies. See generally Sidman, supra note 11, at 764-65, 790 (describing statutes, which exist in a majority of states, that permit the appointment of special temporary prosecutors to be paid with government funds or that authorize courts to appoint counsel to replace the district attorney when he or she fails to perform his or her duties or has an interest in the proceedings); $c f$. ABA Standards for Criminal Justice, Standard 3-2.1 cmt. (1979) ("Private prosecution . . . should be distinguished from the process available in some jurisdictions whereby a private citizen may file a complaint if the prosecutor refuses to act."); ABA Standards for Criminal Justice, Standard 32.10(a) (1979) ("Procedures should be established by appropriate legislation to the end that the governor or other elected state official is empowered by law to suspend and supersede a local prosecutor upon making a public finding, after reasonable notice and hearing, that the prosecutor is incapable of fulfilling the duties of office."); ABA Standards for Criminal Justice, Standard 3-2.10(b) (1979) ("The governor or other elected official should be empowered by law to substitute special counsel in the place of the local prosecutor in a particular case, or category of cases, upon making a public finding that this is required for the protection of the public interest."). For example, in State ex rel. Wild v. Otis, when the elected officials refused to prosecute a case, the Minnesota Supreme Court noted that an aggrieved citizen might (1) petition the district court to appoint a special prosecutor, (2) appeal to the governor, who then might order the Attorney General to commence prosecution, or (3) seek mandamus. 257 N.W.2d 361, 364-65 (Minn. 1977), cert. denied, 434 U.S. 1003 (1978); see also Kentucky v. Hubbard, 777 S.W.2d 882, 885 (Ky. 1989) (Leibson, J., dissenting) (if county attorney is incapable, unable, or unwilling to prosecute, the aggrieved citizen can apply for relief to the "prosecutors advisory council" created by Ky. REv. STAT. $§ 15.705$ (Michie/Bobbs-Merrill 1988)). Under federal law, the U.S. Attorney can appoint a disinterested private attorney to prosecute a case. 28 C.F.R. $\S 45.735-3$ (c) (1993); 28 U.S.C. $\S 543$ (1988).
} 
In prohibiting private prosecutors, victims' rights will not be compromised. Victims or their families may already express their feelings of outrage at the sentencing stage, ${ }^{332}$ and victims, whether of assault, robbery, or otherwise, are free to testify at trial regarding their sense of violation at the hands of the alleged wrongdoer. Although victims' rights are of critical importance, the use of private prosecutors in the name of victims' rights cannot be tolerated. Private prosecutors have significant adverse effects on defendants' constitutional rights, and such prosecutors are completely unnecessary to vindicate the rights of victims.

Finally, contrary to the suggestion that private prosecutors benefit law enforcement activities by providing additional resources, the use of private prosecutors actually creates castes within the criminal justice system. Thus, whereas wealthy citizens can afford to pursue questionable criminal prosecutions by hiring private prosecutors, poor individuals, who are statistically more likely to be racial minorities, ${ }^{333}$ cannot afford access. ${ }^{334}$ In this vein, the

332. Payne v. Tennessee, 111 S. Ct. 2597 (1991) (admission of testimony of murder victim's mother during the sentencing phase of a capital case did not violate the defendant's due process rights); see also Williams v. New York, 337 U.S. 241, 246 (1949) (sentencer has wide discretion in types of information used to determine sentence).

333. The World Almanac and Book of Facts 395 (1993).

334. According to one source:

Under a system of private prosecution, the prosecution of criminal offenses depends upon the ability and willingness of the victim or other interested individuals to bring prosecutions, which the poor and powerless are less able and willing to do. Accordingly, one of the reasons for establishing the office of public prosecutor might have been to ensure that poor victims as well as rich victims would be able to obtain redress for crimes committed against them or their property.

Gittler, supra note 11 , at 130 (footnote omitted). Notably, one historian has argued that private prosecution, at least in nineteenth-century Philadelphia, "represented the dignity and citizenship of Philadelphia's poor and working classes at least as much as it represented their oppression." STEINBERG, supra note 11, at 114. According to Steinberg:

Private prosecution was, for [the citizen litigants of Philadelphia], a democratic form of law enforcement and criminal justice, involving in great numbers citizens of all social and economic groups with state officials who responded directly and personally (if not always satisfactory) to their requests. . . . Through private prosecution, even the poor, many of them disenfranchised, had a stake in the legal and political process, received something palpable from it, and asserted that democracy in America was something special. 
Supreme Court has consistently held that rich and poor alike must be afforded "equal justice" under the Constitution. As Justice Douglas wrote for the Supreme Court in Harper v. Virginia Board of Elections, ${ }^{335}$ where Virginia's poll tax was struck down: "Lines drawn on the basis of wealth or property, like those of race . . . are traditionally disfavored." 336

Although poor individuals have been afforded only "minimal protection" by the Burger and Rehnquist Courts, ${ }^{337}$ the poor have retained special protection within the context of the criminal justice system. For example, in Griffin v. Illinois, ${ }^{338}$ the Supreme Court utilized the equal protection and due process clauses to strike down a law requiring criminal appellants to pay for trial transcripts. As the Supreme Court stated in Griffin: "There can be no equal justice where the kind of trial a man gets depends on the amount of money he has. Destitute defendants must be offered as adequate appellate review as defendants who

Id. at 231.

However, Steinberg's thesis, especially as applied in modern times, has several flaws. First, because modern-day public prosecutors are elected, every citizenwhether rich or poor-already has a responsive official with whom to lodge complaints. Second, because courts are unlikely to allow non-lawyers to assist in bringing criminal prosecutions, the high cost of legal services in modern society precludes the poor, as a practical matter, from hiring private prosecutors. Finally, a system of private prosecution favors the rich, not the poor. Indeed, Steinberg himself acknowledges that the poor, even in nineteenth-century Philadelphia, were sometimes oppressed by the private prosecution system. Id. at 86 ("Bouvier [a Philadelphia court recorder] explicitly accused the poor of being responsible for petty litigation and implied that, if they had not been poor, they would have been like other Americans who brought civil actions against one another. Instead they initiated criminal cases involving themselves, the only objects of value they possessed."); id. at 26 (footnote omitted) ("A newspaper court reporter marveling in 1848 at how "the miserable outcasts of society' race to the alderman's office over their petty quarrels, 'each endeavoring to ... have their opponents arrested before they were taken into custody themselves' and, in so doing, 'expend ... the greatest portion of the money that falls by accident within their grasp." ").

335. 383 U.S. 663 (1966).

336. Id. at 668; see also Edwards v. California, 314 U.S. 160 (1941) (a California law making it a misdemeanor to knowingly bring a non-resident indigent into the state was struck down).

337. See TRIBE, supra note 159, $\$ 16-35$, at 1626 n.4; Bradley R. Hogin, Equal Protection, Democratic Theory, and the Case of the Poor, 21 Rutgers L.J. 1, 39 (1989). Compare Frank I. Michelman, On Protecting the Poor Through the Fourteenth Amendment, 83 HaRv. L. Rev. 7 (1969).

338. 351 U.S. 12 (1956). 
have money enough to buy transcripts." 339 Likewise, in Gideon v. Wainwright, ${ }^{340}$ the Supreme Court held that every indigent criminal defendant accused of a felony is entitled to appointed counsel. The guarantee of appointed counsel was subsequently broadened in Argersinger v. Hamlin ${ }^{341}$ to include all prosecutions which resulted in imprisonment for any term. More recently, the Supreme Court has held that an indigent criminal defendant has a right to the assistance of a psychiatrist at state expense if the defendant's sanity will be a significant factor at trial or if the state presents psychiatric testimony during a capital sentencing proceeding. ${ }^{342}$ As Professor Laurence Tribe has observed: "Particularly noteworthy in all of these cases is the Court's willingness to mandate what amounts to state purchase of private services-legal or medical-for private citizens." ${ }^{343}$

One of the most striking features of public prosecution in the United States is that wealthy and poor individuals alike have equal access, at least theoretically, to the criminal justice system. Thus, while imperfections concededly exist, public prosecutors should treat criminal assaults on welfare recipients as seriously as they treat assaults on white-collar executives. In contrast to this egalitarian system, allowing private prosecutors creates situations in which the criminal justice system treats wealthy individuals better than poor individuals. Because the use of private prosecutors runs contrary to the concept of "equal jus-

339. Id. at 19; see also Evitts v. Lucey, 469 U.S. 387 (1985) (entitling defendants to effective assistance of counsel on first appeal of right); Little v. Streater, 452 U.S. 1 (1981) (state must pay for blood test of indigent defendant in paternity action); Boddie v. Connecticut, 401 U.S. 371 (1971) (requiring indigent to pay court costs to obtain divorce violates due process); Douglas v. California, 372 U.S. 353 (1963) (indigent convicted criminal defendants are entitled to counsel on first appeal of right).

340. 372 U.S. 335 (1963). In Gideon, the Court held that the "noble ideal" of "fair trials before impartial tribunals" cannot be realized "if the poor man charged with crime has to face his accusers without a lawyer to assist him." Id. at 344.

341. 407 U.S. 25 (1972).

342. Ake v. Oklahoma, 470 U.S. 68 (1985). The Ake Court viewed its holding as consistent with "the belief that justice cannot be equal where, simply as a result of his poverty, a defendant is denied the opportunity to participate meaningfully in a judicial proceeding in which his liberty is at stake." Id. at 76.

343. TRIBE, supra note $159, \S 16-40$, at 1635 . 
tice," 344 the Constitution prohibits the use of such prosecutors. $^{345}$

In several cases, courts have noted that private prosecutors are bound by the same standards of professional conduct as public prosecutors. ${ }^{346}$ According to the West Virginia Supreme Court, "[t]his rule blunts, if it does not entirely dissipate, the major criticism of private prosecutors, that they will be overzealous to convict and consequently ignore the public prosecutor's fundamental obligation to do justice." 347 However, what these courts fail to recognize is that private prosecutors cannot possibly adhere to the same standards of professional conduct as public prosecutors; the conflicts of interest that arise for private prosecutors are simply irreconcilable. A private prosecutor, who is being paid handsomely to convict someone, cannot also, without at least some subtle bias, fairly represent the interests of that person and consider the "public interest" in treating that person justly.

In a normal prosecution, a public prosecutor can engage in prosecutorial misconduct by, among other things, pursuing plainly impermissible lines of questioning or argu-

344. The Fourteenth Amendment to the United States Constitution provides that "[n]o state shall ... deny to any person within its jurisdiction the equal protection of the laws." Although the federal government is not governed by the Fourteenth Amendment, an equal protection requirement is also imposed under the Fifth Amendment's due process clause because "it would be unthinkable that the same Constitution would impose a lesser duty on the Federal Government." Bolling v. Sharp, 347 U.S. 497, 500 (1954) (footnote omitted).

345. Tate v. Short, 401 U.S. 395 (1971) (equal protection is violated where punishment is limited to a fine for those able to pay it but is converted to imprisonment for those unable to pay it); Williams v. Illinois, 399 U.S. 235, 244 (1970) (equal protection guarantee requires that maximum term of imprisonment be the same for all defendants regardless of economic status); see also CHRISTOPHER SMITH, COURTS AND THE POOR 12-40, 73-143 (1991) (detailing the lack of access the poor have to the criminal justice system and summarizing Supreme Court precedent in that area).

346. E.g., New Jersey v. Imperiale, 773 F. Supp. 747, 751 n.7 (D. N.J. 1991); Kentucky v. Hubbard, 777 S.W.2d 882, 883-84 (Ky. 1989); Cantrell v. Commonwealth, 329 S.E.2d 22, 25 (Va. 1985), cert. denied, 496 U.S. 911 (1990); Kerns v. Wolverton, 381 S.E.2d 258, 261 (W. Va. 1989); State v. Worley, 369 S.E.2d 706, 718 (W. Va. 1988); Kennedy v. State, 342 S.E.2d 251, 258 (W. Va. 1986); State v. Riser, 294 S.E.2d 461, 465 (W.Va. 1982); State v. Atkins, 261 S.E.2d 55, 58 (W. Va. 1979), cert. denied, 445 U.S. 904 (1980); State ex rel. Moran v. Ziegler, 244 S.E.2d 550 (W. Va. 1978).

347. State v. Atkins, 261 S.E.2d 55, 58 (W. Va. 1980), cert. denied, 445 U.S. 904 (1980) (footnote omitted). 
ment, interrupting defense counsel's examination of witnesses, or acting unfairly toward defense counsel, the accused, or defense witnesses. ${ }^{348}$ Although abolishing private prosecutions will not mean the end of prosecutorial misconduct, the abolition of such prosecutors will at least reduce the number of such incidents. ${ }^{349}$ While public prosecutors may, at times, become overzealous in their desire to obtain a conviction, the Young Court correctly recognized

348. Wolfram, supra note $129, \S 13.10 .4$, at 766 (citations omitted).

349. That private prosecutors engage in misconduct is demonstrated by the case of Hughes v. Bowers. 711 F. Supp. 1574 (N.D. Ga. 1989), aff'd, 896 F.2d 558 (11th Cir. 1990). In Hughes, the defendant was convicted of voluntary manslaughter after a private prosecutor represented to defense counsel that no policies of insurance existed which might serve to impeach one of the state's key witnesses. However, when defense counsel later discovered the existence of an impeaching insurance policy, the defendant's petition for habeas corpus was granted, with the court holding that the participation of a private prosecutor, hired by the victim's family, rendered the defendant's trial fundamentally unfair. In so holding, the court emphasized that the private prosecutor, in addition to participating in the criminal prosecution, also represented a member of the victim's family on a claim brought pursuant to the concealed policy of insurance. The court stated as follows:

An actual conflict of interest arose when the defense moved for production of insurance policies. The special prosecutor had a duty to disclose the policy but had a conflicting interest to conceal it. He chose to conceal it. By any standard, this deliberate, affirmative concealment from the court and the defense of important evidence constitutes a serious act of misbehavior which disregarded the rights of the defendant. The special prosecutor abdicated his duty to seek justice rather than conviction, and Hughes's trial was rendered fundamentally unfair.

Id. at 1584 .

Likewise, in Stumbo v. Seabold, 704 F.2d 910, 912 (6th Cir. 1983) (applying Kentucky law), the Sixth Circuit held that a defendant's trial was rendered fundamentally unfair by a private prosecutor's misconduct in accusing the defendant of a conspiracy that was unsupported by the evidence and in referring to the defendant as "Johnny Murder Boy." Even courts that have approved of the use of private prosecutors have warned of the dangers of overzealous private prosecutors. E.g., State v. Addis, 186 S.E.2d 415, 417 (S.C. 1972) ("We are not unaware of the fact that sometimes private counsel, assisting the solicitor, has a tendency to become eager in the prosecution. It therefore becomes the duty of the trial judge, as well as the solicitor, to be solicitous of defendant's rights, working to the end that defendant's rights be fully protected."); $c f$. State of New Jersey v. Imperiale, 773 F. Supp. 747, 748 (D. N.J. 1991) ("Individuals can and do utilize such criminal proceedings to bolster a related civil proceeding or merely for vindictive or harassing purposes."); New Jersey v. Kinder, 701 F. Supp. 492 (D. N.J. 1988) ("While there is the possibility of frivolous suits and vindictive behavior by some complaints, abuses are checked and deterred by the Court's discretion and by the various other remedies available for malicious prosecution."). 
that this "problem ... is personal, not structural." 350 Unlike the potential personal deficiencies with public prosecutors, the problem created by private prosecutors is structural in nature. Thus, unlike public prosecutors, private prosecutors have additional structural incentives to seek convictions rather than justice. ${ }^{351}$ For example, under Brady v. Maryland $^{352}$ a prosecutor is obligated to provide defense counsel with exculpatory evidence on the issue of either guilt or punishment. The determination before trial of what is material and exculpatory is necessarily left to the prosecutor, and courts rely on prosecutors to exercise their broad discretion responsibly. ${ }^{353}$ Confidence that a prosecutor will exercise judgment responsibly is not possible when there is the presence of a private party's interest in addition to that of doing justice. ${ }^{354}$

350. Young, 481 U.S. at 809 n.18; see also Polo Fashions, Inc. v. Stock Buyers Int'l, Inc., 760 F.2d 698, 705 (1985), cert. denied, 482 U.S. 905 (1987) (In disapproving the use of an interested contempt prosecutor, the court stated that overzealousness "does not have its roots in a conflict of interest. When it manifests itself the courts deal with it on a case-by-case basis as an aberration. This is quite different from approving a practice which would permit the appointment of prosecutors whose undivided loyalty is pledged to a party interested only in a conviction."). The fact that private prosecutors create structural defects in the criminal justice system makes prosecutorial misconduct cases, which require a showing of prejudice, irrelevant. Thus, cases such as Darden v. Wainwright and Donnelly v. DeChristoforo, where the relevant inquiry is "whether the prosecutors' comments so infected the trial with unfairness as to make the resulting conviction a denial of due process," address only situations involving personal misconduct. Darden, 477 U.S. 168, 181 (1986); Donnelly, 416 U.S. 637, 643 (1974).

351. According to one court:

The question of what constitutes an "impartial" prosecutor demands clarification. A prosecutor is not "partial" simply because she zealously seeks conviction. Rather, "partiality" in this context is similar to a conflict of interest in the sense that the prosecutor has a personal interest or stake in the outcome of the criminal prosecution. Thus, "partiality" refers not to "personal" zeal but to "structural" problems where personal interests (including non-pecuniary interests) generate a structural conflict of interest.

New Jersey v. Imperiale, 773 F. Supp. 747, 750 (D. N.J. 1991).

352. 373 U.S. 83 (1963).

353. Cf. United States v. Valenzuela-Bernal, 458 U.S. 858 (1982) (prosecutor has discretion to determine whether illegal aliens may be deported or must be kept in United States to testify at trial).

354. For example, in Hughes v. Bowers, a private prosecutor failed to disclose Brady material, and his prosecutorial misconduct resulted in the defendant's habeas corpus petition being granted. 711 F. Supp. 1574 (N.D. Ga. 1989), affd, 896 F.2d 558 (11th Cir. 1990). 
A federal district court case, United States ex rel. Miller v. Myers, ${ }^{355}$ provides a good illustration of why interested private prosecutors are violative of defendants' due process rights. In that case, a defendant charged with burglary was represented by an attorney who was simultaneously representing the owner of the allegedly burgled establishment in another matter. In reversing the defendant's conviction on the grounds that the conflict of interest violated the defendant's constitutional right to counsel, the court stated that "[i]t takes no great understanding of human nature to realize that the individuals who had been burglarized might be less than happy and might go so far as to remove the attorney from their good graces if this defendant were acquitted." 356

Judge Friendly's opinion in Wright v. United States ${ }^{357}$ supports the notion that the use of private prosecutors should be barred in all circumstances. In Wright, Judge Friendly first stated that the word "disinterested" should describe situations where a prosecutor does not have an interest which constitutes "an additional and impermissible reason in forwarding the prosecution." 358 Because of the practical impossibility of showing that a private prosecutor for an interested party actually prejudiced a defendant, ${ }^{359}$ Judge Friendly then concluded that the mere appearance of impropriety must be sufficient to establish a due process violation. According to his opinion in Wright, "the practical impossibility of establishing that [a prosecutorial conflict of interest] has worked to the defendant's disadvantage dic-

\footnotetext{
355. 253 F. Supp. 55 (E.D. Pa. 1966).

356. Id. at 57.

357. 732 F.2d 1048 (2d Cir. 1984), cert. denied, 469 U.S. 1106 (1985).

358. Id. at $1056 \mathrm{n} .7$.

359. Several courts have held that a defendant's conviction will not be overturned absent a showing that the conduct of a private prosecutor actually "prejudiced" the defendant's trial. See, e.g., Powers v. Hauck, 399 F.2d 322, 325 (5th Cir. 1968) (The use of a special prosecutor is not improper where "the special prosecutor is not guilty of conduct prejudicial to the defendant, and the rights of the defendant are duly observed."); Hughes v. Bowers, 711 F. Supp. 1574 (N.D. Ga. 1989), aff'd, 896 F.2d 558 (11th Cir. 1990) ("To demonstrate a denial of due process, the petitioner . . . must show evidence of specific misbehavior on the part of the prosecutor which prejudiced the defendant."); State v. Cockrell, 309 P.2d 316, 320 (Mont. 1957); State v. Ray, 143 N.E.2d 484, 485 (Ohio Ct. App. 1956).
} 
tates the adoption of standards under which a reasonable potential for prejudice will suffice." 360 Because private prosecutors always have "an additional and impermissible reason" to forward a prosecution, namely, they represent private interests, the mere appearance of impropriety must be sufficient to establish a due process violation. In the Supreme Court's own words, "justice must satisfy the appearance of justice." 361

Indeed, while due process considerations prohibit the use of private prosecutors, civil proceedings provide interested parties with an adequate, and more appropriate, legal remedy. For example, if a murder has occurred, a wrongful death statute will provide an interested party with a forum to seek civil redress, while the due process clause safeguards the rights of the accused in the criminal proceeding. This distinction between criminal and civil liability dictates that private prosecutors be prohibited. According to one commentator:

[O]ur legal system generally considers criminal behavior to be more opprobrious than civil misconduct and criminal sanctions to be both quantitatively and qualitatively more severe than civil sanctions. The structural check against oppressive prosecution in the form of frivolous suits or excessive punishments that is created by executive oversight and discretion ought to be much more stringent in the criminal than the civil context, just as due process safeguards are more stringent against erroneous conviction than erroneous civil liability. ${ }^{362}$

360. Wright, 732 F.2d at 1056.

361. Murchison, 349 U.S. at 136; see also Richmond Newspapers, Inc. v. Virginia, 448 U.S. 555, 571-72 (1980) (quoting Offutt v. United States, 348 U.S. 11, 14 (1954)) ("To work effectively, it is important that society's criminal process 'satisfy the appearance of justice' ....").

362. Evan Caminker, Comment, The Constitutionality of Qui Tam Actions, 99 YALE L.J. 341, 371 (1989) (footnotes omitted) (citing Wayne LaFave \& Austin Scott, Criminal Law 12-16 (2d ed. 1986) (listing distinctions between civil and criminal sanctions) and Hart, The Aims of the Criminal Law, 23 LAW \& Contemp. Pross. 401, 402-06 (1958) (same)) [hereinafter Caminker]; see also Richard Epstein, Crime and Tort: Old Wine in Old Bottles, in Assessing the Criminal 231 (R. Barnett \& J. Hagel eds. 1977) (distinguishing between civil and criminal law). Unlike private prosecutions, qui tam actions are statutorily created and allow a private citizen to receive part of a fine or penalty, usually $50 \%$, for successfully suing a wrongdoer. A qui tam action is not a criminal prosecution; rather, it is a "remedial" 
Even if the Supreme Court refuses to declare the use of private prosecutors unconstitutional in all cases, an interested prosecutor's participation at trial must invalidate any conviction obtained for any serious offense. ${ }^{363}$ Thus, even if private prosecutors are permitted for minor offenses or crimes, it must be a per se violation of a defendant's due process rights when a private prosecutor participates in any proceeding which could result in significant jail time. In this regard, the case of State of New Jersey $v$. Kinder ${ }^{364}$ is particularly instructive. In Kinder, a federal district court in New Jersey held that a municipal court rule allowing a defendant to be prosecuted through the use of a private attorney did not violate the defendant's due process rights, where the defendant was charged with simple assault and battery and, if convicted, would not receive a criminal record or a jail term exceeding six months. ${ }^{365}$ According to the Kinder court:

proceeding that imposes only civil sanctions. United States $e x$ rel. Marcus v. Hess, 317 U.S. 537, 549 (1943); see also Caminker, supra, at 370 ("qui tam lawsuits seek only civil remedies and bring only private enforcement machinery to bear"); $c f$. Robert W. Fischer, Comment, Qui Tam Actions: The Role of the Private Citizen in Law Enforcement, 20 UCLA L. REv. 778, 786 (1973) (footnote omitted) ("The overwhelming weight of authority supports the view that qui tam actions are civil actions."). To the extent any qui tam statutes permit the pursuit of criminal remedies by private parties, such statutes must be declared unconstitutional. $C f$. United States ex rel. Kelly v. Boeing Co., No. 92-36660 (9th Cir. Sept. 7, 1993), 62 U.S.L.W. 2165 (rejecting a due process challenge to a qui tam provision of the False Claims Act, but noting that a criminal prosecution might require a higher level of prosecutorial disinterest than would be necessary in a civil enforcement action under the False Claims Act).

363. It is a well-settled principle of constitutional law that due process rights increase as the consequences of the governmental action to the individual become more severe. See Argersinger v. Hamlin, 407 U.S. 25 (1972) (defendant entitled to legal representation when defendant faces imprisonment); Baldwin v. New York, 399 U.S. 66 (1970) (serious offenses require a trial by jury); Bloom v. Illinois, 391 U.S. 194 (1968) (criminal contempt defendants have the right to a jury trial if the contempt charged is serious); see also 18 U.S.C. § 3172(2) (1985) (statutory right to speedy trial under Speedy Trial Act applies only to serious offenses). A criminal contempt is considered serious if the sentence is for more than six months. Cheff v. Schnackenberg, 384 U.S. 373, 380 (1966).

364. 701 F. Supp. 486 (D. N.J. 1988).

365. See id. at 490 (distinguishing Young on the ground that the defendants in that case were given sentences ranging up to five years); see also id. at 491 ("The United States Supreme Court has itself recognized that the full panoply of procedural protections is not required where lesser charges are involved and minimal pun- 
It is important to emphasize that this is not a case involving an offense arising under federal laws subject to prosecution by federal authorities. Nor is this a prosecution for a felony or misdemeanor which can result in a criminal record, a lengthy jail term and a loss of certain privileges of citizenship. This is not a prosecution for criminal contempt which also involves the possibility of a lengthy jail term in addition to the more concrete conflicts of interest which exist when an attorney prosecutes a person in a criminal matter while simultaneously representing that person's opponent in an underlying civil matter. This is also not a case where the public prosecutor has declined to prosecute the defendant after expressly finding that there is no probable cause for such action. In all of those cases, I have no doubt that a private attorney would be precluded by the United States Constitution . . . from conducting a criminal prosecution. ${ }^{366}$

Because of the "death is different" jurisprudence that has been developed, the use of private prosecutors is particularly inappropriate in cases involving capital crimes. ${ }^{367}$ As

ishment is authorized.") (citing Duncan v. Louisiana, 391 U.S. 145 (1968) (right to jury trial does not apply to crimes with possible punishments of six months or less)).

366. Kinder, $701 \mathrm{~F}$. Supp at 492 (citation omitted) (emphasis added).

367. "Because sentences of death are 'qualitatively different' from prison sentences, this Court has gone to extraordinary measures to ensure that the prisoner sentenced to be executed is afforded process that will guarantee, as much as is humanly possible that the sentence was not imposed out of whim, passion, prejudice, or mistake." Eddings v. Oklahoma, 455 U.S. 104, 117-18 (1982) (O'Connor, J., concurring); see also Saffle v. Parks, 494 U.S. 484, $492-93$ (1990); Whitmore v. Arkansas, 495 U.S. 149, 167 (1990) (Marshall, J., dissenting) ("It is by now axiomatic . . that the unique, irrevocable nature of the death penalty necessitates safeguards not required for other punishments."); Caldwell v. Mississippi, 472 U.S. 320, 329 (1985); California v. Ramos, 463 U.S. 992, 998-99 (1983) ("[T]he qualitative difference of death from all other punishments requires a correspondingly greater degree of scrutiny of the capital sentencing determination.").

Even in the nineteenth century, the propriety of a private attorney prosecuting a capital crime was questioned:

Prominent attorney David Paul Brown's memoirs often refer to criminal cases that were conducted by private counsel. A major concern of his was to advise lawyers to abandon prosecutions if they discovered that they were dishonest and, as a rule, not to prosecute a capital charge- "never take blood money." Brown implied that capital offenses and other "great public wrongs" should be conducted by the public prosecutor ....

STEINBERG, supra note 11 , at 81 .

See also George W. Warvelle, Essays in Legal Ethics (1902): 
Justice Stevens stated in Barclay v. Florida, ${ }^{368}$ "A constant theme of our cases ... has been emphasis on procedural protections that are intended to ensure that the death penalty will be imposed in a consistent, rational manner." 369

\section{CONCLUSION}

In Young v. United States ex rel. Vuitton et Fils S.A., ${ }^{370}$ the United States Supreme Court issued a stern warning in deciding that private attorneys for interested parties could not prosecute criminal contempt actions. Although the Young Court relied on its "supervisory authority" to reach this result, the Supreme Court's decision used broad, sweeping language that makes the opinion resemble a due process ruling. While Justice Blackmun's concurrence in Young was the only vote that would have established a constitutional right to a disinterested prosecutor, the broad language of Justice Brennan's majority opinion in Young strongly suggests that decision merely foreshadows a Supreme Court ruling forbidding the use of private prosecutors in all criminal cases. Therefore, in the wake of Young, state legislatures immediately should abolish the practice of allowing private prosecutors.

It not infrequently happens that private counsel are employed to assist the state. This is now generally regarded as an allowable practice, but for many years an attorney accepting such a retainer, particularly when his fee was paid by private parties, was considered as having violated an ethical canon of the profession. This was always the case when the charge involved a capital crime. "Never take blood money," say the old writers, and if we are to credit the biographies of the ancient worthies they never did. In fact, the old Ciceronian idea seems at one time to have thoroughly pervaded the bar, and numerous admonitions have come down to us that where life or death is the issue, "it is always more honorable to defend than to prosecute."

Id. at 142 (citing Brown's Forum, Vol. 2, p. 40); id. at 143 ("There is something revolting to the moral sense in the spectacle of counsel selling his talents to enable an individual to satisfy his thirst for vengeance, and this, in most cases, is just what counsel does when he accepts a private retainer to assist the prosecuting officer.").

368. 463 U.S. 939 (1983).

369. Id. at 960 (Stevens, J., concurring); see also Godfrey v. Georgia, 446 U.S. 420, 427 (1980) (plurality opinion) ("[T]he penalty of death may not be imposed under sentencing procedures that create a substantial risk that the punishment will be inflicted in an arbitrary and capricious manner.").

370. 481 U.S. 787 (1987). 
On the judicial front, at least until the Supreme Court addresses the constitutional implications of private prosecutors, lower courts should eliminate the use of such prosecutors through constitutional means ${ }^{371}$ or, alternatively, via their "supervisory authority." 372 In particular, state courts should hold that it is a per se violation of a defendant's constitutional rights if a private prosecutor for an interested party participates in any way in the criminal trial of that defendant. ${ }^{373}$ Thus, a private prosecutor should be absolutely prohibited from sitting with the public prosecutor at counsel's table during trial, and should not be allowed to examine witnesses, make objections, conduct opening or closing argument, or engage in courtroom activity of any

371. According to one commentator:

[A] state court might conclude that the appointment of the private, interested attorney does violate fourteenth amendment due process. Arguments for this result are found in the "harmless error" analysis advanced by the Court in Young. Even though the Court's reversal was in reliance upon its supervisory authority to avoid the necessity of reaching the constitutional issues, the Court applied a constitutional standard in deciding that this error could not be considered harmless.

Braswell, supra note 3, at 163 (footnote omitted).

See also id. at 162 ("[A] recent trend in state constitutional law is that state courts are frequently interpreting their respective constitutions to 'guarantee rights that the Supreme Court has held that the federal Constitution does not secure.'") (quoting Barbara Kritchevsy, Justiciability in Tennessee, Part One: Principles and Limits, 15 MEM. Sr. U. L. Rev. 1, 1-2 nn.1-2 (1984)).

372. Young, 481 U.S. at 808 n.18 (court can exercise its inherent supervisory power to disqualify certain individuals from acting as prosecutors); State v. Marshall, 586 A.2d 85 (N.J. 1991) (court can disqualify prosecutor for "nefarious" interest); see Commonwealth v. Hubbard, 777 S.W.2d 882, 885 (Ky. 1989) (Leibson, J., dissenting) ("we should decide whether the proper performance of the supervisory authority entrusted to us by the Kentucky Constitution" requires the elimination of the use of interested private prosecutors). In addition, courts should use their authority to control who appears before them to prohibit the use of private prosecutors. Chambers v. Nasco, 501 U.S. 32 (1991) (courts have inherent authority "to manage their own affairs so as to achieve the orderly and expeditious disposition of cases," including the authority to control who may appear before the court) (citing Link v. Wabash R. Co., 370 U.S. 626, 630-31 (1962)); see also State of New Jersey v. Imperiale, 773 F. Supp. 747, 756 (D. N.J. 1991) (court has inherent authority to control who appears before it); Bartone v. United States, 375 U.S. 52, 54 (1963) (per curiam) (Supreme Court and Courts of Appeals have broad powers of supervision over federal proceedings).

373. As the Supreme Court has previously acknowledged, certain errors may involve "rights so basic to a fair trial that their infraction can never be treated as harmless error." Gideon v. Wainwright, 372 U.S. 335 (1963) (right to counsel); Tumey v. Ohio, 273 U.S. 510 (1927) (impartial judge)). 
kind. ${ }^{374}$ Indeed, because structural problems are created by the possibility that private prosecutors will engage in misconduct or misuse their discretion, ${ }^{375}$ any violation of the rule barring private prosecutors requires the automatic reversal of a defendant's conviction without a showing of prejudice. ${ }^{376}$

With respect to pre-trial activity, courts should also prohibit private attorneys for interested parties from interfering in the criminal process. For example, as the West Virginia Supreme Court held in Kerns v. Wolverton, ${ }^{377}$ a private attorney for an interested party should not be allowed to appear before or participate in a grand jury proceeding. The Kerns court stated that "the presence of a private prosecutor in a grand jury room is inconsistent with the traditional view that the grand jury should be impartial and independent, and thus free of even the possibility that outside pressure or influence will infiltrate the process." 378

374. In Young, the Supreme Court stated in dicta that a private party's attorney's "familiarity" with the underlying facts "may be put to use in assisting a disinterested prosecutor in pursuing the contempt action, but cannot justify permitting counsel for the private party to be in control of the prosecution." Young, 481 U.S. at $807 \mathrm{n} .17$. This language should not be construed to allow an interested party's attorney to participate in a criminal proceeding or prosecute a criminal case, with the only requirement being that the attorney play a subordinate role to that of the public prosecutor. Instead, the "assist" language should be read narrowly, allowing an interested party's attorney only to familiarize the public prosecutor with his or her version of the facts consistent with the party's First Amendment rights. A private attorney should not be allowed to "assist" the public prosecutor with any aspect of the criminal process because of the discretionary and unreviewable nature of prosecutors' work.

375. Obviously, prosecutorial misconduct or the misuse of prosecutorial discretion hinders the discovery of truth, which is the primary function of the court and the fundamental purpose of the adversary system. E.g., United States v. Havens, 446 U.S. 620 (1980).

376. Some constitutional errors create "structural defects in the constitution of the trial mechanism, which defy analysis by 'harmless-error' standards." Arizona v. Fulminante, 499 U.S. 279, 319 (1991). "The existence of such defects-deprivation of the right to counsel, for example-requires automatic reversal of the conviction because they infect the entire trial process." Brecht v. Abrahamson, 61 U.S.L.W. 4335, text accompanying n.4 (1993) (citing Fulminante).

377. 381 S.E.2d 258 (W. Va. 1989).

378. Id. at 262; see id. (footnote omitted) ("Obviously, the presence of a private prosecutor before a grand jury could only serve to enhance the public perception that a grand jury is an instrument controlled by the desires of the prosecution."); 38 AM. JUR. 2d Grand Jury $\$ 35$ (1968) ("The presence and participation in grand jury proceedings of a person assuming the role of a private prosecutor, retained by 
Likewise, courts should find a violation of a defendant's constitutional rights, requiring a retrial, if a private attorney for an interested party participates in anything more than de minimis activities outside the courtroom at the request of the public prosecutor. ${ }^{379}$ This rule recognizes that private attorneys, hired by victims or their families, have incentives, financial or otherwise, to conceal exculpatory evidence that they uncover during the course of a criminal investigation. For example, if a public prosecutor asks a private attorney to investigate some aspect of a crime, the

outside interests for the purpose of obtaining an indictment against particular individuals, is generally considered highly improper."); Nichols v. State, 87 S.E. 817 (Ga. App. 1916) (same); Flege v. State, 142 N.W. 276 (Neb. 1913) (same); Cantrell v. Commonwealth, 329 S.E.2d 22, 25 (Va. 1985) (same).

379. See Kerns v. Wolverton, 381 S.E.2d 258, 262 (W. Va. 1989) ("The participation of a private prosecutor in the pretrial stages of litigation should be viewed with a wary eye, as it is at this point that the public prosecutor exercises 'virtually unchecked and unreviewed discretion' with respect to matters occurring outside of the courtroom."). But cf. Scheldberger v. State, 204 Wis. 235, 235 N.W. 419 (1931) (although private prosecutors are not permitted under Wisconsin law, a private attorney was allowed to take witnesses' statements and do investigatory work). Significantly, the Fourth Amendment freedom from unreasonable searches and seizures by the State does not apply to actions by private individuals. Mapp v. Ohio, 367 U.S. 643 (1961). E.g., United States v. Jacobsen, 466 U.S. 109, 113 (1984); Coolidge v. New Hampshire, 403 U.S. 443 (1971); Burdeau v. McDowell, 256 U.S. 465, 467 (1921); United States v. Andrews, 618 F.2d 646, 648-52 (10th Cir. 1980); United States v. Winbush, 428 F.2d 357, 359 (6th Cir. 1970); People v. Randazzo, 34 Cal. Rptr. 65, 69-71 (Cal. App. 1963); People v. Moreno, 135 Cal. Rptr. 340, 342 (Sup. Ct. 1976); State v. Clark, 454 So. 2d 232, 234-37 (La. App. 1984); District Attorney for Plymouth District, 434 N.E.2d 1276, 1279 (Mass. 1982); Waters v. State, 575 A.2d 1244, 1246 (Md. 1990); State v. Jenkins, 259 N.W.2d 109, 111-12 (Wis. 1977). Accordingly, "when a private individual obtains incriminating matter from an accused, no matter how improperly, and such matter comes into the possession of the government without a violation of the accused's rights by government authority, the exclusionary rule does not prohibit its use at trial." Waters, 575 A.2d at 1246; State v. Von Bulow, 475 A.2d 995, 1012 (R.I. 1984); see also Colorado v. Connelly, 479 U.S. 157, 166 (1986) ("The most outrageous behavior by a private party seeking to secure evidence against a defendant does not make that evidence inadmissible under the Due Process Clause."); State v. Clark, 743 P.2d 822, 826 (Wash. App. 1987). A private search or seizure only triggers Fourth Amendment protections if the private individual whose actions are in question, "in light of all the circumstances of the case, must be regarded as having acted as an 'instrument' or agent of the state." Coolidge, 403 U.S. at 487 . To be an instrument or agent of the state, a private party must be involved directly as a participant in the search or indirectly as an "encourager" or instigator of the private citizen's actions. United States v. Walther, 652 F.2d 788, 791 (9th Cir. 1981); Clark, 743 P.2d at 826. A government may not exceed the scope of a private search unless it has the right to make an independent search. Walter v. United States, 447 U.S. 649, 657 (1980); Von Bulow, 475 A.2d at 1018. 
private attorney may have incentives, because of the association with the interested client, not to turn over exculpatory evidence that is discovered during that investigation. Because the participation of an interested party's attorney in pre-trial activity also creates structural problems with the criminal process, the harmless error rule should not apply to such pre-trial activity. ${ }^{380}$

In the United States, victims and their families are undeniably legitimate participants in the criminal justice system. Victims and their families have a right to observe, monitor, and participate in criminal proceedings, and such individuals must have access to, and communication with, the public prosecutor. However, while victims and their families have many rights, including the ability to testify about the impact of a crime at the sentencing phase, ${ }^{381}$ the constitutional rights of an accused must not be compromised. Criminal prosecutions are the process by which individuals are deprived of their life or liberty. The dire consequences of such prosecutions require that an accused receive due process before any adverse action is taken. By infecting the criminal justice system with impermissible incentives, private prosecutors create structural flaws in the system which violate the Constitution's due process guarantee. Because private prosecutors represent, or, at the very least, are perceived to represent, interests other than "justice" or the "public interest," the use of private prosecutors must be forbidden. In the words of President John F. Kennedy, "the basis of effective government is public confi-

380. A criminal defendant's constitutional rights are not affected by the pre-trial activity of a private attorney who is not acting at the request of a public prosecutor. This rule recognizes that a public prosecutor has no control over private attorneys or private investigators. However, evidence obtained through private means must remain subject to the usual constitutional rules once it is turned over to the prosecutor's office. See Von Bulow, 475 A.2d at 1012 (citation omitted) (when the government significantly expands a prior private search without first procuring a search warrant and no recognized exception to the warrant requirement exists to justify such expansion, the independent governmental search is subject to the proscriptions of the Fourth Amendment).

381. Compare Booth v. Maryland, 482 U.S. 496 (1987) (invalidating a state law providing for victim impact statements at sentencing trials in capital proceedings) with Payne v. Tennessee, 111 S. Ct. 2597 (1991) (overruling Booth and holding that a state has a legitimate interest in presenting relevant victim impact evidence in a capital sentencing proceeding). 
dence, and that confidence is endangered when ethical standards falter or appear to falter." 382 